\title{
EVALUATING ALTERNATIVE HYDRAULIC SOLUTIONS TO LIMIT NUTRIENT CONTAMINATION OF AN AQUIFER IN SOUTHERN CALIFORNIA
}

\author{
A Thesis \\ Presented to \\ The Faculty of California Polytechnic State University, \\ San Luis Obispo
}

\author{
In Partial Fulfillment \\ Of the Requirements for the Degree \\ Master of Science in Civil and Environmental Engineering \\ By \\ Jake Mendoza Perry \\ April 2012
}




\section{(C) 2012 \\ Jake Mendoza Perry \\ ALL RIGHTS RESERVED}




\section{Committee Membership}

TITLE Evaluating Alternative Hydraulic Solutions to

Limit Nutrient Contamination of an Aquifer in Southern California

AUTHOR: Jake Mendoza Perry

DATE SUBMITTED:

April 2012

COMMITTEE CHAIR:

Misgana Muleta, Assistant Professor

COMMITTEE MEMBER:

Trygve Lundquist, Associate Professor

COMMITTEE MEMBER:

Shikha Rahman, Associate Professor 


\title{
Abstract
}

Evaluating Alternative Hydraulic Solutions to Limit Nutrient Contamination of an

\author{
Aquifer in Southern California \\ Jake Mendoza Perry
}

Many small communities depend on groundwater sources for drinking water and they often use septic tanks for their sewer system needs. However, nitrates and other pollutants from septic systems can percolate to the aquifers and deteriorate quality of the groundwater, threatening the public health. This study has developed a groundwater model using Visual MODFLOW for an aquifer that is used as a water supply source for the cities of Beaumont and Cherry Valley, California. Septic systems are the suspected major source of nitrate contamination of the aquifer. The model has been developed to clarify the extent of interactions between nitrate pollutants, infiltration and percolation from a recently established series of artificial recharge ponds, groundwater recharge from natural sources, and pumping activities to meet local water uses. The primary objective of this study is to evaluate alternative hydraulic solutions that would limit the movement of the contaminants and minimize the risk of affecting the pumping wells. The study attempts to identify the best way to recharge the aquifer and influence movement of the nitrates so that polluted waters may have lower nitrate concentrations in the future, rather than allowed to encroach on critical production wells or led away from production wells to become a problem for future generations or neighboring areas. The data needed to build the model, including geological logs, precipitation, evapotranspiration, well locations, pumping schedules, water levels, and nitrate concentrations have been obtained from the Beaumont Cherry Valley Water District. The model has been calibrated to simulate the observed groundwater levels and the extent of pollution corresponding to the historical pumping rates, recharge rates and climate. The calibrated model has been used to evaluate alternative hydraulic solutions that would either localize the nitrate pollution thus limiting the impact on public welfare, or remove the nitrate pollution for potential treatment and remediation on the surface. The study results show that increased pumping of production wells or strategic placement of additional artificial recharge may reduce the concentrations of nitrate in the Beaumont Basin.

Keywords: groundwater, artificial recharge, nitrate, septic tank, groundwater modeling 


\section{Acknowledgements}

I'd like to thank Joseph Reichenberger, Bryan Wilfley, Tony Lara, and everyone at the Beaumont Cherry Valley Water District, as well as Jeff Davis and Cheryle Rasmussen and everyone at the San Gorgonio Pass Water Agency, for their assistance with this thesis.

For their guidance through the development of my thesis, l'd like to thank Dr. Misgana Muleta, Dr. Shikha Rahman, and Dr. Trygve Lundquist.

For all his help with the technical aspects of this project, l'd like to thank Ron Leverett. I literally could not have done this work without his help.

Last, but certainly not least, I would like to thank my family, Steve, Aurora, and Maria Perry. You guys are pretty great at getting me to laugh when models don't converge. 


\section{Table of Contents}

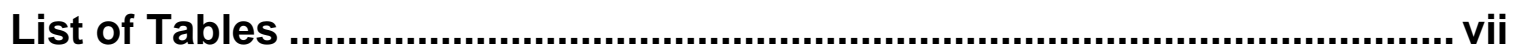

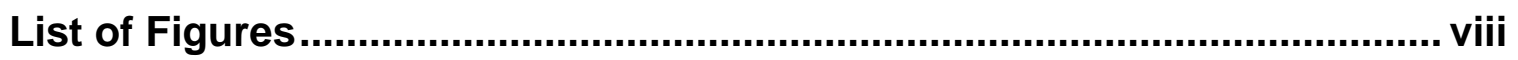

List of Commonly used Acronyms and Abbreviations ................................. $\mathrm{X}$

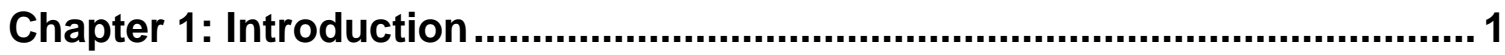

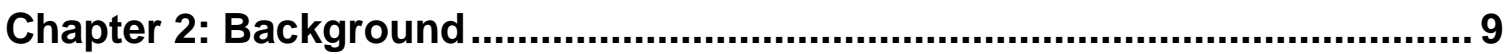

Description of Study Area ……..................................................................

Geologic Setting ......................................................................................10

Chapter 3: The Groundwater Model ........................................................15

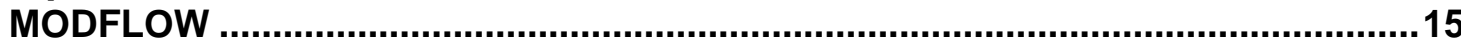

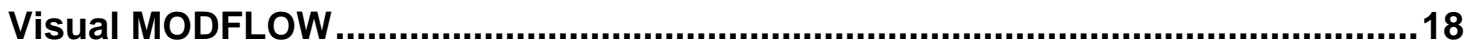

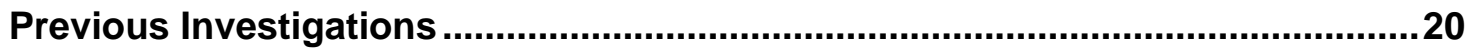

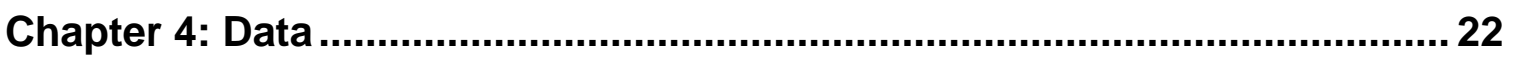

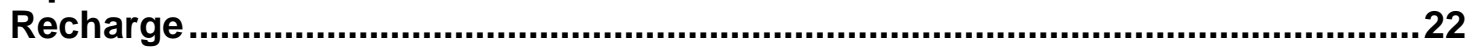

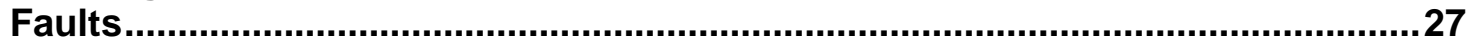

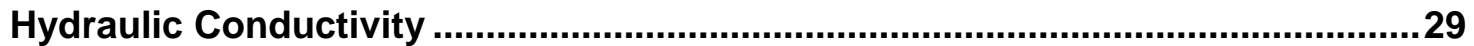

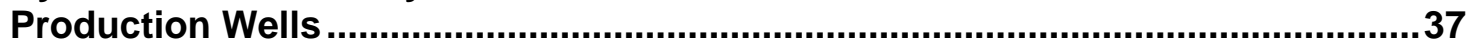

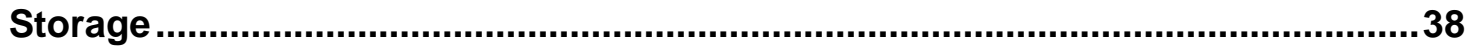

Chapter 5: Data Pre-Processing and Model Building ................................... 41

Spatial Discretization ....................................................................................... 41

Conversions from Latitude and Longitude to UTM and Model Coordinates .......47

Observation Wells .....................................................................................48

Concentration Observation Sites ...............................................................

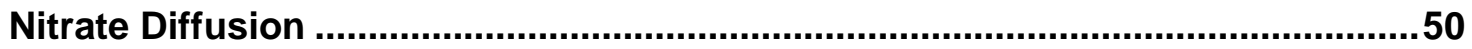

Chapter 6: Calibration of Visual MODFLOW Models .................................... 52

Groundwater Model Calibration ................................................................52

Data Validation .................................................................................................61

Chapter 7: Alternative Scenarios of Future Aquifer Management ...............66

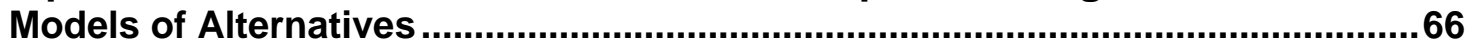

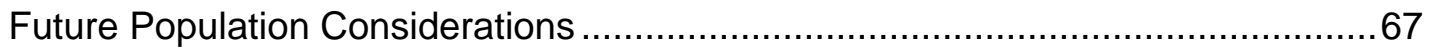

Future Groundwater Pumping Considerations ……………………………..... 70

Future Recharge and Recharge Concentration Considerations .............................77

Alternative Scenarios............................................................................................81

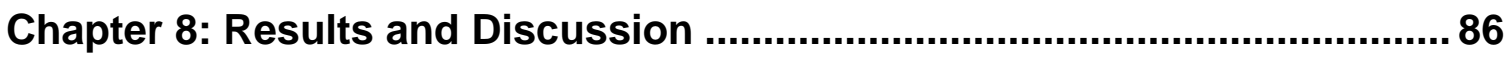

Chapter 9: Conclusions and Recommendations ....................................... 104

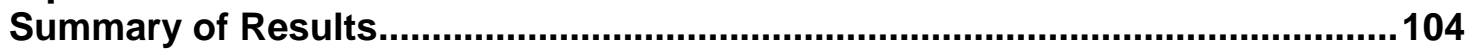

Model Limitations....................................................................................106

Suggestions for Future Work .............................................................................108

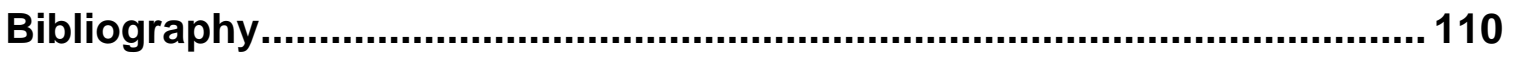

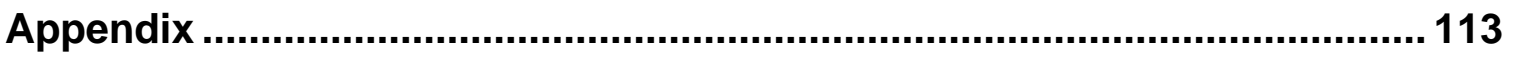




\section{List of Tables}

Table 1: Recent Concentrations of Nitrate (as Nitrate) in the BeaumontCherry Valley Water District1F0F0F ................................................ 7

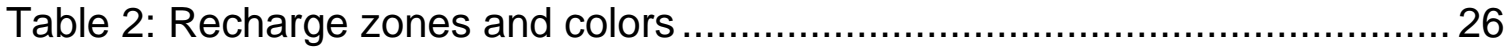

Table 3: Assumed grain sizes and hydraulic conductivities for soil types............ 31

Table 4: Original and Calibrated Hydraulic Conductivity factors .........................54

Table 5: Calibrated hydraulic conductivity at production wells, ft/day .................55

Table 6: Historical Population of Beaumont and Cherry Valley2F1F1F............. 68

Table 7: SCAG/WRCOG Population Estimates (Beaumont-Cherry Valley

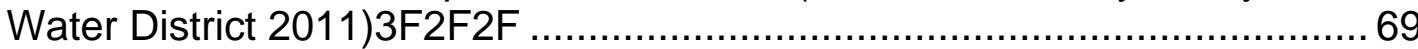

Table 8: 2010 UWMP Population and Household Projections (Beaumont-

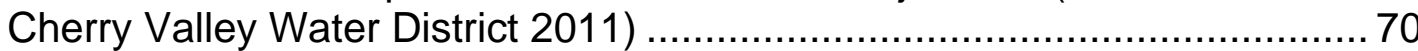

Table 9: Pumping rates for BCVWD production wells in projected models ........ 75

Table 10: Initial Nitrate Concentrations for Projected Scenarios........................ 77

Table 11: Recharge Rates Assigned to Potential Development in Cherry Valley, ft/day ................................................................................ 79

Table 12: Summary of Variables for Recharge and Well Pumping Rates .......... 81

Table 13: Nitrate concentrations for Projected Alternatives. 


\section{List of Figures}

Figure 1: Conventional onsite wastewater treatment system (U.S.

Environmental Protection Agency 2002) ………….............................. 3

Figure 2: The Nitrogen Cycle (Agency 2007) ........................................... 4

Figure 3: Beaumont, with Riverside County and California (Arkyan 2007) ........... 9

Figure 4: Row 63 of the groundwater model, 15x vertical exaggeration ............. 12

Figure 5: Column 176 of the groundwater model, 10x vertical exaggeration ...... 13

Figure 6: Assumed locations of homes on septic tank systems (Google

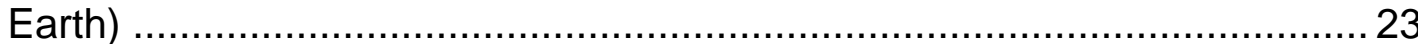

Figure 7: Assigned Recharge Zones for modeling before 2010 ..................... 25

Figure 8: Faults and general head boundaries .......................................... 28

Figure 9: Vertical hydraulic Conductivity in Layer 4 ........................................ 33

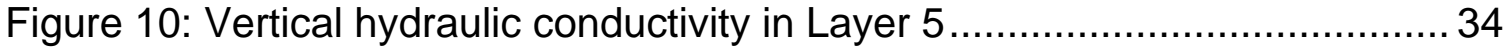

Figure 11: Horizontal hydraulic conductivity, layer 4..................................... 35

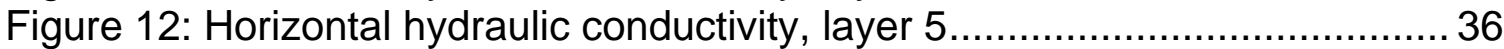

Figure 13: Specific Yield for the Beaumont Basin......................................... 40

Figure 14: TIFF image of DEM used for assigning Ground Surface

Elevation................................................................................... 42

Figure 15: Layer Elevations in the Beaumont Basin, view from East to

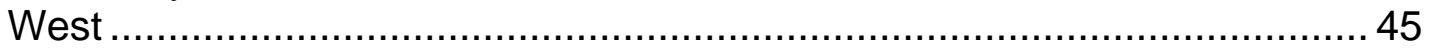

Figure 16: Layer Elevations in the Beaumont Basin, view from North to

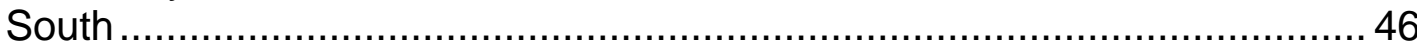

Figure 17: Calculated vs. Observed Heads for 379 Day model, at 0.07

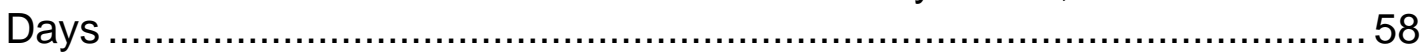

Figure 18: Calculated vs. Observed Heads for 379 Day model, at day 379 ....... 59

Figure 19: Residuals vs. time, 379 day model .............................................6

Figure 20: Calculated vs. Observed head, 1278 day model, Day $25 . \ldots \ldots \ldots \ldots \ldots . . . .62$

Figure 21: Calculated vs. Observed head, 1278 day model, day 360 ................63 63

Figure 22: Calculated vs. Observed head, 1278 day model, day 1278 ............. 64

Figure 23: Residuals vs. time, 1278 day model ..............................................65

Figure 24: Pumping Volumes over Time in the Beaumont Basin....................... 71

Figure 25: Total Average GPM vs. Population (1980 through 2010) ................. 72

Figure 26: Projected vs. historical pumping rates in the Beaumont Basin .......... 73

Figure 27: Future Recharge, with housing developments and golf courses ....... 80

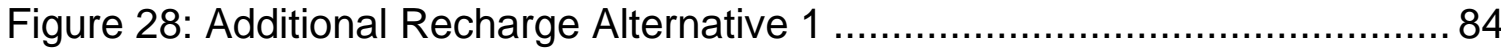

Figure 29: Additional Recharge Alternative 2 …..................................... 84

Figure 30: Nitrate (mg/L), General Forecast, Day 26/May 31, $2010 \ldots \ldots \ldots \ldots \ldots \ldots . . .88$

Figure 31: Nitrate (mg/L), General Forecast, Day 2035/Nov. 30, 2015 ............. 88

Figure 32: Nitrate (mg/L), General Forecast, Day 3952/Feb. 28, 2021 ............. 89

Figure 33: Nitrate (mg/L), General Forecast, Day 5719/Dec. 31, 2025 .............. 89

Figure 34: Nitrate (mg/L), General Forecast, Day 7545/Dec. 31, 2030 .............. 90

Figure 35: Nitrate (mg/L), General Forecast, Day 9371/Dec. 31, 2035 ............. 90

Figure 36: Nitrate (mg/L), Alternative 6, Day 2035/Nov. 30, 2015 .................... 92

Figure 37: Nitrate (mg/L), Alternative 6, Day 4166/Sep. 30, 2021 .................... 92

Figure 38: Nitrate (mg/L), Alternative 6, Day 5688/Nov. 30, $2025 \ldots \ldots \ldots \ldots \ldots \ldots \ldots . . . . .13$ 
Figure 39: Nitrate (mg/L), Alternative 6, Day 7514/Nov. 30, $2030 \ldots \ldots \ldots \ldots \ldots \ldots . . . .93$

Figure 40: Nitrate (mg/L), Alternative 6, Day 9065/Feb. 28, $2035 \ldots \ldots \ldots \ldots \ldots \ldots . . . .94$

Figure 41: Nitrate (mg/L), Recharge Alternative 1, Day 2035/Nov. 30, 2015..... 95

Figure 42: Nitrate (mg/L), Recharge Alternative 1, Day 3952/Feb. 28, 2021 ...... 95

Figure 43: Nitrate (mg/L), Recharge Alternative 1, Day 5719/Dec. 31, 2025..... 96

Figure 44: Nitrate (mg/L), Recharge Alternative 1, Day 7545/Dec. 31, 2030...... 96

Figure 45: Nitrate (mg/L), Recharge Alternative 1, Day 9371/Dec. 31, 2035..... 97

Figure 46: Nitrate (mg/L), Recharge Alternative 2, Day 2035/Nov. 30, 2015..... 97

Figure 47: Nitrate (mg/L), Recharge Alternative 2, Day 3952/Feb. 28, 2021 ...... 98

Figure 48: Nitrate (mg/L), Recharge Alternative 2, Day 5719/Dec. 31, 2025...... 98

Figure 49: Nitrate (mg/L), Recharge Alternative 2, Day 7545/Dec. 31, 2030...... 99

Figure 50: Nitrate (mg/L), Recharge Alternative 2, Day 9371/Dec. 31, 2035...... 99

Figure 51: Nitrate (mg/L), Septic tank loading, Day 26/May 31, 2010, Lay.

3

Figure 52: Nitrate (mg/L), Septic tank loading, Day 26/May 31, 2010, Lay.

4

Figure 53: Nitrate (mg/L), Septic tank loading, Day 26/May 31, 2010, Lay.

5 102

Figure 54: Nitrate (mg/L), Septic tank loading, Day 9371/Dec. 31, 2035, Lay. 3 102

Figure 55: Nitrate (mg/L), Septic tank loading, Day 9371/Dec. 31, 2035, Lay. 4 103

Figure 56: Nitrate (mg/L), Septic tank loading, Day 9371/Dec. 31, 2035, Lay. 5 103

Figure 57: Nitrate (mg/L), no changes to pumping rates, Dec. 31, 2035 107

Figure 58: Layer Elevations in the Beaumont Basin, view from South to North 116

Figure 59: Vertical hydraulic conductivity, layer 1 117

Figure 60: Vertical hydraulic conductivity, layer 2 118

Figure 61: Vertical hydraulic conductivity, layer 3 119

Figure 62: Horizontal hydraulic conductivity, layer 1 120

Figure 63: Horizontal hydraulic conductivity, layer 2 121

Figure 64: Horizontal hydraulic conductivity, layer 3 122 


\section{List of Commonly used Acronyms and Abbreviations}

BCVWD Beaumont-Cherry Valley Water District

DEM Digital Elevation Model

Lay. $\quad$ Layer

MCL Maximum Contaminant Level

NAD 83 North American Datum of 1983

NAVD 88 North American Vertical Datum of 1988

NGVD 29 National Geodetic Vertical Datum of 1929

prb Peninsular Ranges-type crystalline formations

QI Surficial deposits - Landslide

Qo $\quad$ Surficial deposits - Old

Qsl Lower region of Younger Sedimentary Deposits

Qsu Upper region of Younger Sedimentary Deposits

QTso Mt. Eden beds of Frick/San Timoteo beds of Frick

Qvo $\quad$ Surficial deposits - Very Old

Qy $\quad$ Surficial deposits - Young

SGPWA San Gorgonio Pass Water Agency

SWP California State Water Project

THM Trihalomethane

trb San Gabriel Mountains-type crystalline rocks

USGS United States Geological Survey

USGS SIR USGS Scientific Investigations Report 2006-5026 


\section{Chapter 1: Introduction}

Groundwater is a large component of fresh water available for human consumption. Groundwater is found in underground rock formations called aquifers, which contain water within small pore spaces between coarse- and finegrained soils. Within the United States, over $60 \%$ of the land area in the conterminous United States overlies aquifers, and every state has usable groundwater (U.S. Environmental Protection Agency 1992).

Many communities depend on groundwater as a primary source for drinking water. The United States Geological Survey (USGS) estimates that in 2005 , about $20 \%(82,600$ MGD) of all water withdrawals in the United States came from groundwater sources, and about $98 \%$ of domestic water use $(3,740$ MGD) was from groundwater sources (USGS 2011). Because use of groundwater is so ubiquitous, it is important to investigate potential sources of pollution to groundwater sources, so that current pollution can be mitigated to avoid future health problems and larger scale cleanup.

There are many potential sources of groundwater pollution. Leaky underground storage tanks, such as storage tanks used to hold gasoline at gas stations, can introduce gasoline and other hazardous chemicals to aquifers. Municipal landfills, where solid waste is disposed, can also contain hazardous chemicals that can leach into the local hydrogeological formations. Agricultural activities, such as heavy use of fertilizers and pesticides, introduce these chemicals to surface water which can eventually percolate into aquifers (U.S. Environmental Protection Agency 1992). 
Another major source of groundwater pollution is the use of septic tank systems to dispose of wastewater. Septic tank systems have traditionally been used in rural areas that may not have access to or the ability to develop a centralized wastewater removal and treatment infrastructure. Most onsite wastewater treatment systems have a septic tank and a drain field that allows the wastewater to infiltrate the soil, where it is purified (U.S. Environmental Protection Agency 2002).

A septic tank serves as a settling and skimming tank and as an unheated, unmixed anaerobic digester. Solids that are large enough within the wastewater settle to the bottom of the tank, while greases and light materials float to the surface of the wastewater, creating a scum layer. The partially treated, cleaner water between these two layers is allowed to flow through the tank to a soil absorption field. "The organic material retained in the bottom of the tank undergoes facultative and anaerobic decomposition and is converted to more stable compounds and gases such as carbon dioxide $\left(\mathrm{CO}_{2}\right)$, hydrogen sulfide $\left(\mathrm{H}_{2} \mathrm{~S}\right)$, and methane $\left(\mathrm{CH}_{4}\right)$. Because of this conversion, the volume of the material being deposited is being reduced continually, although there is always a net accumulation in the tank. Because the accumulation of scum and solids reduces the effective settling capacity of the tank, the contents of the tanks should be pumped periodically" (Tchobanoglous and Schroeder 1985).

The soil absorption system allows the treated wastewater to flow into the soil, where it can be purified further, as pictured in Figure 1. The treated effluent leaves the septic tank and enters a leach or drain field, which consists of gravel 
trenches and perforated pipes that distribute the treated effluent to these trenches. The septic tank effluent will infiltrate the soil on either the bottom or sides of the trenches (Tchobanoglous and Schroeder 1985).

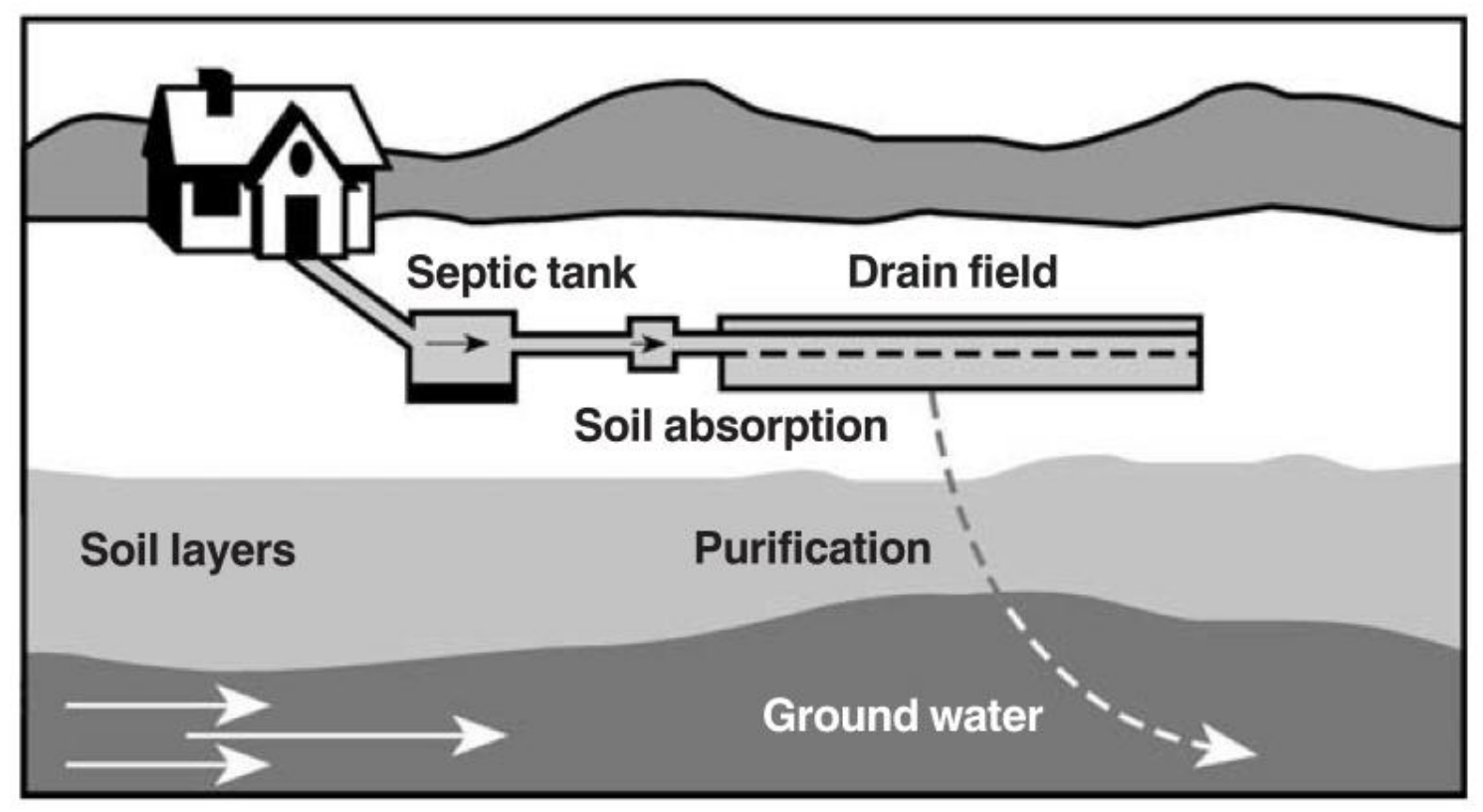

Source: NSFC, 2000.

Figure 1: Conventional onsite wastewater treatment system (U.S. Environmental Protection Agency 2002)

One of the major pollutants that can come from septic tank systems is nitrogen in the form of nitrate. Nitrogen is a naturally occurring element that interacts with the atmosphere, soil, and groundwater through the nitrogen cycle, pictured in Figure 2. 


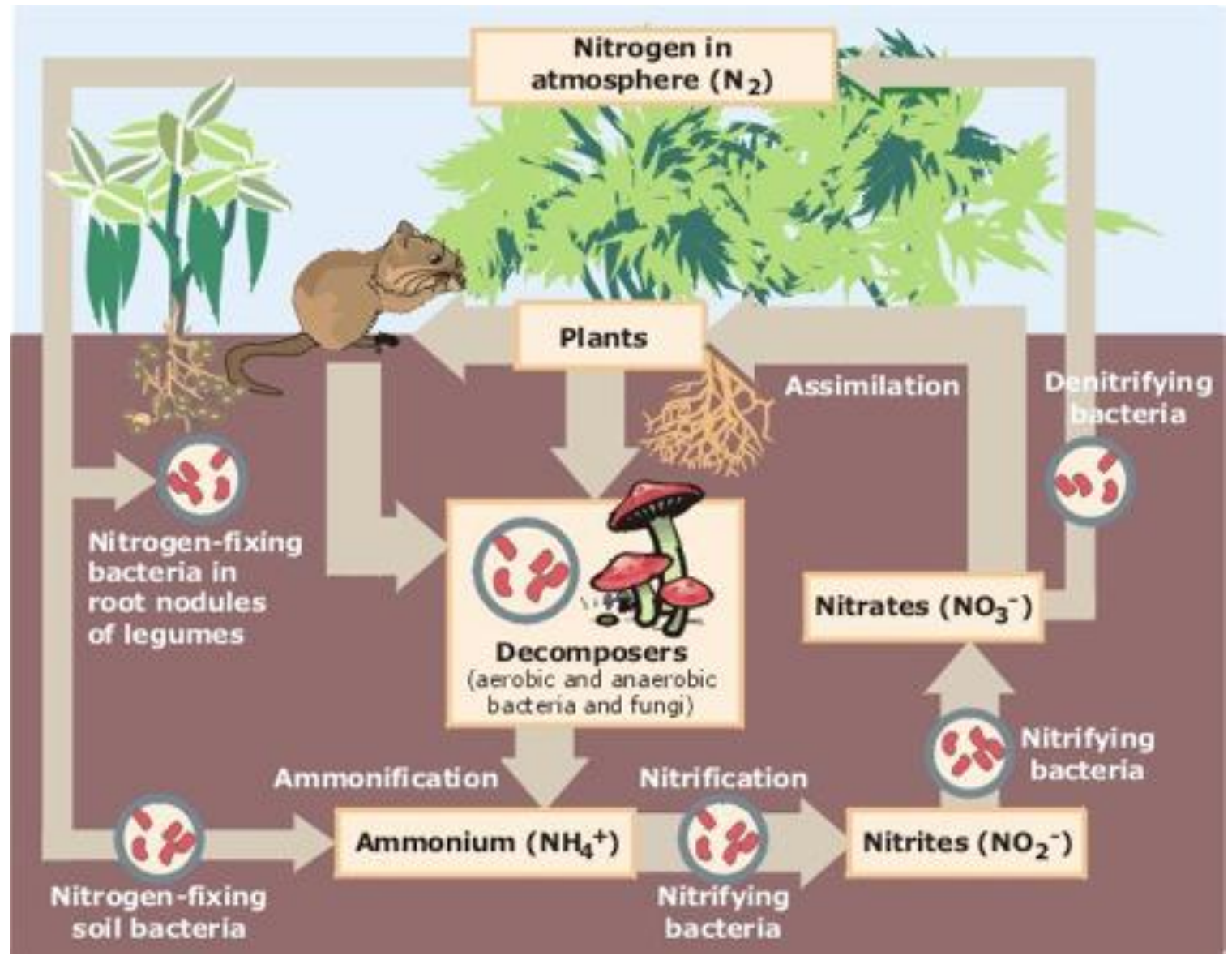

Figure 2: The Nitrogen Cycle (Agency 2007)

In the nitrogen cycle, atmospheric dinitrogen $\left(\mathrm{N}_{2}\right)$ is typically fixated into ammonia $\left(\mathrm{NH}_{3}\right)$ naturally through bacteria (Payne 1981), although fixation can also occur naturally from lighting strikes or artificially through industrial practices such as the Haber-Bosch Process to convert $\mathrm{N}_{2}$ into $\mathrm{NH}_{3}$ (Neider and Benbi 2008).

Once Nitrogen has been converted into $\mathrm{NH}_{3}$, it can then be converted into nitrite $\left(\mathrm{NO}_{2}^{-}\right)$and nitrate $\left(\mathrm{NO}_{3}{ }^{-}\right)$by nitrifying bacteria. Nitrosoccus and Nitrosomonas oxidize ammonia into nitrite, and species of Nitrobacter oxidize nitrite into nitrate (Payne 1981).

$$
\mathrm{NH}_{3} \rightarrow \mathrm{NO}_{2}^{-} \rightarrow \mathrm{NO}_{3}^{-}
$$


Later, depending on the species of bacteria available and the given environmental conditions, another process called denitrification can take place, which converts nitrate into dinitrogen over several steps, with many organisms in between. (Payne 1981) As seen in Figure 2, in addition to denitrifying bacteria, nitrate at a shallow enough depth to reach plant roots can also be absorbed by plants and assimilated into plant organisms.

$$
2 \mathrm{NO}_{3}^{-} \rightarrow 2 \mathrm{NO}_{2}^{-} \rightarrow 2 \mathrm{NO} \rightarrow \mathrm{N}_{2} \mathrm{O} \rightarrow \mathrm{N}_{2}
$$

While nitrate is a natural component of the nitrogen cycle, too much nitrate within an aquifer system can cause health problems for humans. According to the U.S. EPA Onsite Water Treatment Systems Manual,

"Excessive nitrate-nitrogen in drinking water can cause methemoglobinemia in infants and pregnancy complications for women. Livestock can also suffer health impacts from drinking water high in nitrogen"

(U.S. Environmental Protection Agency 2002).

Methemoglobinemia, or "blue baby syndrome," is a condition from excessive nitrogen ingestion where nitrates in the body prevent blood from delivering oxygen to the skin and organs, causing a blue tint to the skin. In severe cases, methemoglobinemia can cause coma or death (U.S.

Environmental Protection Agency 2011). To avoid excessive ingestion of nitrates, the U.S. EPA has set the maximum contamination level (MCL) for nitrate as nitrogen in drinking water at $45 \mathrm{mg} / \mathrm{L}$. According to the U.S. EPA Onsite Wastewater Treatment Systems Manual, the typical mass loading of total nitrogen in residential wastewater ranges from 6-17 grams/person/day, and the typical concentration of total nitrogen in residential wastewater ranges from 26-75 
$\mathrm{mg} / \mathrm{L}$. For comparison, there is a mass loading less than $1 \mathrm{gram} /$ person/day and a concentration of less than $1 \mathrm{mg} / \mathrm{L}$ in typical residential wastewater for nitrites and nitrates (U.S. Environmental Protection Agency 2002).

This thesis examines the Beaumont Basin, an aquifer in southern California underneath the city of Beaumont and unincorporated area of Cherry Valley. While homes in Beaumont are connected to a sewer system that directs wastewater to a treatment facility, many homes in Cherry Valley use septic tank systems to dispose of wastewater. While there have been regulations enacted within Cherry Valley that prevent future septic tank systems from being installed unless they meet specific treatment criteria (University of California, Riverside 2012), most homes in Cherry Valley still use septic tank systems. The density of homes in Cherry Valley that currently use septic tank systems for wastewater disposal raises some questions about their sustainability and potential for groundwater contamination.

Within the Beaumont-Cherry Valley Water District boundaries, nitrate concentrations are monitored at least once a year in many production and private wells throughout the Beaumont Basin. The concentrations of nitrate, as well as of many other contaminants, are released on an annual basis in Consumer Confidence Reports. The average, highest, and lowest nitrate concentration from recent consumer confidence reports are shown in Table 1. As previously mentioned, the MCL for nitrate is $45 \mathrm{mg} / \mathrm{L}$. All of the wells sampled in recent years have met this MCL, though some wells in the Cherry Valley region of the Beaumont Basin have generated samples with nitrate concentrations near the 45 
$\mathrm{mg} / \mathrm{L}$ MCL.

Table 1: Recent Concentrations of Nitrate (as Nitrate) in the Beaumont-Cherry Valley Water District.. ${ }^{1}$

\begin{tabular}{|c|c|c|c|}
\hline Year & $\begin{array}{c}\text { Average } \\
\text { Concentration } \\
(\mathrm{mg} / \mathrm{L})\end{array}$ & $\begin{array}{c}\text { Highest Sampled } \\
\text { Concentration } \\
(\mathrm{mg} / \mathrm{L})\end{array}$ & $\begin{array}{c}\text { Lowest Sampled } \\
\text { Concentration } \\
(\mathrm{mg} / \mathrm{L})\end{array}$ \\
\hline 2006 & 8.2 & 40 & 3.1 \\
\hline 2007 & 6.86 & 16 & 2.5 \\
\hline 2008 & 6.8 & 16 & 3.1 \\
\hline 2009 & 6.3 & 18 & 2.7 \\
\hline 2010 & 9.3 & 38 & 3.1 \\
\hline
\end{tabular}

To evaluate current and future conditions of water quality within an aquifer, a computer modeling approach is often the best way to analyze an aquifer. Due to the size of many aquifers, there is some difficulty in measuring depth to groundwater and taking groundwater samples for quality analysis. Depending on the size of the aquifer and the distribution of production wells, it may take days to collect and analyze this data, and field and lab experiments can become costly. While field and lab data does help define current scenarios for groundwater quality, it is impossible to determine future water quality from current water samples. Using computer modeling, it is possible to develop an idea of future groundwater movement and quality, based on current data and reasonable assumptions about future aquifer management and hydrologic balance.

This project investigates methods of modeling contaminant flow in groundwater through the use of modeling software, such as MODFLOW-2005 (Harbaugh 2005) and Visual MODFLOW (Schlumberger Water Services 2010),

\footnotetext{
${ }^{1}$ (Beaumont-Cherry Valley Water District 2011) (Beaumont-Cherry Valley Water District 2010) (Beaumont-Cherry Valley Water District 2009) (Beaumont-Cherry Valley Water District 2008) (Beaumont-Cherry Valley Water District 2007)
} 
and traditional groundwater theory. The applications of the methodologies presented in this thesis are focused on a groundwater model of the Beaumont Basin.

A groundwater model has been constructed to better understand the movement of groundwater flows within the Beaumont Basin. This model accounts for flows in the Beaumont Basin caused by major pumping wells, natural and artificial recharge, and recharge from septic tank systems in Cherry Valley that contribute to nitrate contamination of the Beaumont Basin. The model principally uses data from the United States Geological Survey (USGS) as well as the Beaumont-Cherry Valley Water District (BCVWD) and the San Gorgonio Pass Water Agency (SGPWA). The model accounts for past and current groundwater production, as well as future production needs based on projected population changes and previous pumping rates. The study incorporates possible future alternatives that suggest changes and additions to existing groundwater production infrastructure to account for nitrate movement and concentration within the Beaumont Basin. 


\section{Chapter 2: Background}

\section{Description of Study Area}

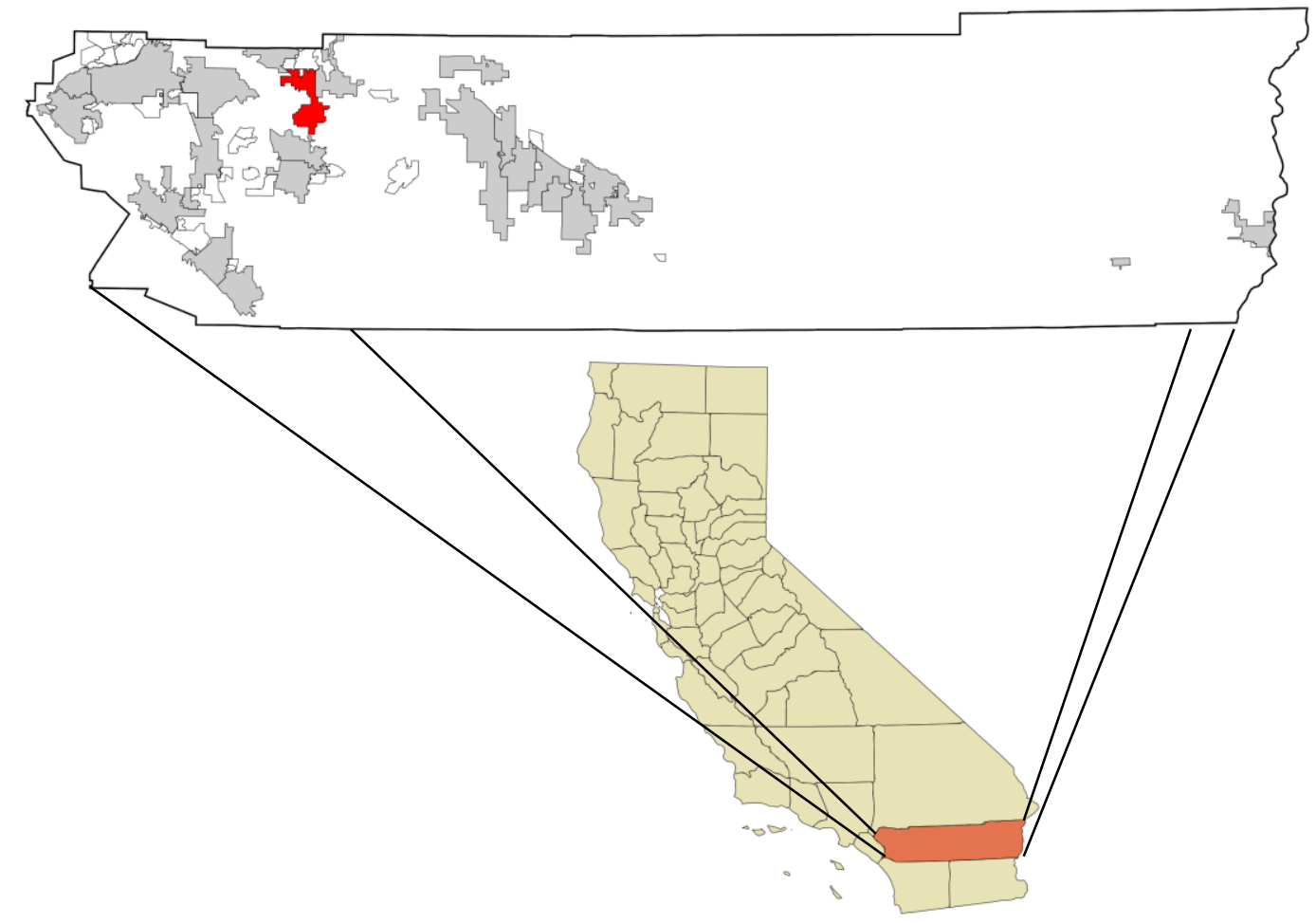

Figure 3: Beaumont, with Riverside County and California (Arkyan 2007)

The groundwater hydraulics and contaminant transport model developed in this study to analyze nitrate contamination coming from septic tank systems is based in Beaumont and Cherry Valley, California, two relatively small communities in southern California approximately 80 miles east of Los Angeles in Riverside County. Beaumont, CA, $\left(33^{\circ} 55^{\prime} 46.06^{\prime \prime} \mathrm{N}, 116^{\circ} 58^{\prime} 38.09 " \mathrm{~W}\right)$ has a population of approximately 36,000 residents as of 2010 , and is primarily a commuter community for Riverside, San Bernardino, and Los Angeles counties. The city limits of Beaumont are highlighted in red in Figure 3. Cherry Valley, CA, $\left(33^{\circ} 58^{\prime} 21.05^{\prime \prime} \mathrm{N}, 116^{\circ} 58^{\prime} 38.09^{\prime \prime} \mathrm{W}\right)$ is an unincorporated area to the north of Beaumont whose 6,300 residents include a mix of commuters and retirees. 
The majority of domestic water for the communities of Beaumont and Cherry Valley is provided by the Beaumont-Cherry Valley Water District (BCVWD), which draws water from the local Beaumont Basin aquifer to serve all water needs. There are a few entities within the study area that do not use water provided by BCVWD and also draw water from wells in the Beaumont Basin, but these users tend to have relatively small well production (Davis, Email conversation 2011). The BCVWD maintains several production wells in Beaumont and Cherry Valley, as well as a distribution network that includes pipelines, pumps, and reservoirs. The BCVWD also maintains the Noble Creek Recharge Project which began recharging California State Water Project (SWP) water to the Beaumont Basin in 2006 (Beaumont-Cherry Valley Water District 2011).

In Cherry Valley, most homes are not connected to a sewer system, and instead rely on septic tank systems to dispose of domestic wastewater. There are over 200 septic tanks per square mile in areas of Cherry Valley. A density of 40 septic tanks per square mile is considered a contamination situation (Wiffley 2009).

\section{Geologic Setting}

The geology of the Beaumont Basin can be generalized into crystalline basement rocks and late Cenozoic sedimentary deposits. The Crystalline basement rocks are hard, low-permeability formations that form the foundation of the Beaumont Basin. Peninsular Ranges-type crystalline formations (prb) crop out in the San Jacinto Mountains to the south of Beaumont, and are assumed to form the basement of much of the Beaumont Basin. The Peninsular Ranges- 
type formations are made up of Mesozoic (Cretaceous) plutonic rocks of various granitoid compositions and older metasedimentary rocks that consist of marble and quartzofeldspathic biotite gneiss and schist (Rewis, et al. 2006). On the north side of the Beaumont Basin, to the north of the Banning fault, are San Gabriel Mountains-type crystalline rocks (trb). These formations are mainly plutonic granitoid rocks that have a composition ranging from granodioritic to tonalitic. San Gabriel Mountains-type rock is also generally very weathered and fractured, readily crumbling in some areas (Rewis, et al. 2006).

Above the crystalline basement formations lie the late Cenozoic Sedimentary Deposits. According to the United States Geological Survey Scientific Investigation Report 2006-5026 (USGS SIR), the sedimentary deposits can be placed into three major groups: older sedimentary deposits, younger sedimentary deposits, and surficial deposits (Rewis, et al. 2006).

The older sedimentary deposits include two formations: the Mt. Eden beds of Frick and some older portions of the San Timoteo beds of Frick (QTso). While these deposits are exposed to the south and southwest of the Beaumont Basin in the San Timoteo Badlands, they are typically buried deeply within the Beaumont Basin, in some areas as deep as 1500 feet. Many of the formations in the older sedimentary deposits include: "well-consolidated to cemented, light-gray to very pale-brown, well-sorted fine- to coarse-grained sand and sandstone; sheet-like layers of well-consolidated to indurated, light-gray pebble-cobble gravel and conglomerate as much as $30 \mathrm{ft}$ thick containing clasts of granitic, gneissic, mylonitic, and hypabyssal rock of San Gabriel Mountains-type; well-consolidated 
and compacted, greenish-gray mudstone and silty very fine-grained sand and sandstone; and reddish-colored siltstone and fine-grained sand and sandstone that locally are clay-rich; some intervals may be paleosols" (Rewis, et al. 2006).

The younger sedimentary deposits lie above the older sedimentary deposits, and is generally divided into lower (Qsl) and upper (Qsu) regions of younger sedimentary deposits. The lower layer of younger sedimentary deposits consists of pale brown to yellowish-brown sand and sandstone, with some gravel and clasts of local San Gabriel Mountains-type. The lower younger sedimentary layer tends to be more consolidated than the upper younger sedimentary layer, giving it a lower hydraulic conductivity (Rewis, et al. 2006). The various ages of soil layers can be seen below in Figure 4 and Figure 5.

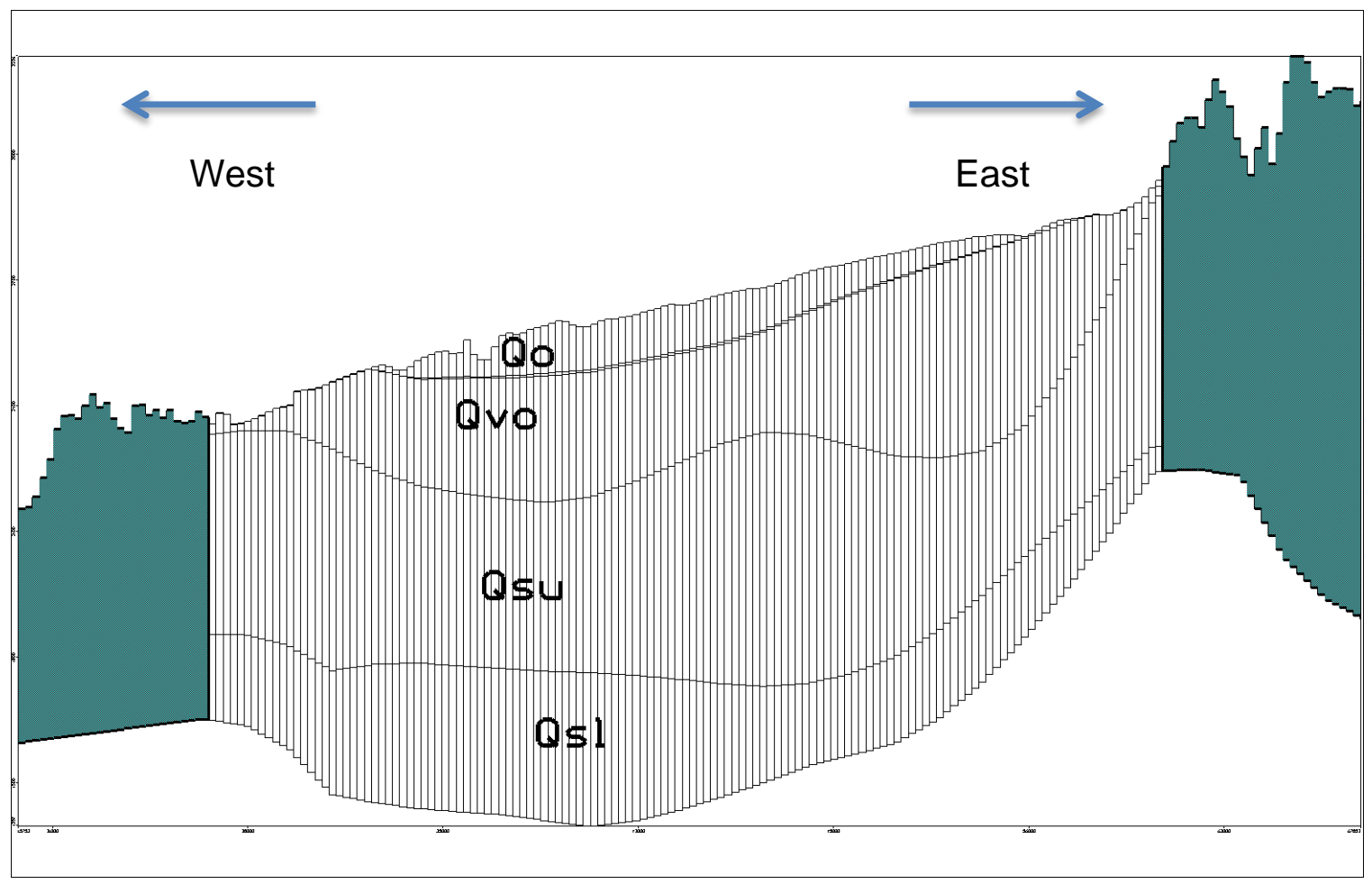

Figure 4: Row 63 of the groundwater model, 15x vertical exaggeration 


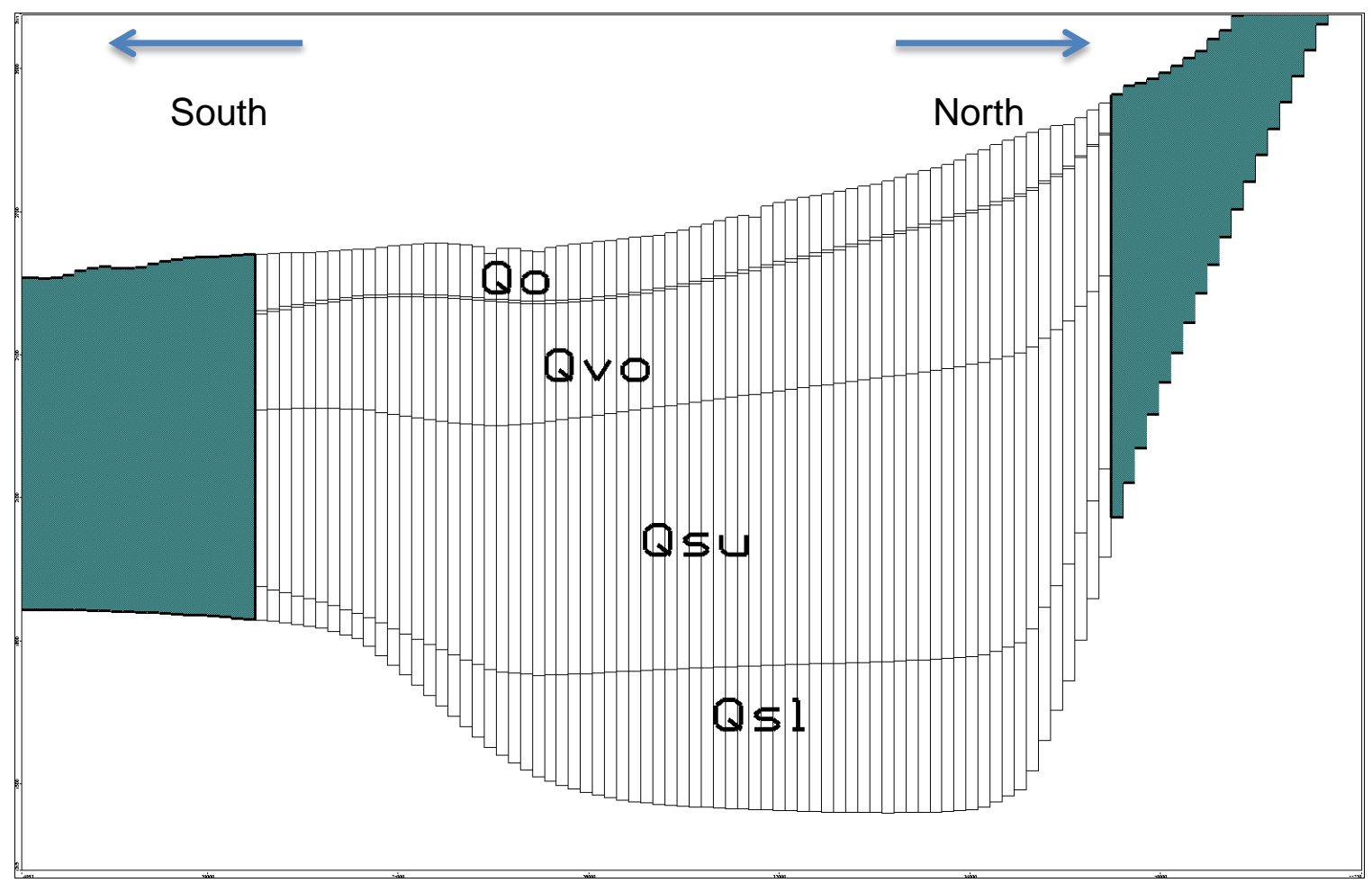

Figure 5: Column 176 of the groundwater model, $10 x$ vertical exaggeration

The upper layer of the younger sedimentary deposits consists of grayishto yellowish-brown sand and gravel layers. This layer is cut by local caliche-lined faults, and the upper part of the deposit has irregular seams and zones of caliche or calcrete. In borehole electrical logs, the upper younger sedimentary deposit has a higher resistivity compared to the lower younger sedimentary deposit, indicative of fewer fine-grained materials such as clay and silt in the upper deposit. This difference in resistivity is what helps to distinguish the boundary between the upper and lower younger sedimentary deposits (Rewis, et al. 2006).

It is thought that the younger sedimentary deposits began to form in the Beaumont region about 1.5 million years ago, when the beds of the older sedimentary deposits began to be folded in an anticlinal uplift, with an axis parallel to the San Jacinto Fault Zone. This ended up forming the CalimesaCherry Valley basin. This basin then served as a depositional trough for alluvial 
deposits through present-day Beaumont and Cherry Valley, likely from streams that flowed from west to east through the Beaumont Basin (Rewis, et al. 2006).

The surficial deposits (Qvo, Qo, Qy, and Ql) within the Beaumont Basin consist of various kinds of deposits formed within the last half million years. These deposits include alluvial sand and gravel, loose hillside rubble, and landslide and other slope-movement materials. In general, these deposits are unconsolidated, but the level of consolidation tends to increase as depth and age of the deposits increases. The surficial deposits have relatively high resistivity in borehole electrical logs, indicative of fewer fine grain materials and unsaturated conditions. Most of the surficial layers are interlayered sand and gravel with intermittent layers of clay and silt (Rewis, et al. 2006).

Within the Cherry Valley region of the model, there is a perched aquifer setting to the north of the Cherry Valley fault. This perched aquifer is due to a layer of low permeability silts and clays that are deposited between the old and very old surficial deposits (Qo and Qvo) (Rewis, et al. 2006). This perched aquifer results in some observations wells showing dramatically different hydraulic head values over a relatively small spatial distribution (USGS 2011). 


\section{Chapter 3: The Groundwater Model MODFLOW}

The backbone of the computations for ground-water modeling can be done using a program called MODFLOW, an acronym for Modular ThreeDimensional Finite-Difference Ground-Water Flow Model. MODFLOW was first developed by USGS in 1981, and the first released version of the software, MODFLOW-88, was released in 1988. Since then, three other versions of the program have been released: MODFLOW-96, MODFLOW-2000, and MODFLOW-2005 (Harbaugh 2005).

MODFLOW is a "modular" program because it is divided into packages, which manage data and computations for various aspects of the groundwater simulation. A Recharge Package would handle simulation aspects of groundwater recharge, a River Package would handle simulation based on headdependent recharge, and a Well Package would handle simulation based on well hydraulics and volumetric outflow or inflow from wells. Since the program is designed so that each package handles a different part of the groundwater flow simulation, a user need only use packages relevant to a specific project, and packages are computed in an order to properly simulate groundwater flow (Harbaugh 2005).

The three-dimensional movement of ground water of constant density through porous earth material may be described by the partial-differential equation (Harbaugh 2005)

$$
\frac{\partial}{\partial x}\left(K_{x x} \frac{\partial h}{\partial x}\right)+\frac{\partial}{\partial y}\left(K_{y y} \frac{\partial h}{\partial y}\right)+\frac{\partial}{\partial z}\left(K_{z z} \frac{\partial h}{\partial z}\right)+W=S_{s} \frac{\partial h}{\partial t}
$$


where

$$
\begin{array}{ll}
K_{x x}, K_{y y}, \text { and } K_{z z} & \text { are values of hydraulic conductivity along the } \mathrm{x}, \mathrm{y} \text {, and } \mathrm{z} \\
& \text { coordinate axes, which are assumed to be parallel to the } \\
& \text { major axes of hydraulic conductivity }(\mathrm{L} / \mathrm{T}) ; \\
h & \text { is the potentiometric head }(\mathrm{L}) ; \\
W & \text { is a volumetric flux per unit volume representing sources } \\
& \text { and/or sinks of water, with } \mathrm{W}<0.0 \text { for flow out of the ground- } \\
& \text { water system, and } \mathrm{W}>0.0 \text { for flow into the system }\left(\mathrm{T}^{-1}\right) ; \\
S_{S} & \text { is the specific storage of the porous material }\left(\mathrm{L}^{-1}\right) ; \text { and } \\
t & \text { is time }(\mathrm{T})
\end{array}
$$

This equation describes ground-water flow under nonequilibrium conditions in a heterogeneous and anisotropic medium, if the main axes of hydraulic conductivity are aligned with the coordinate directions. The equation, with stated boundary and initial head conditions, creates a mathematical representation of a ground-water flow system. An analytical solution of the equation is one where the derivatives of hydraulic head, with respect to spatial coordinates and time, are continuous and meet the specified boundary conditions. By representing the aquifer as an array of head values that change with time, it is possible to show the volume and storage of groundwater, as well as direction and rates of flow (Harbaugh 2005).

However, a strictly analytical solution of the three-dimensional groundwater movement equation is usually only possible for a very simple system. For more complex system, a numerical method can be used to 
approximate a solution for the system. One approach is the finite-difference method, where the system is replaced by a finite set of points in space and time, and partial derivatives are replaced by terms calculated from the head differences at these points in space and time. This leads to a series of linear equations that can be used to describe the system; the solution of this set of linear equations can determine the head at specific points and times within the system. Because this method uses small differences to approximate the changes in the system, it provides an approximate solution to the set of linear equations (Harbaugh 2005).

To use the finite-difference method as a numerical solution to the groundwater flow equation, continuity within the system must be preserved: the sum of flows into and out of the system must equal the rate of change of storage. Given the assumption that the density of the groundwater is constant, we need only consider the volumetric flux within the system, rather than the specifics of mass transport. Thus, the balance of flow for a cell within the system can be described by

$$
\sum Q_{i}=S S \frac{\Delta h}{\Delta t} \Delta V
$$

where

$Q_{i} \quad$ is a flow rate into the cell $\left(\mathrm{L}^{3} \mathrm{~T}^{-1}\right)$

SS has been introduced as the notation for specific storage in the finitedifference formulation; its definition is equivalent to that of $S_{s}$ in the threedimensional groundwater movement equation - that is, SS is the volume of water that can be injected per unit volume of aquifer material per unit 
change in head $\left(\mathrm{L}^{-1}\right)$;

$\Delta V \quad$ is the volume of the cell $\left(L^{3}\right) ;$ and

$\Delta h \quad$ is the change in head over a time interval of length $\Delta t$ (Harbaugh 2005)

Within MODFLOW and in this report, there are conventions for the spatial discretization of a model system space. Systems are composed of rows, columns, and layers. Rows are given an index "i", columns are given an index "j", and layers are given an index "k". Typically, layers within a model correspond to major geologic strata within the actual study area.

$$
q_{i, j-\frac{1}{2}, k}=K R_{i, j-\frac{1}{2}, k} \Delta c_{i} \Delta v_{k} \frac{\left(h_{i, j-1, k}-h_{i, j, k}\right)}{\Delta r_{j-\frac{1}{2}}}
$$

where

$h_{i, j, k} \quad$ is the head at node $\mathrm{i}, \mathrm{j}, \mathrm{k}$ and $h_{i, j-1, k}$ is the head at node $\mathrm{i}, \mathrm{j}-1, \mathrm{k}$;

$q_{i, j-1 / 2, k} \quad$ is the volumetric flow rate through the face between cells $\mathrm{i}, \mathrm{j}, \mathrm{k}$ and $\mathrm{i}, \mathrm{j}-1, \mathrm{k}\left(\mathrm{L}^{3} \mathrm{~T}^{-1}\right)$;

$K R_{i, j-1 / 2, k}$ is the hydraulic conductivity along the row between nodes $\mathrm{i}, \mathrm{j}, \mathrm{k}$ and $\mathrm{i}, \mathrm{j}-1, \mathrm{k}\left(\mathrm{LT}^{-1}\right)$;

$\Delta c_{i} \Delta v_{k} \quad$ is the area of the cell faces normal to the row direction; and $\Delta r_{j-1 / 2} \quad$ is the distance between nodes nodes $\mathrm{i}, \mathrm{j}, \mathrm{k}$ and $\mathrm{i}, \mathrm{j}-1, \mathrm{k}(\mathrm{L})$

\section{Visual MODFLOW}

While MODFLOW is a strong program for developing groundwater models, it is not very user friendly and formatting input files correctly and interpreting output files can be time consuming and difficult. To make the 
groundwater modeling process more streamlined and easier to understand, a modeler can use software such as Visual MODFLOW that provide a user friendly, graphic interface for MODFLOW. Using Visual MODFLOW, it is possible to import text files, Microsoft Excel spreadsheets, and other common file types to bring data for various study area properties into the model. Once saved in a Visual MODFLOW project file, the Visual MODFLOW software can then generate the appropriate input data files for MODFLOW and run the MODFLOW computation engine to solve the groundwater flow problem (Schlumberger Water Services 2010).

In addition to running various releases of the MODFLOW computation engine, Visual MODFLOW Pro can also create input files for, execute, and read the output data of programs such as MODPATH, MT3DMS, and PEST.

MT3DMS is a program that can be used to model contaminant transport for multiple species within an aquifer. This software allows the user to specify transport properties for various species, such as dispersion, and allows the user to specify a rate of decay or reactions for contaminant species, if such reactions exist (Schlumberger Water Services 2010).

PEST is parameter estimation software that can be used to adjust the values of parameters within a model. Within Visual MODFLOW Pro, PEST can be used to calibrate values of hydraulic conductivity, storage, and recharge (Schlumberger Water Services 2010). See the Groundwater Model Calibration section on page 52 for more detailed information about PEST and the calibration process used for this study. All three computation engines, Visual MODFLOW, 
MT3DMS, and PEST, were used for this study.

\section{Previous Investigations}

There are a handful of previous groundwater studies that have been done for the Beaumont Basin. In 2006, the United States Geological Survey published Scientific Investigation Report 2006-5026 (USGS SIR), which investigates the geology, groundwater hydrology, and geochemistry of the Beaumont Basin and the neighboring Banning Basin, and conducts surface water and groundwater simulations using the INFILv3 and MODFLOW-96 software, respectively (Rewis, et al. 2006). In 2004, the Water Resources Division of the USGS in Sacramento, California created a groundwater model to evaluate the long-term infiltration and perched aquifer areas of the Beaumont Basin (Flint and Ellett 2004).

The USGS SIR has a very comprehensive approach to studying the hydrology and hydrogeology of the Beaumont Basin. The USGS SIR includes reports for the geology of the Beaumont Basin, surface water and rainfall that contribute recharge and surface flows into the Beaumont Basin, and a transient groundwater model of the Beaumont Basin which accounts for groundwater flow data from 1926 to 2003 (Rewis, et al. 2006). In the groundwater model, the conductivity throughout the study area is assumed to be homogeneous, and calibration of the model only changes one set of horizontal and vertical conductivities for the entirety of the model space. While this model does provide a good overall image of what groundwater hydraulics are like in the Beaumont Basin, the lack of different conductivities for all of the geologic layers and areas of the basin leave a desire for more detail in the analysis.

In the Flint and Ellet study of perched regions of the Beaumont Basin, the 
study offers much more detail for the different conductivities of the different layers of soil in the Cherry Valley region of the Beaumont Basin. This study assigns different values for the hydraulic conductivity at various depth intervals, and includes a thin, low-permeability layer of fine silt or clay that represents the perching layer of the Beaumont Basin within the Cherry Valley region. While this study does provide a greater detail of the changes in the conductive properties of the soil in the Cherry Valley region, the Flint and Ellet study does not account for soil properties outside of the Cherry Valley region.

This study seeks to combine many of the aspects of these two studies, specifically, the comprehensive nature of the USGS SIR with regards to the different factors influencing the hydraulic scenario within the Beaumont Basin and the increased level of detail provided in the Flint and Ellet study. Using sources for data and data preprocessing described in Chapters 4 and 5 , respectively, this study seeks to provide a more detailed, more comprehensive model of the Beaumont Basin. From there, this study develops a variety of hydraulic scenarios to evaluate different actions to help mitigate nitrate pollution in the Beaumont Basin from septic tank systems. 


\section{Chapter 4: Data}

\section{Recharge}

Recharge is contributed to the model area in several different ways. There are intermittent stream flows from seasonal storms that can contribute a significant volume of recharge in the Beaumont Basin. There are golf courses in the San Gorgonio Pass that irrigate heavily, which can percolate through the golf courses and into the Beaumont Basin. The majority of homes in the Cherry Valley area use septic tanks to dispose of wastewater, thus adding daily domestic water use as a recharging factor.

To simulate recharge from septic tank systems, it was necessary to develop a spatial distribution of the septic systems to show a more accurate distribution of recharge and potential nitrate contamination in the Cherry Valley region of the Beaumont Basin. The majority of homes in Cherry Valley are not connected to the Beaumont sewer system; these homes were noted with placemarks in Google Earth. Each placemark assigns a latitude and longitude to the homes in Cherry Valley. These placemarks were then gathered into a single file folder in Google Earth and exported as a single .kml file. The metadata from the. $\mathrm{kml}$ file can be interpreted by Microsoft Excel to create a spreadsheet table that contains each of the data fields from the. $\mathrm{kml}$ file, including the latitudes and longitudes of each placemark. Latitudes and longitudes in the Excel spreadsheet are separated by commas within single cells, so the latitudes and longitudes were copied into a .txt file, and then re-imported into Excel as a comma delimited text file to assign latitudes and longitudes to their own columns within the Excel 
spreadsheet. Figure 6 shows a Google Earth view of the homes selected as homes likely to have septic tank systems

Once the latitudes and longitudes data were compiled for each of the homes in Cherry Valley not on septic system, they were converted to UTM Zone 11 coordinates, model $x$ - and $y$-coordinates, and row and column coordinates. (See Conversions from Latitude and Longitude to UTM and Model Coordinates, page 47) The "countifs" function in Microsoft Excel was used to create a spreadsheet that contained an array of cell values with the total count of each placemark that contained matching row and column coordinates. For example, if, out of all the placemarks, there were 7 that were assigned to Row 45 , Column 156, then "7" could appear as the cell entry in row 45, column 156 in the spreadsheet array.

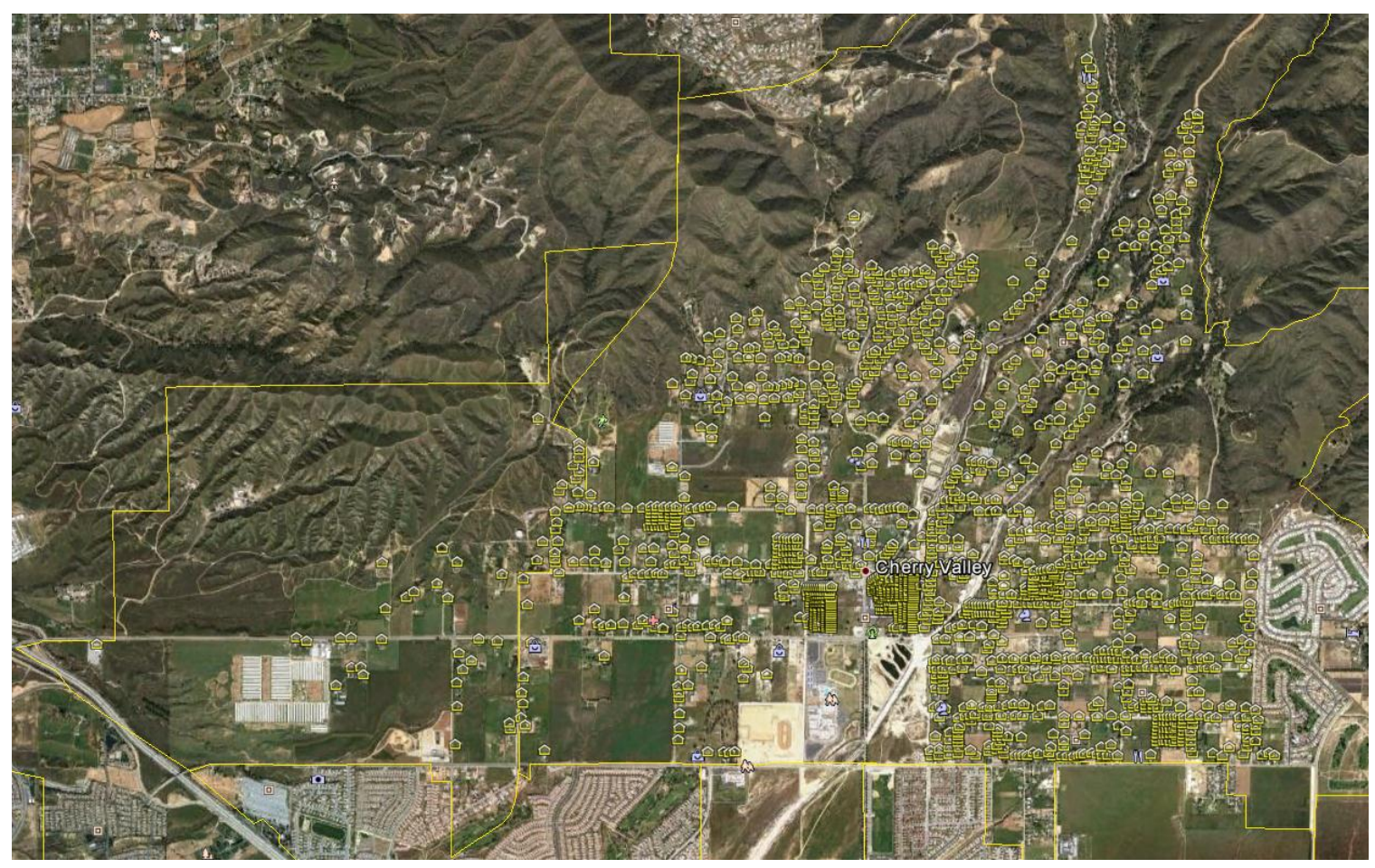

Figure 6: Assumed locations of homes on septic tank systems (Google Earth) 
Using this scheme, an array was developed that indicates the approximate number of homes per model cell. The distribution of recharge zones, including recharge related to the Noble Creek artificial recharge ponds, is shown in Figure 7. Using an average wastewater effluent quantity of $70 \mathrm{gal} / \mathrm{d} /$ person, as stated in the USGS SIR (Rewis, et al. 2006), recharge values were assigned to each cell based on the average household size in Cherry Valley of 2.4 residents per household and the estimated percentage of family homes at $71.5 \%$ (Onboard Informatics 2011) These data were used to provide an estimated average value of daily wastewater recharge due to septic tank infiltration. As mentioned in Chapter 1, typical nitrate effluent ranges from 25 to $75 \mathrm{mg} / \mathrm{L}$. For models in this study, recharge concentration for all current Cherry Valley homes is assumed to be $50 \mathrm{mg} / \mathrm{L}$ nitrate. 


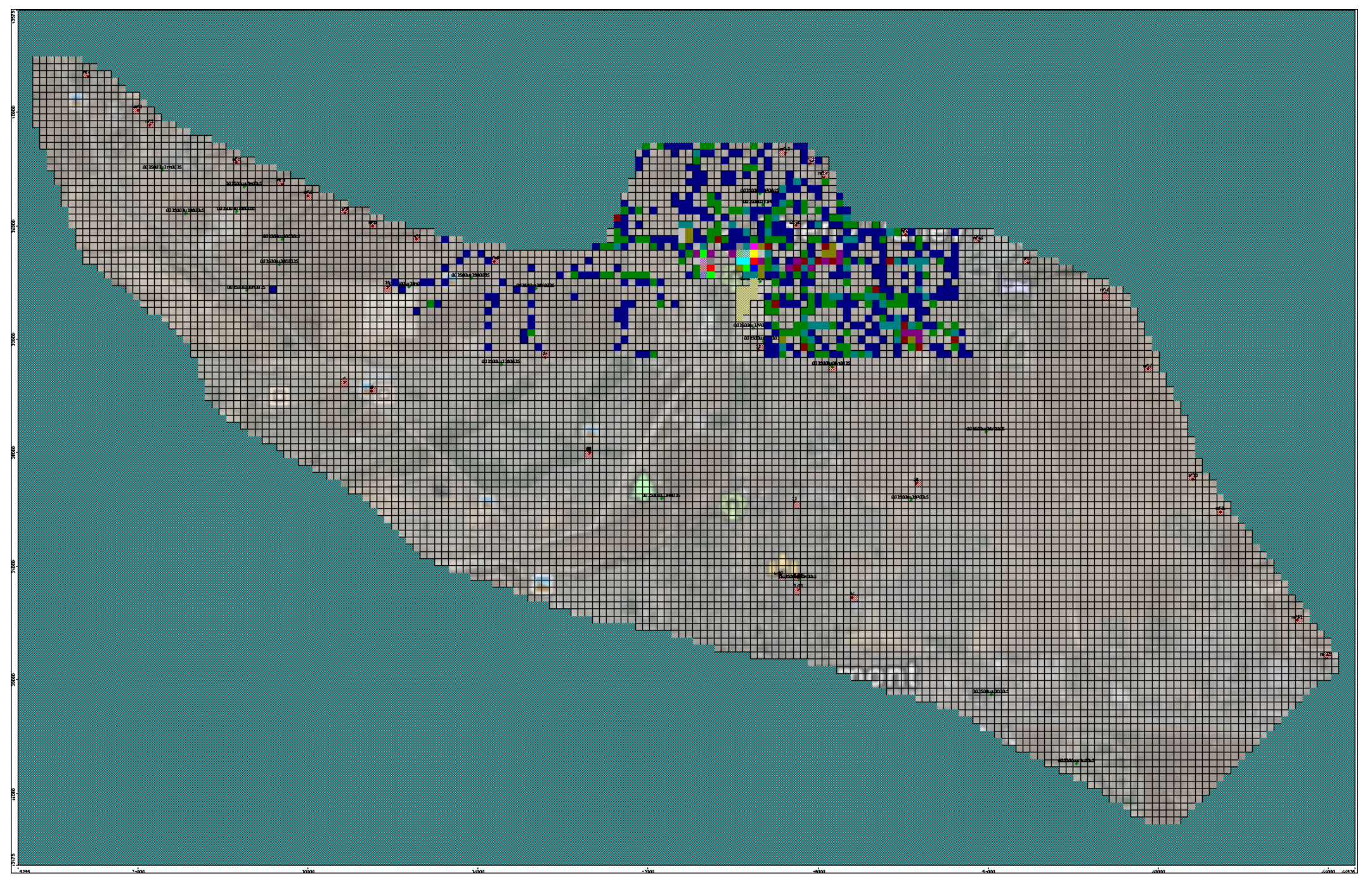

Figure 7: Assigned Recharge Zones for modeling before 2010 
Table 2: Recharge zones and colors

\begin{tabular}{|c|c|c|c|}
\hline \# of homes per cell & Color & $\begin{array}{l}\text { Recharge Rate } \\
\text { (ft/day) }\end{array}$ & $\begin{array}{c}\text { Recharge } \\
\text { Concentration (mg/L) }\end{array}$ \\
\hline 1 & & 0.00038 & 50 \\
\hline 2 & & 0.00076 & 50 \\
\hline 3 & & 0.00113 & 50 \\
\hline 4 & & 0.00151 & 50 \\
\hline 5 & & 0.00189 & 50 \\
\hline 6 & & 0.00227 & 50 \\
\hline 7 & & 0.00264 & 50 \\
\hline 8 & & 0.00302 & 50 \\
\hline 9 & & 0.00340 & 50 \\
\hline 10 & & 0.00378 & 50 \\
\hline 11 & & 0.00415 & 50 \\
\hline 12 & & 0.00453 & 50 \\
\hline 13 & & 0.00491 & 50 \\
\hline 14 & & 0.00529 & 50 \\
\hline 15 & & 0.00566 & 50 \\
\hline 16 & & 0.00604 & 50 \\
\hline 17 & & 0.00642 & 50 \\
\hline 18 & & 0.00680 & 50 \\
\hline$\overline{19}$ & & 0.00717 & 50 \\
\hline Noble Creek Recharge Ponds & & Varies & 0 \\
\hline Golf Course & & 0.009307 & 0 \\
\hline Phase 1 & & 0.00378 (max) & 25 \\
\hline Phase 2 & & 0.00378 (max) & 25 \\
\hline Phase 3 & & 0.00378 (max) & 25 \\
\hline Phase 4 & & $0.00378(\max )$ & 25 \\
\hline Phase 5 & & $0.00378(\max )$ & 25 \\
\hline Additional Recharge Ponds & & Varies & 0 \\
\hline
\end{tabular}




\section{Faults}

Faults in the Beaumont Basin, which result as deformations caused by the San Andreas Fault, constitute the majority of the boundaries of each of the major storage units within the San Gorgonio Pass. Due to their key role in defining the storage unit, faults within the Beaumont Basin have been incorporated into the MODFLOW model. Visual MODFLOW uses the Horizontal Flow Barrier (HFB) package, "... or Wall Boundary as it is referred to in Visual MODFLOW...to

simulate thin, vertical, low-permeability features that impede the horizontal flow of groundwater" (Schlumberger Water Services 2010).

The faults within the model area were assigned in a fashion similar to the layer boundary elevations. Each of the major faults that were given in the USGS SIR in the geologic map in Figure 5 was assigned key features. These features were then assigned relative coordinates with an engineering scale, and these relative coordinates were used to assign a latitude and longitude to each point. These latitudes and longitudes were converted to UTM Zone 11 coordinates, which were then converted to model feet and row and column coordinates. These rows and columns were then drawn in the model space using the Wall Boundary in Visual MODFLOW, and then appropriate cells between these key fault cells were also assigned Wall Boundary criteria. Altogether, there are 7 major faults that are assigned in the model. The hydraulic conductivities of each fault were assigned based on the calibrated conductivities given in Table 10 of the USGS SIR (Rewis, et al. 2006). Each fault is assumed to be $1 \mathrm{ft}$ thick, so that each fault is very thin compared to the thickness of each model cell, maintaining the validity of the Wall Boundary (Schlumberger Water Services 2010). 


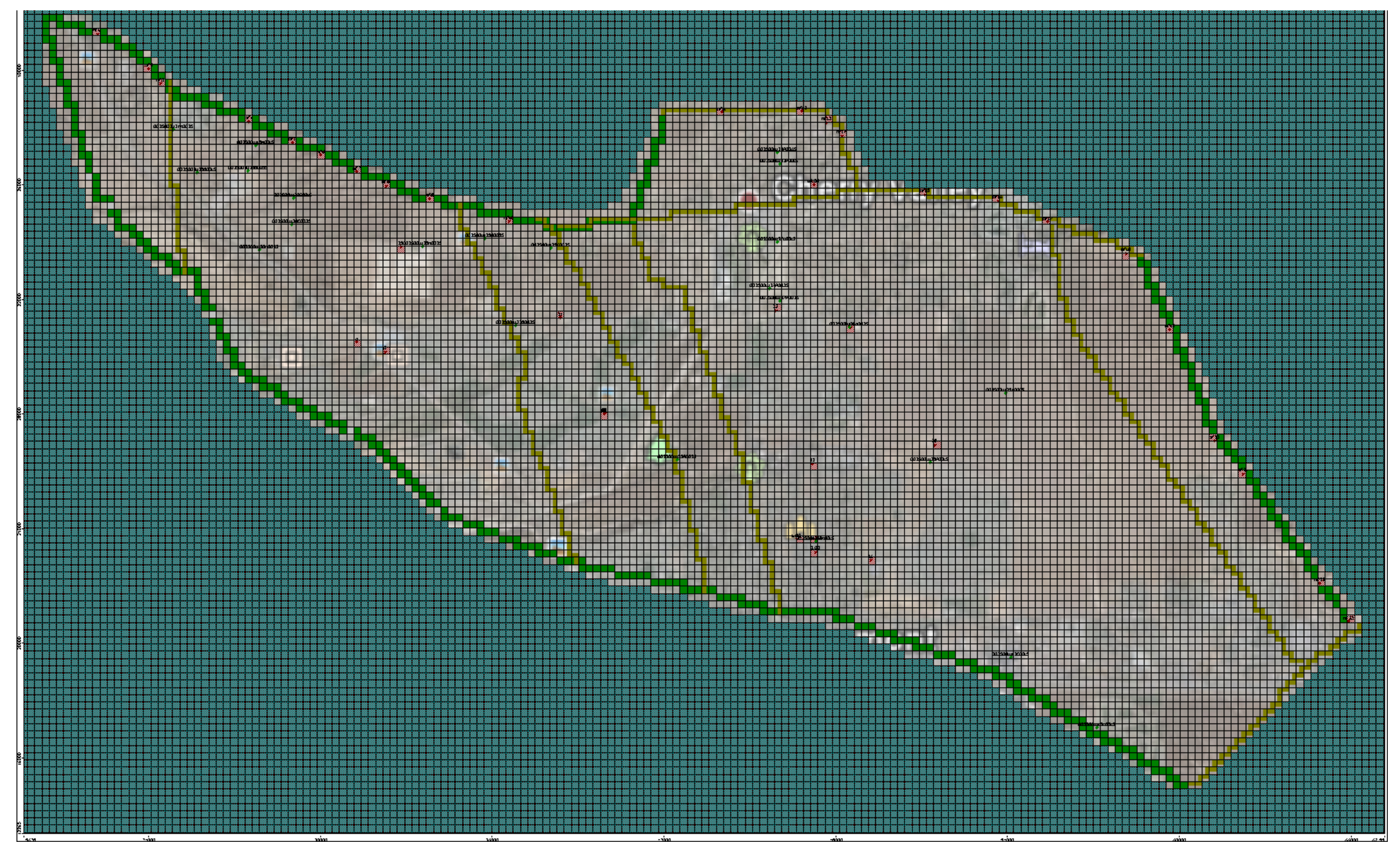

Figure 8: Faults and general head boundaries 


\section{Hydraulic Conductivity}

The hydraulic conductivity of the subsurface soil layers in the Beaumont Basin varies greatly, which makes it somewhat difficult to assign conductivity values for the aquifer. The soil has alternating layers of silt and clay with sand and gravel, making localized areas of increased conductivity and some small regions that act almost as aquitards (Rewis, et al. 2006).

To compensate for the widely varying hydraulic conductivity in the basin, a conductivity estimation scheme was devised for soils near each production well, and data interpolation methods within Visual MODFLOW were used to apply hydraulic conductivity values to the remaining areas of the Beaumont Basin. To begin, production well drilling logs were obtained from the BCVWD for a few of the major production wells managed by the BCVWD. These wells are located throughout the Beaumont Basin, including some wells in the Cherry Valley area, near the Singleton and Edgar Canyon basins, and in the southern portions of the Beaumont Basin, near the South Beaumont basin. Each of these wells has a drilling log, which tracks the type of soil at different depth intervals in the wells. Usually, these logs gave a fairly general idea of the grain size of each soil layer, with little indication of the actual hydraulic conductivity of the soil.

To assign values for the hydraulic conductivity at these wells, the drilling logs were cross referenced with a table of transmissivity values for wells in the Beaumont Basin, transmissivity values developed through pumping tests, and the approximate depths of each major age soil layer in the Beaumont Basin (Rewis, et al. 2006).

Production wells were first assigned elevations, so that the various soil 
layers could be assigned accurately to a major age soil layer. Usually, the production wells had an elevation provided for the ground surface, but in instances where there was no elevation provided, the average elevation of the model cell corresponding to the UTM Zone 11 coordinates of the well was used. Using the drilling logs, each soil layer was assigned a beginning and ending elevation, according to NAVD 88, in feet. Each layer was then assigned to a major age soil layer, based on the beginning and ending elevations of each layer. If a layer spanned multiple model layers, the portion of the soil layer with an elevation in the upper major age layer was assigned to the upper major age layer, and the portion of the soil layer in the lower major age layer was assigned to the lower major age layer.

The approximate grain size of each soil layer in the drilling logs was also recorded, and compared to a standard grain size scale, shown below. The grain sizes are fairly general, with names like, "Gravel," "Gravel with Sand," "Sand," "Sand with Silt," etc. Each grain size and category was then assigned an approximate hydraulic conductivity based on a table of grain sizes and corresponding conductivity values (Bear and Verruijt 1987). The corresponding grain sizes and assumed conductivities for generating effective hydraulic conductivities are shown in Table 3. 
Table 3: Assumed grain sizes and hydraulic conductivities for soil types

\begin{tabular}{|c|c|c|c|}
\hline Soil Class & Code & Conductivity $(\mathrm{cm} / \mathrm{s})$ & Conductivity (ft/day) \\
\hline Gravel & 1 & $\mathbf{0 . 0 2 5}$ & 70.86614173 \\
\hline Gravel and sand & 2 & 0.020615528 & 58.43771753 \\
\hline Sand & 3 & $\mathbf{0 . 0 1 7}$ & 48.18897638 \\
\hline Sand and Silt & 4 & 0.00130384 & 3.695925773 \\
\hline Silt & 5 & $\mathbf{0 . 0 0 0 1}$ & 0.283464567 \\
\hline Silt and Clay & 6 & $3.16228 \mathrm{E}-06$ & 0.008963937 \\
\hline Clay & 7 & $\mathbf{0 . 0 0 0 0 0 0 1}$ & 0.000283465 \\
\hline Hard Clay & 8 & 0.00000001 & $2.83465 \mathrm{E}-05$ \\
\hline Other & 9 & 0.00000001 & $2.83465 \mathrm{E}-05$ \\
\hline
\end{tabular}

The approximate depth of the aquifer was also estimated at each of the wells. The row and column location was determined for each well and the elevations of each interpolated layer were noted. Assuming that groundwater level observation data coincided with the transmissivity tests conducted at each well, the depth of the aquifer at each well was determined to be the elevation of the oldest available ground water level reading minus the lowest major age layer elevation.

Wells with transmissivity data were used to help determine the effective hydraulic conductivity of each major age layer at each well. According to the following equation (De Weist 1969),

$$
T=K b
$$

where

$T=$ Transmisssivity of the aquifer $\left(\mathrm{ft}^{2} / \mathrm{d}\right)$

$K=\quad$ Effective hydraulic conductivity $\left(\mathrm{ft}^{3} / \mathrm{d}\right)$

$b=\quad$ Depth of aquifer $(\mathrm{ft})$

The effective horizontal hydraulic conductivity of each layer is determined 
using an equation where the hydraulic conductivity of each individual layer is weighted by the total depth of each layer (Bear and Verruijt 1987),

$$
K_{e q}^{P}=\frac{1}{B} \sum_{i=1}^{N} \quad K_{i} B_{i}
$$

where

$K_{e q}^{P}=$ Equivalent hydraulic conductivity parallel to the layers in the aquifer $\left(\mathrm{ft}^{3} / \mathrm{d}\right)$

$K_{i}=$ Hydraulic conductivity of the ith soil layer $\left(\mathrm{ft}^{3} / \mathrm{d}\right)$

$B_{i}=$ Depth of the ith soil layer (ft)

$B=$ Total saturated depth of the aquifer $(\mathrm{ft})$

Since there is assumed to be a small layer of low conductivity silts and clays within the Cherry Valley area that creates a perched aquifer, an additional layer was later added to simulate this discontinuity in hydraulic conductivity. A small bottom portion of the top layer (layer 1) was made into a new layer, where the soils in this new layer, north of the Cherry Valley fault and south of the general head boundaries along the north side of the model, were assigned a low conductivity value, with care to provide a lower hydraulic conductivity to the vertical conductivity of the new conductivity zone. The small sliver of what was originally the topmost model layer is referred to as layer 2 within the model, and maintains the same conductivity values and zones as layer 1 , with the exception of the perched region underneath Cherry Valley.

Since these equivalent conductivities may not be completely accurate due to the assumptions made for the grain sizes and hydraulic conductivities of each soil description, the hydraulic conductivity values were adjusted through the calibration process to help meet observed head values. 


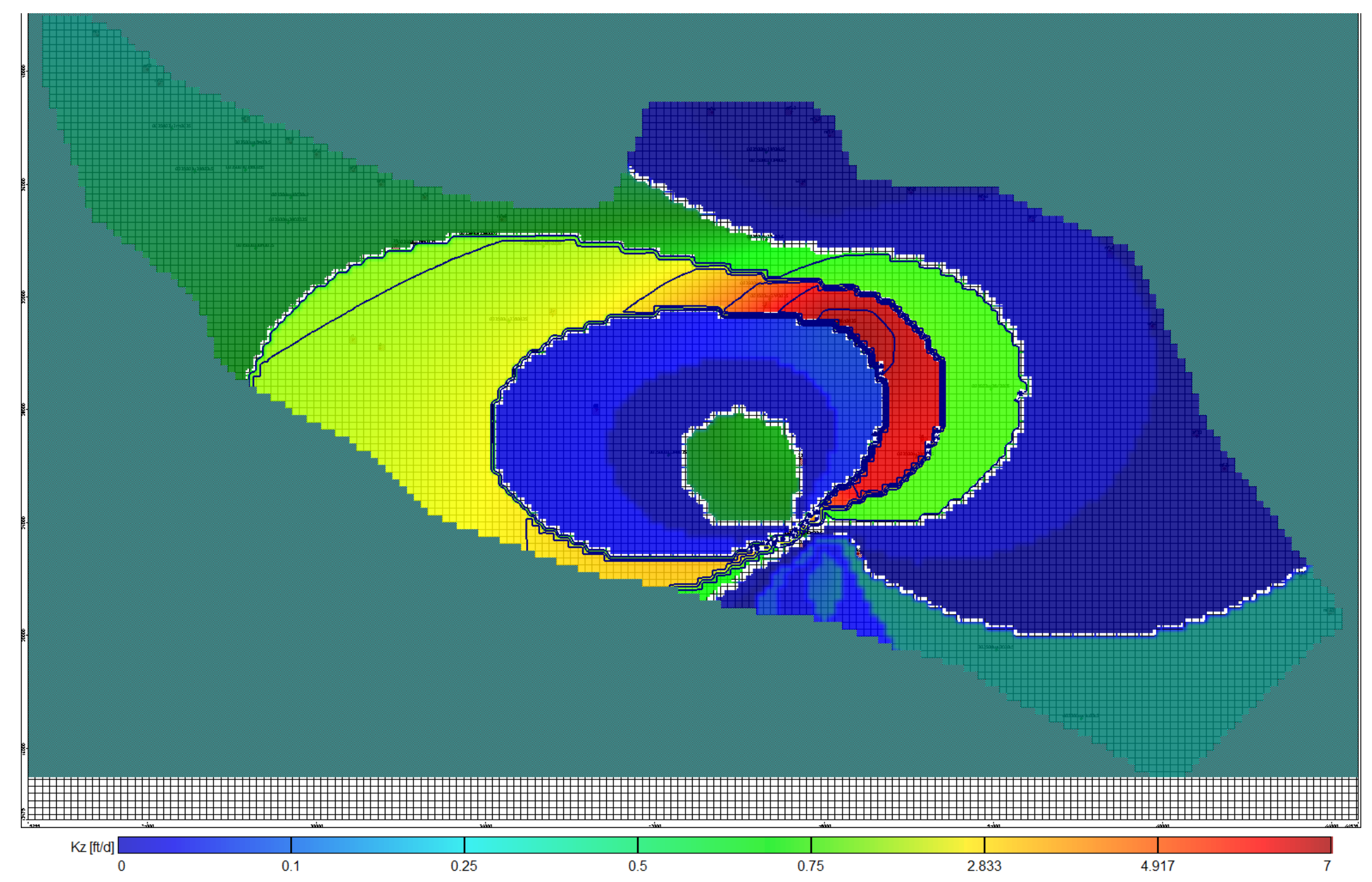

Figure 9: Vertical hydraulic Conductivity in Layer 4 


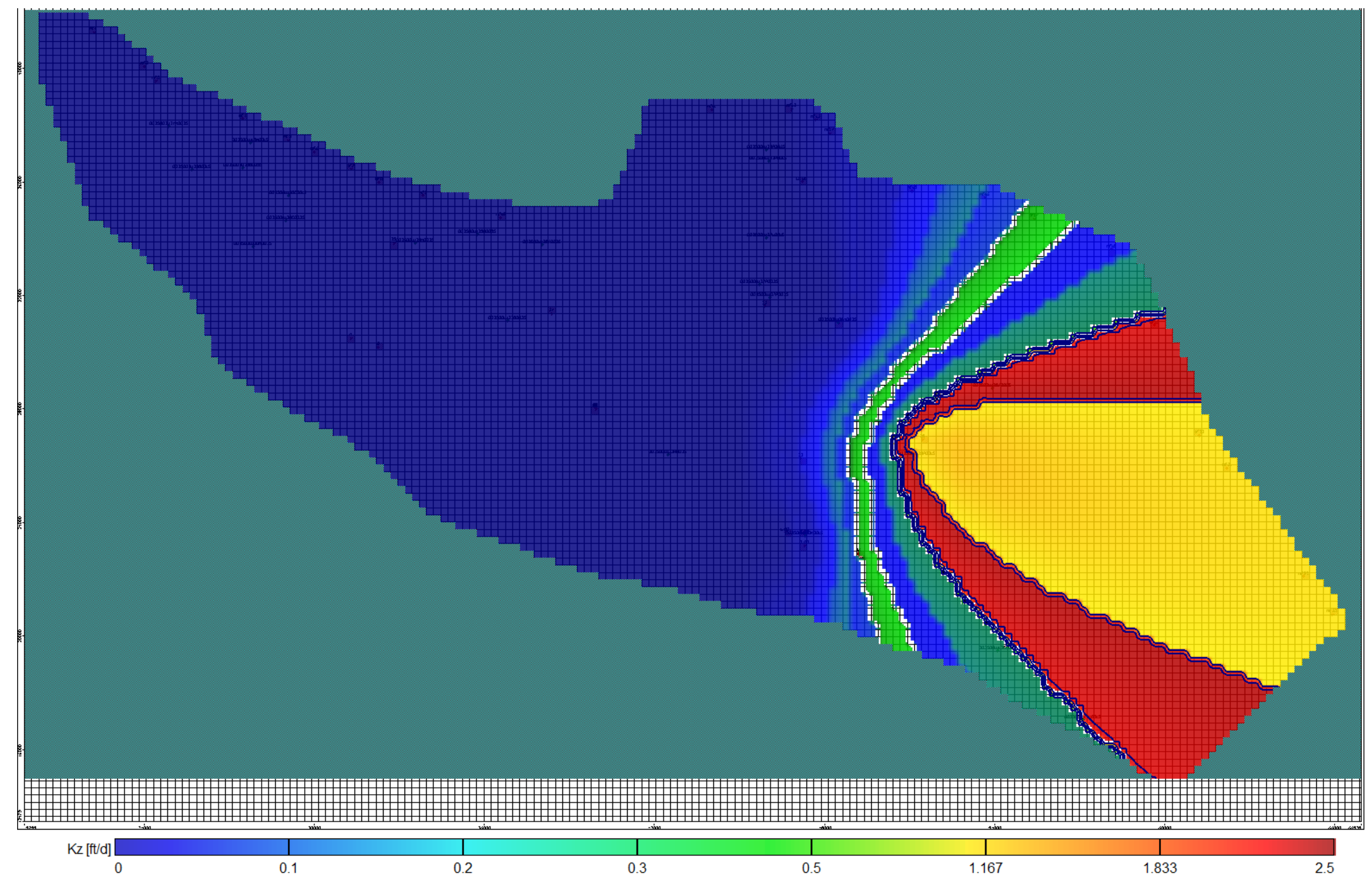

Figure 10: Vertical hydraulic conductivity in Layer 5 


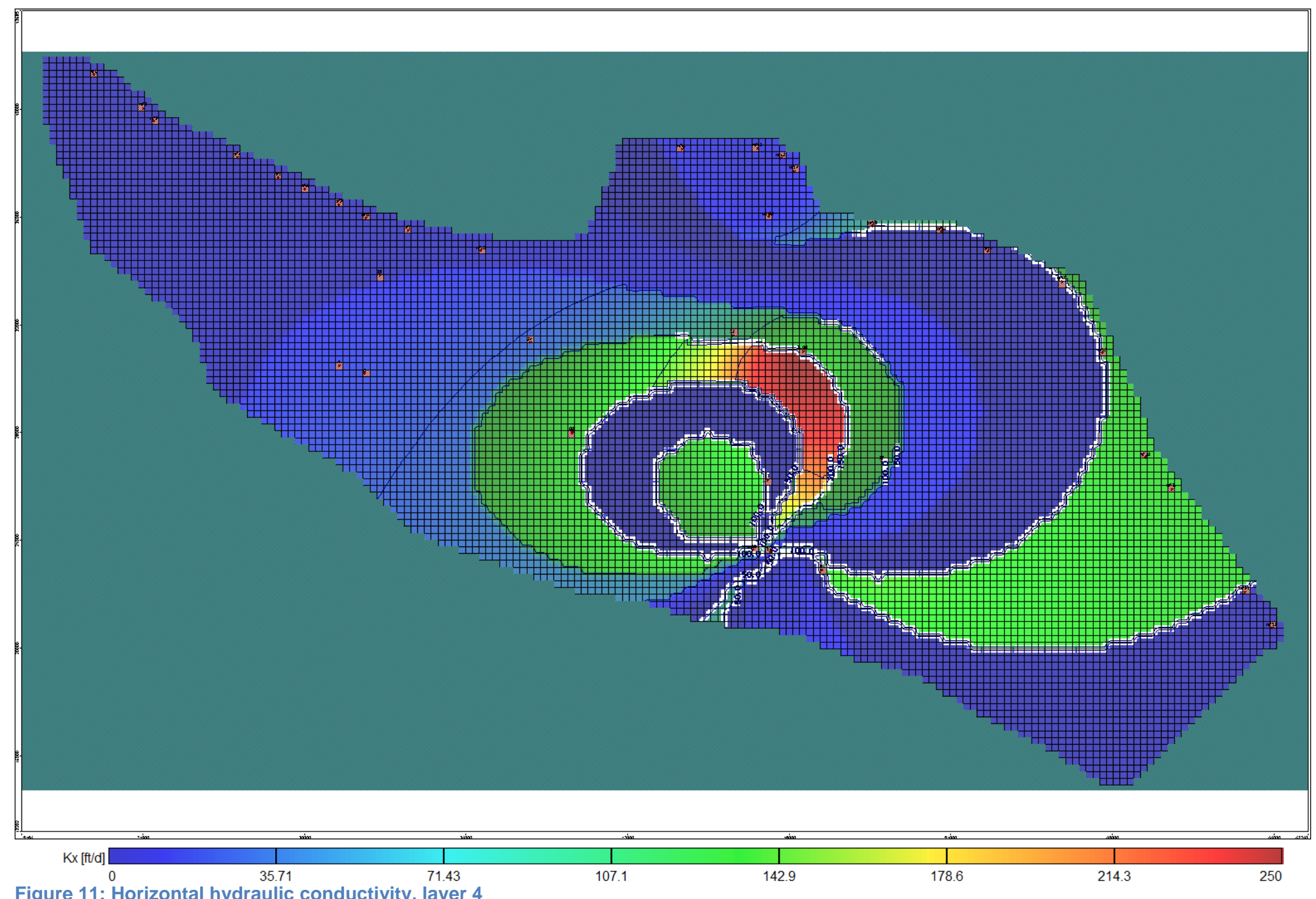




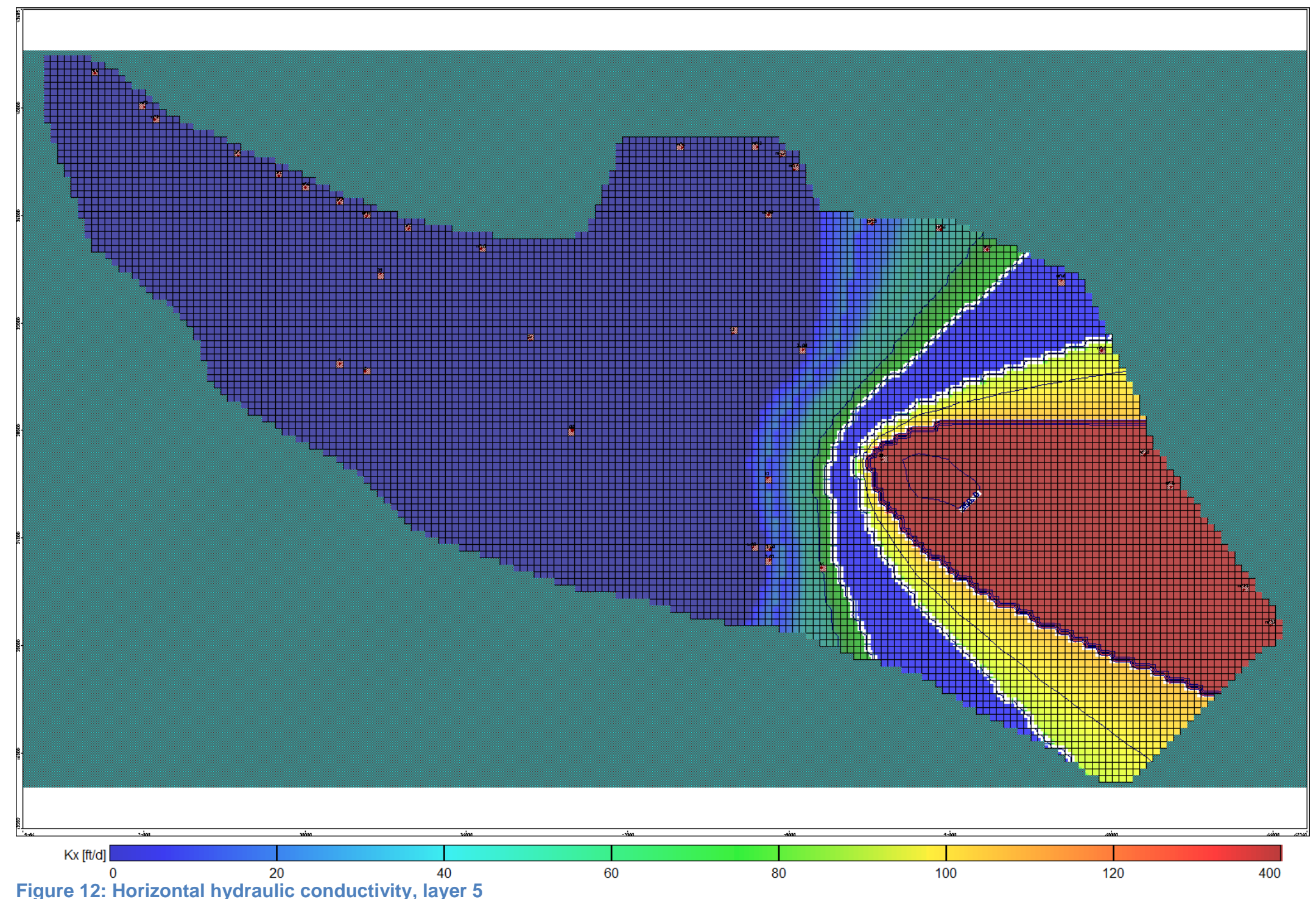




\section{Production Wells}

Visual MODFLOW allows users to add production well data by specifying production well parameters such as location, screen intervals, casing width, and pumping schedules (Schlumberger Water Services 2010). Well properties, such as the screening intervals and casing size, for many of the production wells operated by the BCVWD were obtained from well completion reports (BeaumontCherry Valley Water District 1995). The data for each production well was added to a database file in the proper format to be imported into Visual MODFLOW. Pumping schedules, including pumping volumes for each BCVWD well within the Beaumont Basin (Reichenberger 2012), were later added to the model by converting monthly volumes, in acre-feet, to an average monthly pumping rate in gallons per minute. These values were then added to each individual production well within Visual MODFLOW, so that the pumping data could be used during a transient model and calibration.

Additional annual pumping volumes, in acre-feet, were also provided by the SGPWA for wells owned by the Morongo Band of Indians and Oak Valley Golf Course (Davis and Rasmussen 2011). These wells are private production wells, but they have a significant annual production volume and are located within the Beaumont Basin, meaning that they likely have a substantial effect on the groundwater hydraulics within the Beaumont Basin. As previously discussed, private wells within the Beaumont and surrounding basins are not required to report their annual pumping to the SGPWA unless their pumping volumes exceed 25 acre-feet per year (Davis, Email conversation 2011). For this groundwater model, it is assumed that these private wells contribute a negligible 
effect to the groundwater hydraulics of the Beaumont Basin, especially in comparison to the BCVWD production wells and privately-owned production wells that do pump groundwater on a much larger scale.

The USGS SIR also makes the assumption for inflows of groundwater called "mountain front recharge." This recharge is due to groundwater flowing into the study area along the northern boundary from the Edgar Canyon basin. To account for this recharge, production wells were assigned along the northern boundary of the Beaumont Basin. These production wells injected groundwater, rather than extracting groundwater, at flow rates determined from converting annual volumes determined in the USGS SIR (Rewis, et al. 2006).

The mountain front recharge also contributes nitrate to the Beaumont Basin (University of California, Riverside 2012). To account for these inflows of nitrate, point sources of nitrate were added at the same locations of the mountain front recharge injection wells, and were assigned nitrate concentrations congruent with the estimated inflow of nitrate-nitrogen at 10,000 kg per year.

\section{Storage}

The storage properties of the aquifer were determined from the USGS SIR, which provided calibrated specific storage values for each of 5 main regions of the Beaumont and Banning basins (Rewis, et al. 2006). For all sections of the Beaumont Basin, the specific storage coefficient was set to $1.0 \times 10^{-6}$. The specific yield was set to 0.18 in the Beaumont Basin outside of the Cherry Valley region, and 0.14 within the Cherry Valley region, as shown in Figure 13. These values are presented in the USGS SIR in a summary table of calibrated groundwater model properties. 
The total and effective porosity for the model were assumed to be 0.30 and 0.15 , respectively, for all regions of the Beaumont Basin, as the total porosity, on average, is approximately 0.30 (Flint and Ellett 2004), and the effective porosity is simply assumed to be about half of the total porosity. These values were imported into Visual MODFLOW, and were assigned into property zones using the Natural Neighbors method of interpolation. This generates some variation in the specific storage coefficients in the Beaumont Basin, with a noticeable transition from the south side of the Cherry Valley fault to the north side of the Cherry Valley fault. Since area 3 of the Beaumont Basin is given unique storage values in the USGS SIR, this change in storage is acceptable (Rewis, et al. 2006). 


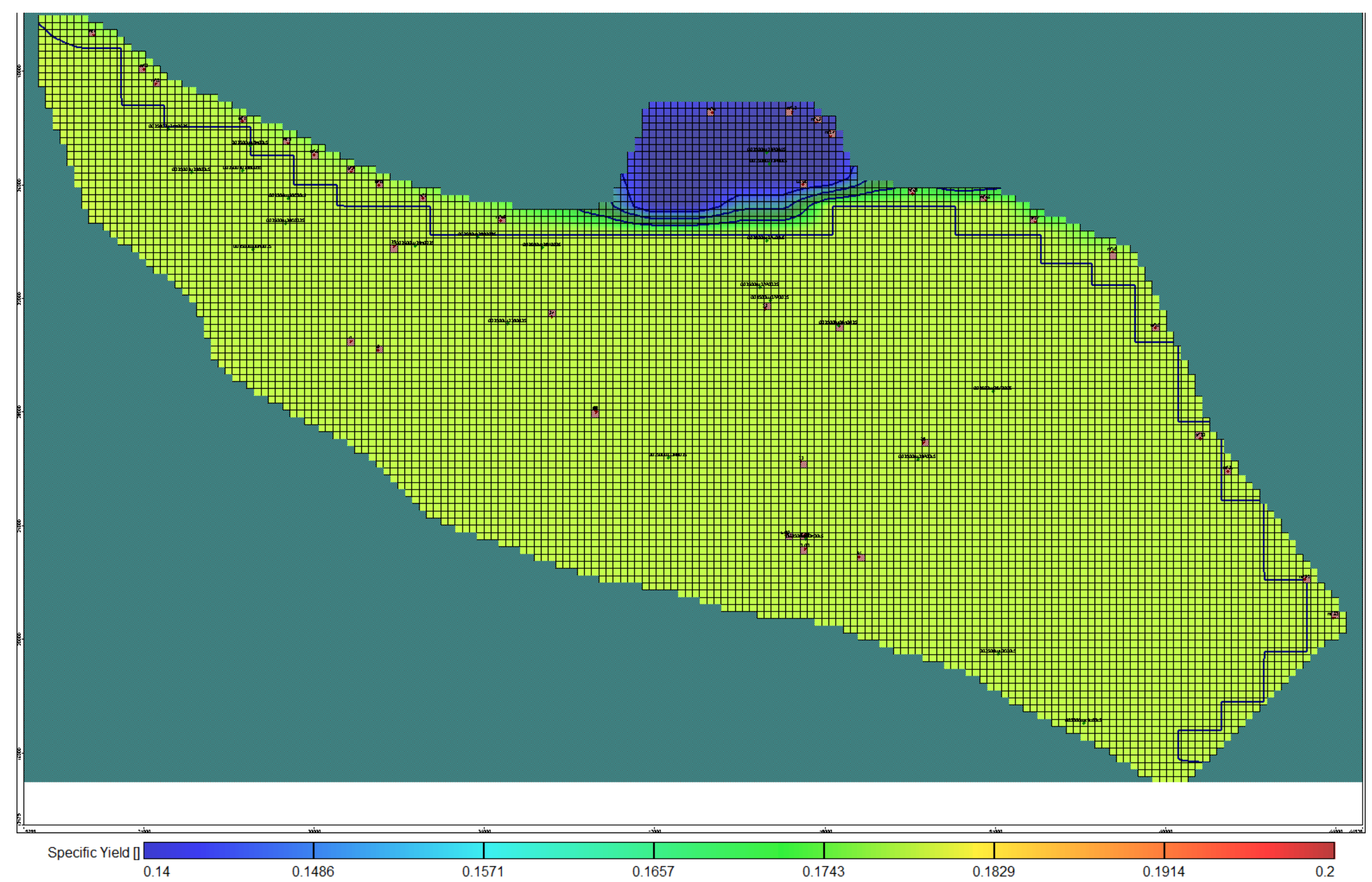

Figure 13: Specific Yield for the Beaumont Basin 


\section{Chapter 5: Data Pre-Processing and Model Building}

In order to build an accurate model of the Beaumont and Cherry Valley areas of the Beaumont Basin, data from several different sources needed to be processed in a way that preserved the scale of different reported and computed hydraulic properties, as well as geologic properties within the Beaumont Basin. This data needed to be scaled consistently, and preserved in a way that allowed for modification in future models.

\section{Spatial Discretization}

To build a spatially accurate depiction of the Beaumont and Cherry Valley area of the San Gorgonio Pass, data was used from both the USGS SIR (Rewis, et al. 2006) and the USGS Seamless Data Warehouse (United States Geological Survey 2010). Figure 5 of the USGS Scientific Investigations Report was used to determine appropriate model extents to capture the entire area of the Beaumont Basin. The latitude and longitude coordinates that captured this extent were latitudes from $34^{\circ} 00^{\prime} 00^{\prime \prime} \mathrm{N}$ to $33^{\circ} 52^{\prime} 30^{\prime \prime} \mathrm{N}$ and longitudes from $117^{\circ} 07^{\prime} 30^{\prime \prime} \mathrm{W}$ to $116^{\circ} 52^{\prime} 30$ "W

These coordinates were used in the Seamless browser to obtain digital elevation model (DEM) files accurate to one third arc second from the National Elevation Dataset. (United States Geological Survey 2010) At a latitude of 34N, one third arc second is approximately $8.53 \mathrm{~m}$ or $28.0 \mathrm{ft}$ in length. (Esri 2011) At this resolution, a MODFLOW model would have a very large number of rows and columns, which would make computation times much longer. This study also does not have access to data that would have any significance on a scale so 
small, so it would not be useful to create a model with a full one third arc second resolution. The original DEM data is also provided with horizontal data according to North American Datum of 1983 (NAD 83) latitude and longitude, making it less ideal for assigning accurate coordinates within MODFLOW. Therefore, the DEM data was edited to make it more manageable and relevant within the model.

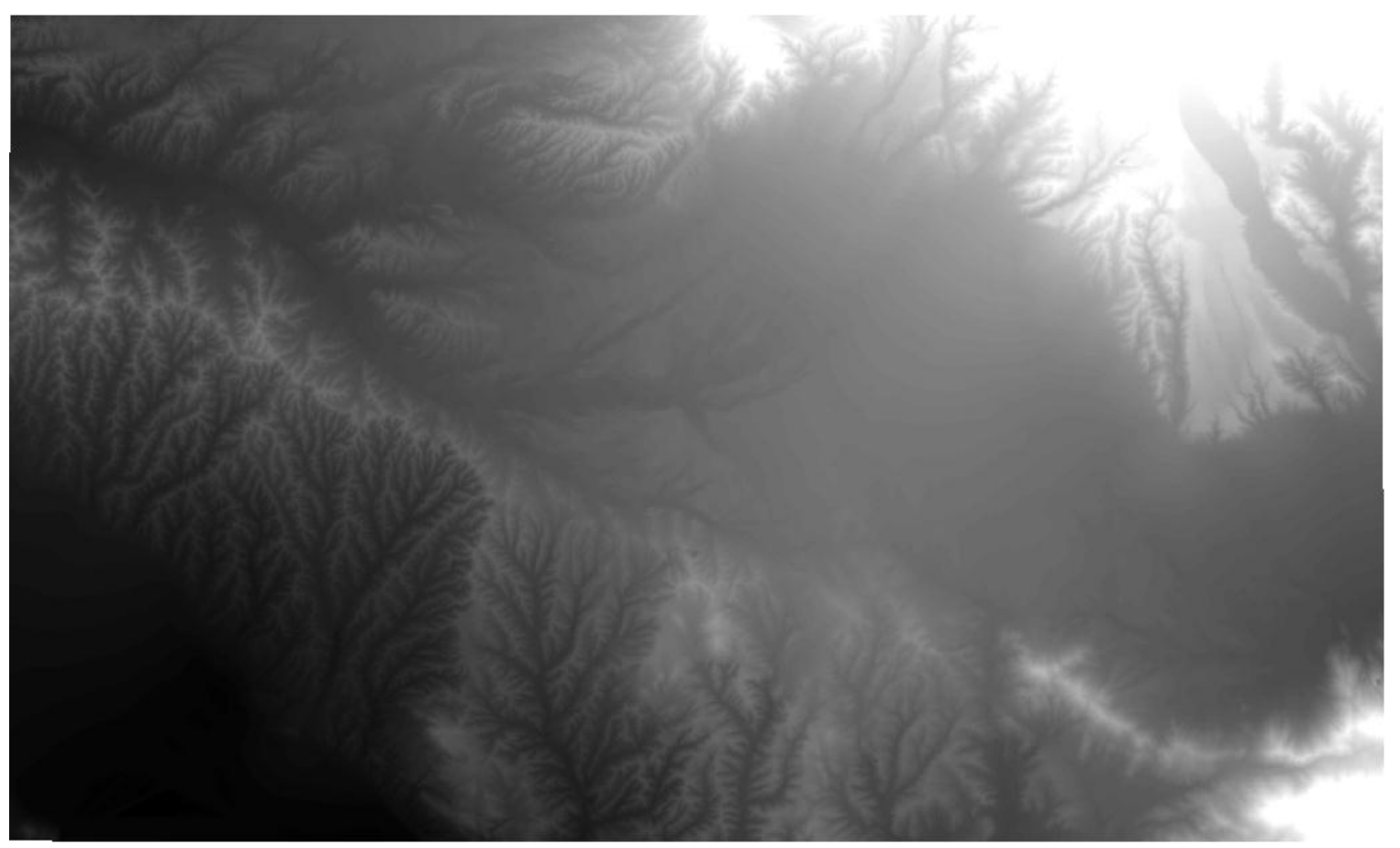

Figure 14: TIFF image of DEM used for assigning Ground Surface Elevation

The software ArcMap 2009 by Esri was used to edit the DEM data. First, the DEM was imported into ArcMap 2009 as a data layer and converted to Universal Transverse Mercator (UTM) Zone 11 coordinates using datum conversion software built into ArcMap. The newly assigned UTM Zone 11 coordinates for the DEM area were northings $3762173.29 \mathrm{~m}$ to $3748296.72 \mathrm{~m}$ and eastings $488439.64 \mathrm{~m}$ to $511567.25 \mathrm{~m}$. The DEM data was then converted to a lower resolution by converting the data within the DEM layer to a Tagged Image File Format (TIFF) image, which had a resolution of 300 cells by 180 cells. 
At this resolution, each cell is approximately $252.93 \mathrm{ft}$ square, making each cell of the model a small enough size to assign data that may pertain to individual homes, but large enough that the computation times for the model would not be extremely long. In converting the original DEM to a TIFF image, the original elevations of each original cell are averaged and assigned to the new cell that replaces these cells in the TIFF image. These elevations are provided in meters above NAVD 88, which is vertical datum used for this model.

To discretize the vertical space of the model, cross sections of Figure 5 from the USGS SIR 2006-5026 (Rewis, et al. 2006) were used to scale and assign coordinates to lower geologic layers. The USGS SIR provides three different cross section views of the geologic layers of the Beaumont Basin, and these cross sections are outlined on a plan view geologic map of the Beaumont Basin. Using an engineering scale and tabloid-sized prints of these cross sections and geologic maps, each major bend and end of the cross sections were assigned coordinates relative to the township and range lines provided in Figure 5 of the USGS SIR. These township and range coordinates were then compared to the latitudes and longitudes indicated on the geologic map. The major features of each cross section were then assigned latitude and longitude coordinates by interpolating between major latitudes and longitudes in Figure 5, using the relative coordinates assigned with the engineering scale.

In each cross section, the vertical elevation is given in feet above NGVD 29, which varies from NAVD 88 by about 3 feet within the coordinates of the model area. Each major feature of the cross section that was located on the plan 
view of the Beaumont Basin was then located on each cross section and the elevation of each boundary between major formation ages was recorded for these major features. Using an engineering scale, each point was scaled so that a more accurate boundary elevation between the major elevations that were provided on the cross section scale could be determined. Using the latitudes and longitudes determined for each key cross section feature, new NAVD 88-based elevations were assigned to each key feature using a conversion tool provided by the National Geodetic Survey (National Geodetic Survey 1999).

Once an elevation had been assigned for each major layer boundary at each key feature, the layer boundaries were imported into Visual MODFLOW using the elevation import tools in the Grid input menu. Since only a few points and elevations had been determined for each layer, the import process utilized the Natural Neighbors method of interpolation to assign elevation values for all cells within the 300 by 180 cell model area. 


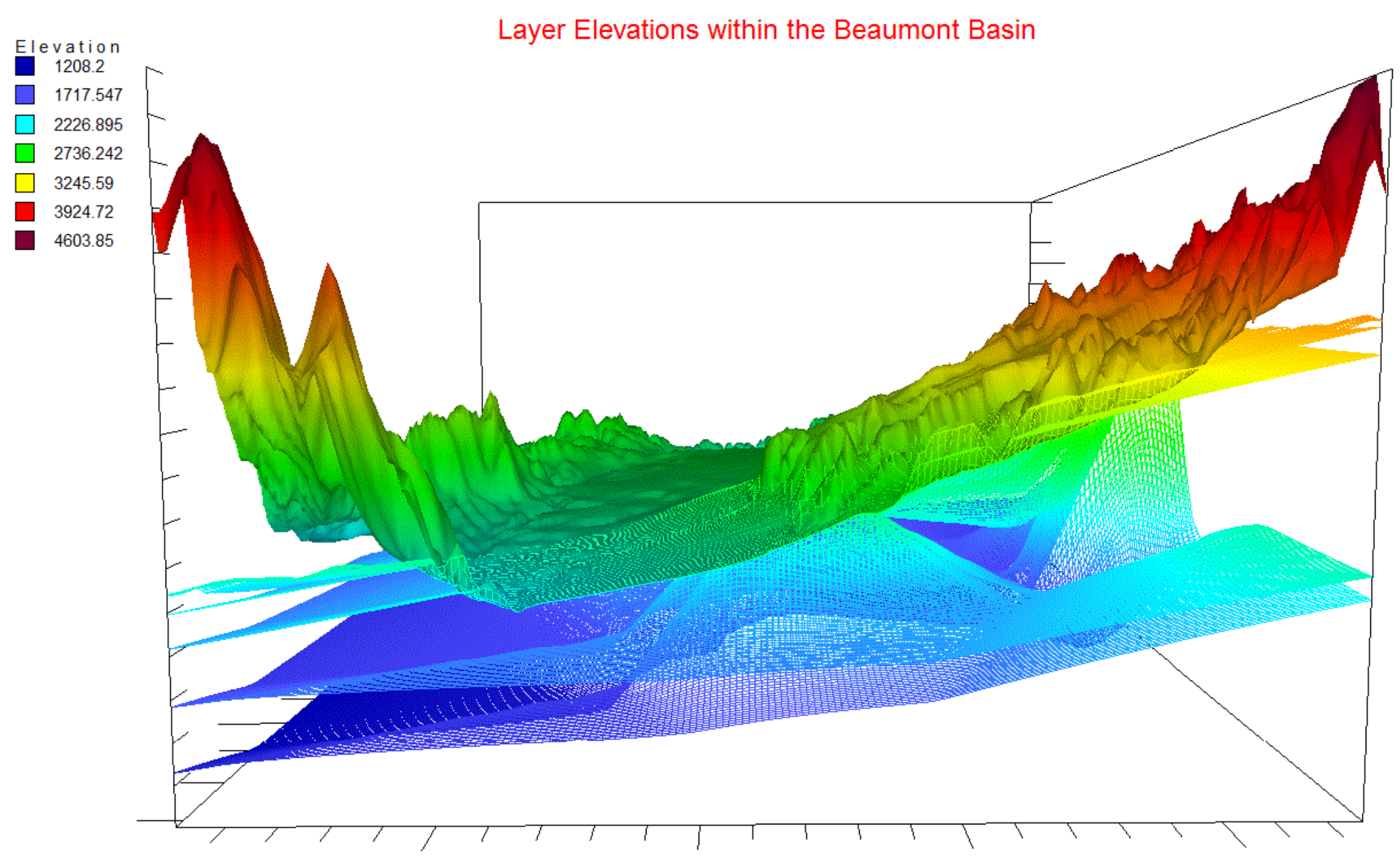

Figure 15: Layer Elevations in the Beaumont Basin, view from East to West 


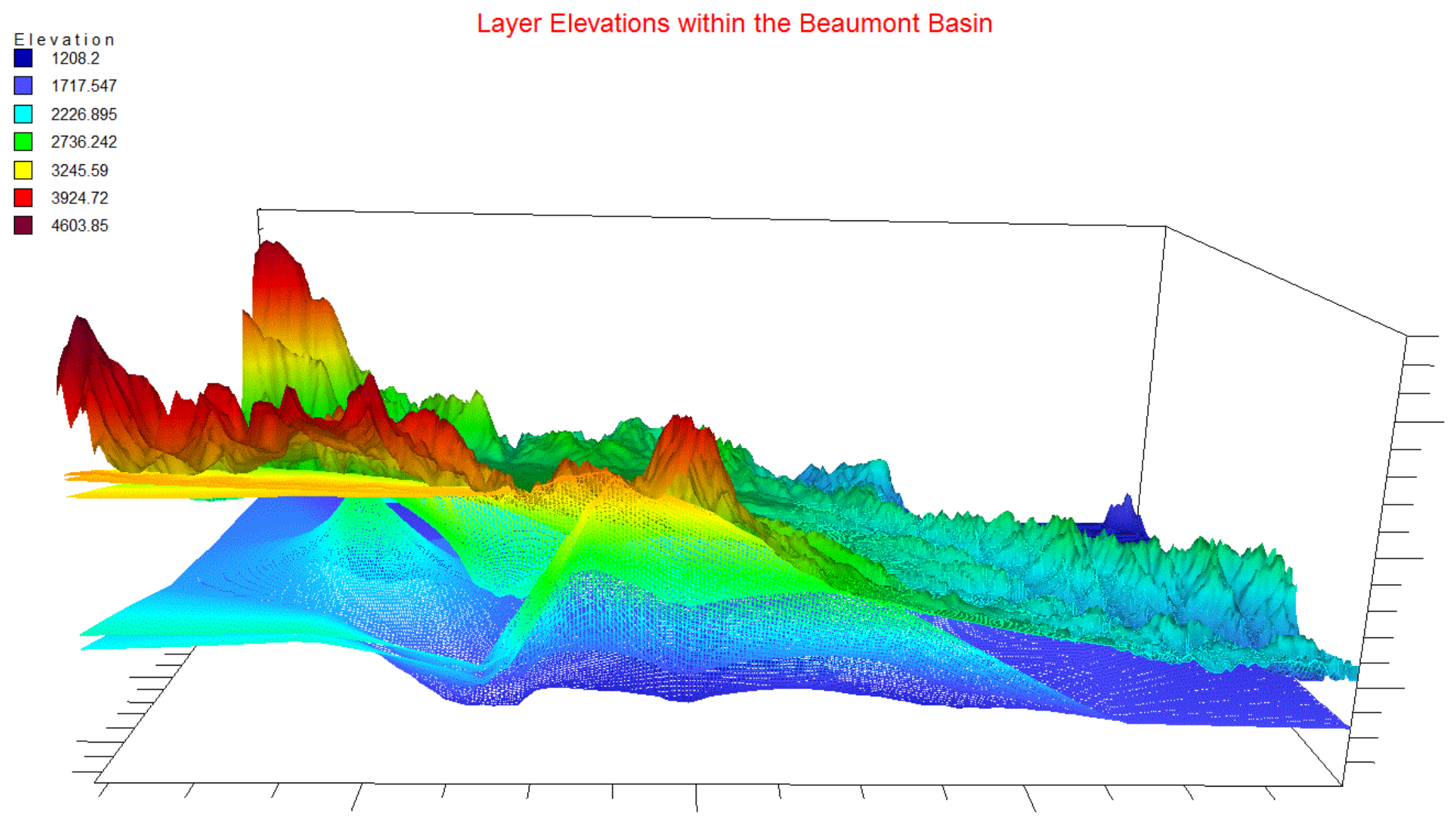

Figure 16: Layer Elevations in the Beaumont Basin, view from North to South 
The process for importing the ground surface into Visual MODFLOW was different from the process used to import the subsurface basin layers. Within ArcMap, the TIFF image of the DEM that had been generated in previous steps was converted into a text file, which could then be opened in Microsoft Excel. Once open, the spreadsheet displays the elevations of each cell in a 300 column by 180 row array, with each of the elevations in meters. The original DEM file is based on NAVD 88, so the values provided in the spreadsheet did not need to be adjusted for a vertical datum shift. Instead, each value in the array was divided by 0.3048 to convert each value from meters to feet. This new array was then copied and pasted into an array editor for the ground surface elevation within Visual MODFLOW, without any additional interpolation scheme.

Once the boundaries of each layer were imported into Visual MODFLOW, they were viewed using the elevation import tool in Visual MODFLOW to confirm that each cell had elevation properties consistent with the geologic maps provided in the USGS SIR (Rewis, et al. 2006).

\section{Conversions from Latitude and Longitude to UTM and Model Coordinates}

Since much of the data used in the model is based on location, it is important to use consistent methods for assigning location coordinates to various data. Since longitudinal distances can decrease in length with an increase in the latitude (Esri 2011), it is important to use a projected datum that will be consistent on a rectangular model plane. Therefore, all data with latitude and longitude coordinates are assigned UTM Zone 11 coordinates, model coordinates, and row and column coordinates in this model. 
Any data that corresponds to latitude and longitude coordinates are assigned a UTM Zone 11 northing and easting based on the methods outlined by Steven Dutch and his provided spreadsheet. The spreadsheet uses methods outlined by the USGS and US Army to make the conversions (Dutch 2011).

The assigned UTM Zone 11 coordinates are then compared to the UTM coordinates of the model extents. The model coordinates of each location are then assigned by interpolating the $\mathrm{x}$ - and $\mathrm{y}$-coordinates based on the $\mathrm{x}$ - and $\mathrm{y}$ coordinates of the model extents. Similarly, row and column coordinates are assigned by interpolating between 1 and 180 rows, and 1 and 300 columns. Any time data are assigned coordinate information, all four forms of location data (latitude/longitude, northing/easting, $\mathrm{x} / \mathrm{y}$, and row/column) are recorded in a Microsoft Access database to preserve the calculations and make data easier to import into Visual MODFLOW.

\section{Observation Wells}

Data about water table levels are a critical component of the groundwater model calibration process, as they allow the modeler to see how well the computed groundwater heads compare to field observations. Observation well data was collected from the USGS by using the USGS site to obtain raw data for observation well readings in the Beaumont and Cherry Valley area (USGS 2011). The data from these areas was then entered into a database which assigned a well name, location information (see Conversions from Latitude and Longitude to UTM and Model Coordinates on page 47), well depth, screen elevation, date of observation, well reading depth, top of well elevation (in NGVD 29 and NAVD 88 coordinates), and a final computed value for the elevation of the observed water 
table for every reported head observation. Using this database of observation information, it is much easier for the modeler to assign initial head conditions and import observation well locations and head values for the duration of a model, especially for different models of the same study area that may consider different years for modeling.

To generate initial head values, the observation well database was used to query for head observations within a small, specific range of days. These observations were then imported into Visual MODFLOW using the Initial Heads import module, using the Natural Neighbors method to interpolate an initial head surface within the model area. This initial head surface is used to define initial conditions for the MODFLOW engine (Schlumberger Water Services 2010). Any observation heads that were located outside of the assumed boundaries of the Beaumont Basin were removed to avoid any issues in the calibration process that might favor observations outside of the Beaumont Basin over those within the basin while assigning new hydraulic conductivity values. Additionally, any observation wells that reflected the perched aquifer in the Cherry Valley area were not used during calibration, as this would often result in high residuals during calibration that may have influenced the calibration of head to observed heads in wells that shared conductivity zones with perched wells in other layers.

\section{Concentration Observation Sites}

While similar to the head observations for the model, the nitrate concentration observation sites proved to be somewhat more challenging to assign due to less available data. Concentration observations available for use within this study include water quality sample data from the BCVWD for many of 
the production wells within the water district. Many wells within the district are sampled about once per year, which makes it difficult to see any short-term fluctuations in the nitrate concentrations. The nitrate concentration data available from the BCVWD was sampled from the Beaumont Basin from March 2, 2005, to December 9, 2010.

When importing initial concentrations into the groundwater model, the initial concentration boundary condition was assigned to each model layer using the Inverse Distance method of interpolation. While the initial concentrations were initially imported into the model space using the Natural Neighbors method like the groundwater head observation data, the small number of observation points prevented a reliable initial concentration array from being interpolated. The Natural Neighbors method generated a distribution of concentrations that appeared to continuously increase into the northeast corner of the Beaumont Basin. While nitrate concentrations are likely to be more elevated towards the northern end of the Beaumont Basin, as this is where the Cherry Valley region is located within the Beaumont Basin, it is much more likely that the circular concentration gradients developed using the Inverse Distance method are a more reliable view of any plumes of nitrate contamination that may be occurring in the Cherry Valley region.

\section{Nitrate Diffusion}

To accurately model the movement of nitrate through the Beaumont Basin, diffusion coefficients reflective of nitrate were assigned to each layer of the model. A value of $1700 \mu \mathrm{m}^{2} / \mathrm{s}$ was found for the diffusion of nitrate in water (M 2009). Since the model units for length and time are feet and days, 
respectively, the diffusion coefficient value was converted to $0.00158 \mathrm{ft}^{2} /$ day. While this value is extremely small, it has been incorporated into the model to help account for any movement of nitrate that may be due to diffusion, however small. 


\section{Chapter 6: Calibration of Visual MODFLOW Models Groundwater Model Calibration}

The calibration process for the model uses the parameter estimation tools provided with the Pro version of Visual MODFLOW (Schlumberger Water Services 2010). All head elevations of the model are compared to the water table elevations, as recorded by the USGS from observation and production wells in and around the Beaumont Basin (USGS 2011). The calibration process adjusts storage and hydraulic conductivity values so that the observed hydraulic head in the Beaumont Basin is consistent with the hydraulic head computed by the Visual MODFLOW model. The model is calibrated over a total period of one year.

Similar to the way Visual MODFLOW provides a way to edit and generate MODFLOW files, Visual MODFLOW also has integration with the PEST-ASP program, which was developed by Dr. John Doherty of Watermark Computing (Watermark Numerical Computing 2010).

During the calibration process, some assumptions were made about the hydraulic conductivity parameters to help lower the calibration time. For each zone of hydraulic conductivity, it was assumed that the horizontal conductivities in both the $\mathrm{x}$ - and $\mathrm{y}$-directions were equal. Thus, the $K_{y}$ values for each conductivity zone in layers 3,4 , and 5 were tied to the $K_{x}$ values for those conductivity zones. By tying these parameters together, PEST will adjust both $K_{x}$ and $K_{y}$ values (Schlumberger Water Services 2010).

In the USGS SIR, the calibrated values for the horizontal conductivity within the Beaumont Basin are 100 times greater than the vertical conductivity 
values (Rewis, et al. 2006). Using this information, prior information was set within the PEST control file so that the horizontal conductivity $\left(K_{x}\right)$ for each conductivity zone would be 100 times greater than the vertical conductivity $\left(K_{z}\right)$ of that same zone. Since the conductivity values were log-transformed in the calibration process, the prior information input was set according to the following scheme:

$$
\log K_{x}-\log K_{z}=2
$$

By tying $K x$ and $K y$ values and indicating that $K X$ values should be 100 times the value of Kz values, PEST calibrated the model to update the values for the hydraulic conductivity array multipliers as shown in Table 4. Table 5 shows the final hydraulic conductivity, in $\mathrm{ft} /$ day, at each of the major production wells in the Beaumont Basin. 
Table 4: Original and Calibrated Hydraulic Conductivity factors

\begin{tabular}{|c|c|c|c|c|c|c|}
\hline & \multicolumn{3}{|c|}{ Original } & \multicolumn{3}{|c|}{ Calibrated } \\
\hline Zone/Layer & $\mathrm{Kx}[\mathrm{ft} / \mathrm{d}]$ & $\mathrm{Ky}[\mathrm{ft} / \mathrm{d}]$ & $\mathrm{Kz}[\mathrm{ft} / \mathrm{d}]$ & $\mathrm{Kx}[\mathrm{ft} / \mathrm{d}]$ & $\mathrm{Ky}[\mathrm{ft} / \mathrm{d}]$ & $\mathrm{Kz}[\mathrm{ft} / \mathrm{d}]$ \\
\hline $1 / 1-2$ & 1 & 1 & 0.1 & 28.68563 & 28.68563 & 286.8563 \\
\hline $2 / 1-2$ & 1 & 1 & 0.1 & 28.68563 & 28.68563 & 286.8563 \\
\hline $3 / 1-2$ & 1 & 1 & 0.1 & 28.68563 & 28.68563 & 286.8563 \\
\hline $4 / 1-2$ & 1 & 1 & 0.1 & 28.68563 & 28.68563 & 286.8563 \\
\hline $5 / 1-2$ & 1 & 1 & 0.1 & 28.68563 & 28.68563 & 286.8563 \\
\hline $6 / 1-2$ & 1 & 1 & 0.1 & 28.68563 & 28.68563 & 286.8563 \\
\hline $7 / 1-2$ & 1 & 1 & 0.1 & 28.68563 & 28.68563 & 286.8563 \\
\hline $8 / 1-2$ & 1 & 1 & 0.1 & 28.68563 & 28.68563 & 286.8563 \\
\hline $9 / 1-2$ & 1 & 1 & 0.1 & 28.68563 & 28.68563 & 286.8563 \\
\hline $10 / 1-2$ & 1 & 1 & 0.1 & 28.68563 & 28.68563 & 286.8563 \\
\hline $11 / 2$ & 1 & 1 & 0.1 & 0.001041 & 0.001041 & 0.004869 \\
\hline $12 / 2$ & 1 & 1 & 0.1 & 0.48327 & 0.48327 & 0.025324 \\
\hline $13 / 2$ & 1 & 1 & 0.1 & 0.355246 & 0.355246 & 1.577941 \\
\hline $14 / 2$ & 1 & 1 & 0.1 & 0.560148 & 0.560148 & 0.010738 \\
\hline $15 / 2$ & 1 & 1 & 0.1 & 0.756284 & 0.756284 & 0.068429 \\
\hline $16 / 2$ & 1 & 1 & 0.1 & 0.776973 & 0.776973 & 0.105444 \\
\hline $17 / 2$ & 1 & 1 & 0.1 & 1.019549 & 1.019549 & 0.104551 \\
\hline $18 / 2$ & 1 & 1 & 0.1 & 0.50376 & 0.50376 & 0.010084 \\
\hline $19 / 2$ & 1 & 1 & 0.1 & 2.189562 & 2.189562 & 0.642939 \\
\hline $20 / 2$ & 1 & 1 & 0.1 & 1.12291 & 1.12291 & 0.05937 \\
\hline $21 / 3$ & 1 & 1 & 0.1 & 0.729662 & 0.729662 & 0.06798 \\
\hline $22 / 3$ & 1 & 1 & 0.1 & 0.885 & 0.885 & 0.025581 \\
\hline $23 / 3$ & 1 & 1 & 0.1 & 0.238314 & 0.238314 & 0.065863 \\
\hline $24 / 3$ & 1 & 1 & 0.1 & 3.211076 & 3.211076 & 0.001 \\
\hline $25 / 3$ & 1 & 1 & 0.1 & 0.174084 & 0.174084 & 0.010087 \\
\hline $26 / 3$ & 1 & 1 & 0.1 & 0.859527 & 0.859527 & 0.291255 \\
\hline $27 / 3$ & 1 & 1 & 0.1 & 2.359968 & 2.359968 & 1.195095 \\
\hline $28 / 3$ & 1 & 1 & 0.1 & 4.552455 & 4.552455 & 0.030062 \\
\hline $29 / 3$ & 1 & 1 & 0.1 & 0.053829 & 0.053829 & 0.008895 \\
\hline $30 / 3$ & 1 & 1 & 0.1 & 3.446026 & 3.446026 & 0.136623 \\
\hline $31 / 4$ & 1 & 1 & 0.1 & 0.016303 & 0.016303 & 0.070141 \\
\hline $32 / 4$ & 1 & 1 & 0.1 & 3.81782 & 3.81782 & 0.04608 \\
\hline $33 / 4$ & 1 & 1 & 0.1 & 2.203533 & 2.203533 & 0.073557 \\
\hline $34 / 4$ & 1 & 1 & 0.1 & 2.460599 & 2.460599 & 0.103317 \\
\hline $35 / 4$ & 1 & 1 & 0.1 & 2.05351 & 2.05351 & 0.060198 \\
\hline $36 / 4$ & 1 & 1 & 0.1 & 2.449864 & 2.449864 & 0.160062 \\
\hline $37 / 4$ & 1 & 1 & 0.1 & 0.534849 & 0.534849 & 0.029996 \\
\hline $38 / 4$ & 1 & 1 & 0.1 & 0.513922 & 0.513922 & 0.063703 \\
\hline $39 / 4$ & 1 & 1 & 0.1 & 2.523819 & 2.523819 & 0.529712 \\
\hline $40 / 4$ & 1 & 1 & 0.1 & 7.619662 & 7.619662 & 0.285755 \\
\hline $41 / 2$ & 0.003139 & 0.003139 & 0.003139 & 0.003139 & 0.003139 & 0.003139 \\
\hline
\end{tabular}


Table 5: Calibrated hydraulic conductivity at production wells, ft/day

\begin{tabular}{|c|c|c|c|c|c|c|c|c|c|c|c|c|c|c|c|}
\hline \multirow[b]{3}{*}{ Well } & \multicolumn{15}{|c|}{ Layer } \\
\hline & \multicolumn{3}{|c|}{1} & \multicolumn{3}{|c|}{2} & \multicolumn{3}{|c|}{3} & \multicolumn{3}{|c|}{4} & \multicolumn{3}{|c|}{5} \\
\hline & $\mathrm{Kx}$ & Ky & $\mathrm{Kz}$ & $\mathrm{Kx}$ & Ky & $\mathrm{Kz}$ & $\mathrm{Kx}$ & Ky & $\mathrm{Kz}$ & $\mathrm{Kx}$ & Ky & $\mathrm{Kz}$ & $\mathrm{Kx}$ & Ky & $\mathrm{Kz}$ \\
\hline $\bar{~} 1$ & $\overline{7.85 \mathrm{E}+02}$ & $7.85 \mathrm{E}+02$ & $7.85 \mathrm{E}+02$ & $7.85 \mathrm{E}+02$ & $7.85 \mathrm{E}+02$ & $7.85 \mathrm{E}+02$ & $2.13 \mathrm{E}+01$ & $2.13 \mathrm{E}+01$ & \begin{tabular}{|c|}
$2.89 \mathrm{E}-01$ \\
\end{tabular} & $1.37 \mathrm{E}+02$ & $1.37 \mathrm{E}+02$ & 9.04E-02 & $.91 \mathrm{E}-02$ & $\begin{array}{l}3.64 \mathrm{E}-02 \\
\end{array}$ & (68E-0 \\
\hline 2 & $7.84 \mathrm{E}+02$ & $7.84 \mathrm{E}+02$ & $7.84 \mathrm{E}+02$ & $7.84 \mathrm{E}+02$ & $7.84 \mathrm{E}+02$ & $7.84 \mathrm{E}+02$ & $2.07 \mathrm{E}+01$ & $2.07 \mathrm{E}+01$ & 1.87E-01 & $2.56 \mathrm{E}+01$ & $2.56 \mathrm{E}+01$ & $8.68 \mathrm{E}-01$ & $2.23 \mathrm{E}+01$ & $2.19 \mathrm{E}+01$ & $69 \mathrm{E}-0$ \\
\hline 3 & $1.04 \mathrm{E}+03$ & $1.04 \mathrm{E}+03$ & $1.04 \mathrm{E}+03$ & $1.04 E+03$ & $1.04 \mathrm{E}+03$ & $1.04 \mathrm{E}+03$ & $2.74 \mathrm{E}+01$ & $2.74 \mathrm{E}+01$ & $2.48 \mathrm{E}-01$ & $8.45 \mathrm{E}+01$ & $8.45 \mathrm{E}+01$ & $2.63 \mathrm{E}-03$ & $2.08 \mathrm{E}+01$ & $2.07 \mathrm{E}+01$ & $2.51 \mathrm{E}-0$ \\
\hline 16 & $6.47 \mathrm{E}+02$ & $6.47 \mathrm{E}+02$ & $6.47 \mathrm{E}+02$ & $3.14 \mathrm{E}-03$ & $3.14 \mathrm{E}-03$ & $3.14 \mathrm{E}-03$ & \begin{tabular}{|l|}
$2.35 \mathrm{E}-02$ \\
\end{tabular} & $2.35 \mathrm{E}-02$ & $1.10 \mathrm{E}-02$ & $3.40 \mathrm{E}+01$ & $3.40 \mathrm{E}+01$ & $1.06 \mathrm{E}-03$ & \begin{tabular}{|l}
$1.63 \mathrm{E}-02$ \\
\end{tabular} & $1.61 \mathrm{E}-02$ & $7.01 \mathrm{E}-0$ \\
\hline 21 & $1.50 \mathrm{E}+03$ & $1.50 \mathrm{E}+03$ & $1.50 \mathrm{E}+03$ & $1.50 \mathrm{E}+03$ & $1.50 \mathrm{E}+03$ & $1.50 \mathrm{E}+03$ & $5.88 \mathrm{E}+01$ & $5.88 \mathrm{E}+01$ & $3.11 \mathrm{E}-01$ & $1.25 \mathrm{E}+02$ & $1.25 \mathrm{E}+02$ & $6.31 \mathrm{E}+00$ & \begin{tabular}{|l|}
$6.02 \mathrm{E}-02$ \\
\end{tabular} & $6.00 \mathrm{E}-02$ & $.59 \mathrm{E}-0$ \\
\hline 22 & $6.85 \mathrm{E}+02$ & $6.85 \mathrm{E}+02$ & $6.85 \mathrm{E}+02$ & $6.85 \mathrm{E}+02$ & $6.85 E+02$ & $6.85 \mathrm{E}+02$ & $1.20 \mathrm{E}+01$ & $1.20 \mathrm{E}+01$ & $2.41 \mathrm{E}-02$ & $2.21 \mathrm{E}+00$ & $2.21 \mathrm{E}+00$ & \begin{tabular}{|c|}
$3.65 \mathrm{E}-02$ \\
\end{tabular} & $2.12 \mathrm{E}+01$ & $2.07 \mathrm{E}+01$ & $7.06 \mathrm{E}-02$ \\
\hline 23 & $1.15 E+03$ & $1.15 \mathrm{E}+03$ & $1.15 \mathrm{E}+03$ & $1.15 E+03$ & 1.15E+03 & $1.15 \mathrm{E}+03$ & $4.08 \mathrm{E}+01$ & $4.08 \mathrm{E}+01$ & $4.18 \mathrm{E}-01$ & $9.19 \mathrm{E}+01$ & $9.19 \mathrm{E}+01$ & $4.65 \mathrm{E}+00$ & 3.11E-05 & 3.00E-05 & 1.34E-05 \\
\hline 24 & $7.87 \mathrm{E}+02$ & $7.87 \mathrm{E}+02$ & $7.87 \mathrm{E}+02$ & $7.87 \mathrm{E}+02$ & 7.87E+02 & $7.87 \mathrm{E}+02$ & $1.54 \mathrm{E}+01$ & $1.54 \mathrm{E}+01$ & 2.95E-02 & $5.14 \mathrm{E}+01$ & $5.14 \mathrm{E}+01$ & $2.60 \mathrm{E}+00$ & 1.63E-10 & 1.63E-10 & $7.01 \mathrm{E}-10$ \\
\hline 25 & $1.14 \mathrm{E}+03$ & $1.14 \mathrm{E}+03$ & $1.14 \mathrm{E}+03$ & $1.14 \mathrm{E}+03$ & $1.14 \mathrm{E}+03$ & $1.14 \mathrm{E}+03$ & $2.01 \mathrm{E}+01$ & $2.01 \mathrm{E}+01$ & $4.02 \mathrm{E}-02$ & $1.03 \mathrm{E}+02$ & $1.03 \mathrm{E}+02$ & $5.23 \mathrm{E}+00$ & $3.41 \mathrm{E}+02$ & $3.41 \mathrm{E}+02$ & $1.28 \mathrm{E}+00$ \\
\hline 26 & $1.31 \mathrm{E}+03$ & $1.31 \mathrm{E}+03$ & $1.31 \mathrm{E}+03$ & $1.31 \mathrm{E}+03$ & $1.31 \mathrm{E}+03$ & $1.31 \mathrm{E}+03$ & $2.30 \mathrm{E}+01$ & $2.30 \mathrm{E}+01$ & 4.60E-02 & $1.33 \mathrm{E}+02$ & $1.33 \mathrm{E}+02$ & $4.14 \mathrm{E}-03$ & $5.75 \mathrm{E}+01$ & $5.75 \mathrm{E}+01$ & $3.76 \mathrm{E}-01$ \\
\hline 29 & $7.30 \mathrm{E}+02$ & $7.30 \mathrm{E}+02$ & $7.30 \mathrm{E}+02$ & 7.30E+02 & $7.30 \mathrm{E}+02$ & $7.30 \mathrm{E}+02$ & $9.04 \mathrm{E}+00$ & $9.04 \mathrm{E}+00$ & $4.02 \mathrm{E}+00$ & $1.33 \mathrm{E}+01$ & $1.33 \mathrm{E}+01$ & $4.52 \mathrm{E}-01$ & 1.63E-10 & $1.63 \mathrm{E}-10$ & 7.01E-10 \\
\hline A & $8.10 E+02$ & $8.10 \mathrm{E}+02$ & $8.10 E+02$ & $8.10 \mathrm{E}+02$ & $8.10 E+02$ & $8.10 \mathrm{E}+02$ & $1.00 \mathrm{E}+01$ & $1.00 \mathrm{E}+01$ & $4.45 \mathrm{E}+00$ & $4.15 \mathrm{E}+01$ & $4.15 \mathrm{E}+01$ & $2.10 \mathrm{E}+00$ & 1.63E-10 & $1.63 \mathrm{E}-10$ & 7.01E-10 \\
\hline D & $8.15 E+02$ & $8.15 \mathrm{E}+02$ & $8.15 \mathrm{E}+02$ & $8.15 E+02$ & $8.15 E+02$ & $8.15 \mathrm{E}+02$ & $1.01 \mathrm{E}+01$ & $1.01 \mathrm{E}+01$ & $4.48 \mathrm{E}+00$ & $4.31 \mathrm{E}+01$ & $4.31 E+01$ & $2.18 \mathrm{E}+00$ & 1.63E-10 & 1.63E-10 & $7.01 \mathrm{E}-10$ \\
\hline G1 & $8.72 E+02$ & $8.72 \mathrm{E}+02$ & $8.72 E+02$ & $8.72 \mathrm{E}+02$ & $8.72 E+02$ & $8.72 \mathrm{E}+02$ & $2.30 \mathrm{E}+01$ & $2.30 \mathrm{E}+01$ & $2.08 \mathrm{E}-01$ & $1.26 \mathrm{E}+02$ & $1.26 \mathrm{E}+02$ & $8.32 \mathrm{E}-02$ & $1.63 \mathrm{E}-10$ & 1.63E-10 & $7.01 \mathrm{E}-10$ \\
\hline $\mathrm{G} 2$ & $8.72 E+02$ & $8.72 \mathrm{E}+02$ & $8.72 E+02$ & $8.72 \mathrm{E}+02$ & $8.72 \mathrm{E}+02$ & $8.72 \mathrm{E}+02$ & $2.30 \mathrm{E}+01$ & $2.30 \mathrm{E}+01$ & $2.08 \mathrm{E}-01$ & $1.26 \mathrm{E}+02$ & $1.26 \mathrm{E}+02$ & 8.32E-02 & $1.63 \mathrm{E}-10$ & $1.63 \mathrm{E}-10$ & $7.01 \mathrm{E}-1$ \\
\hline
\end{tabular}


Originally, the model was calibrated using all available observation head values for the Beaumont Basin and some of the surrounding areas. However, these data proved to skew some of the calibrated values of the hydraulic conductivity within certain property zones of the model.

For example, some of the observation head elevations in the Cherry Valley region reflect head elevations for the local perched aquifer, while others are head elevations for observation wells that penetrate the perched aquifer, and thus are more congruent with the head elevations seen throughout the rest of the Beaumont Basin. The difference in elevation for some wells in the Cherry Valley region can be up to 85 feet, even over a very small area, which can cause issues when attempting to generate calibrated hydraulic conductivities for a continuous groundwater head elevation. For this reason, observation wells that appear to provide head elevations for the perched aquifer in Cherry Valley were eliminated from the calibration process.

Additionally, the original model calibration used observation wells that were located just outside the general head boundaries of the Beaumont Basin. These observation values were later eliminated for future model calibrations since they may be reflective of varying geology in adjacent basins, rather than the Beaumont Basin. For example, wells in the Edgar Canyon basin, north of the Cherry Valley region in the Beaumont Basin, may have elevation heads that reflect the local geology of the Edgar Canyon basin, rather than that of the Beaumont Basin, or these elevation heads may also be affected by the perched layer within the Cherry Valley area. To the south, there were a few observation 
wells located in the San Timoteo and South Beaumont Basins. Since this model seeks to develop an accurate depiction of the Beaumont Basin specifically, it would be unwise to include elevation head observations from adjacent groundwater basins.

After the calibration was complete, the observed head elevations were compared to the head elevations calculated by the model. When plotted at calculated vs. observed values, the calibration points for head used in the 379 day model generally have a strong positive correlation above 0.90 . Figure 16 and Figure 17 below show these plots for days 0.07 and 379 , respectively. It is important to note that, even after calibration, the calculated heads for many wells are higher than the observed heads for specific locations within the study area. While the calibration process did improve the correlation between the calculated and observed head values and reduced the residuals between calculated and observed values, the calibration of each conductivity property zone did not result in a perfect match between calculated and observed heads. 


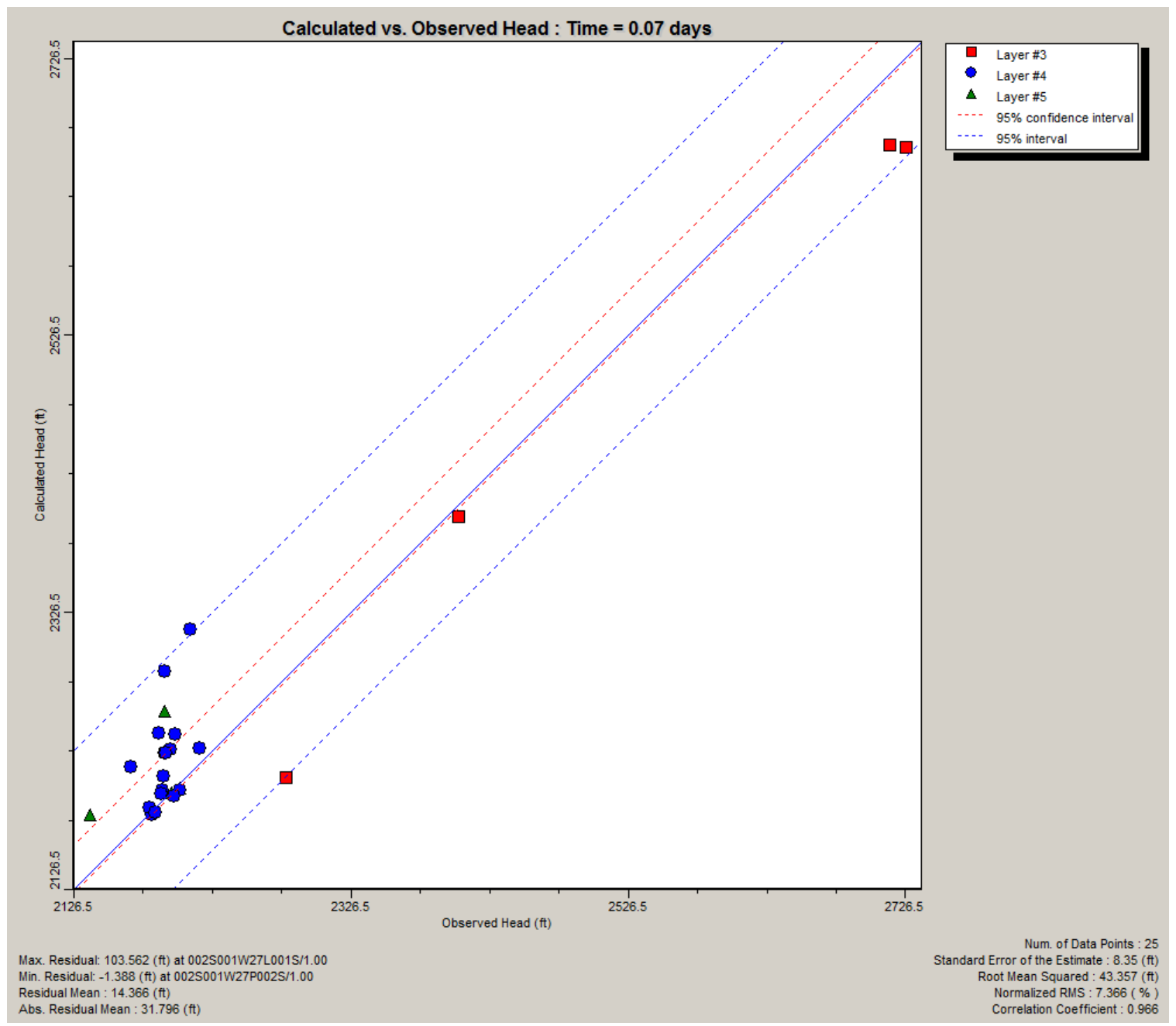

Figure 17: Calculated vs. Observed Heads for 379 Day model, at 0.07 Days 


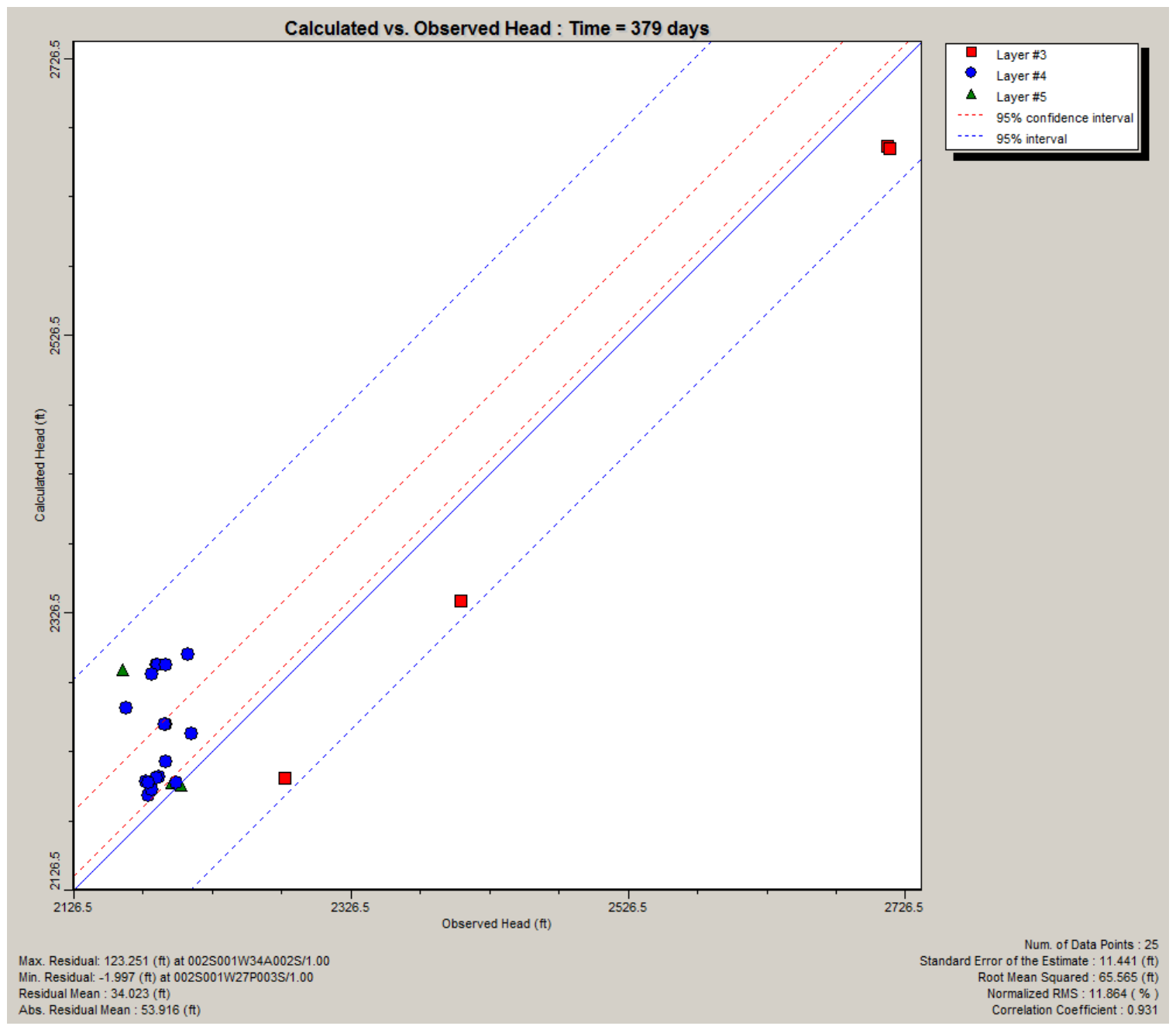

Figure 18: Calculated vs. Observed Heads for 379 Day model, at day 379 


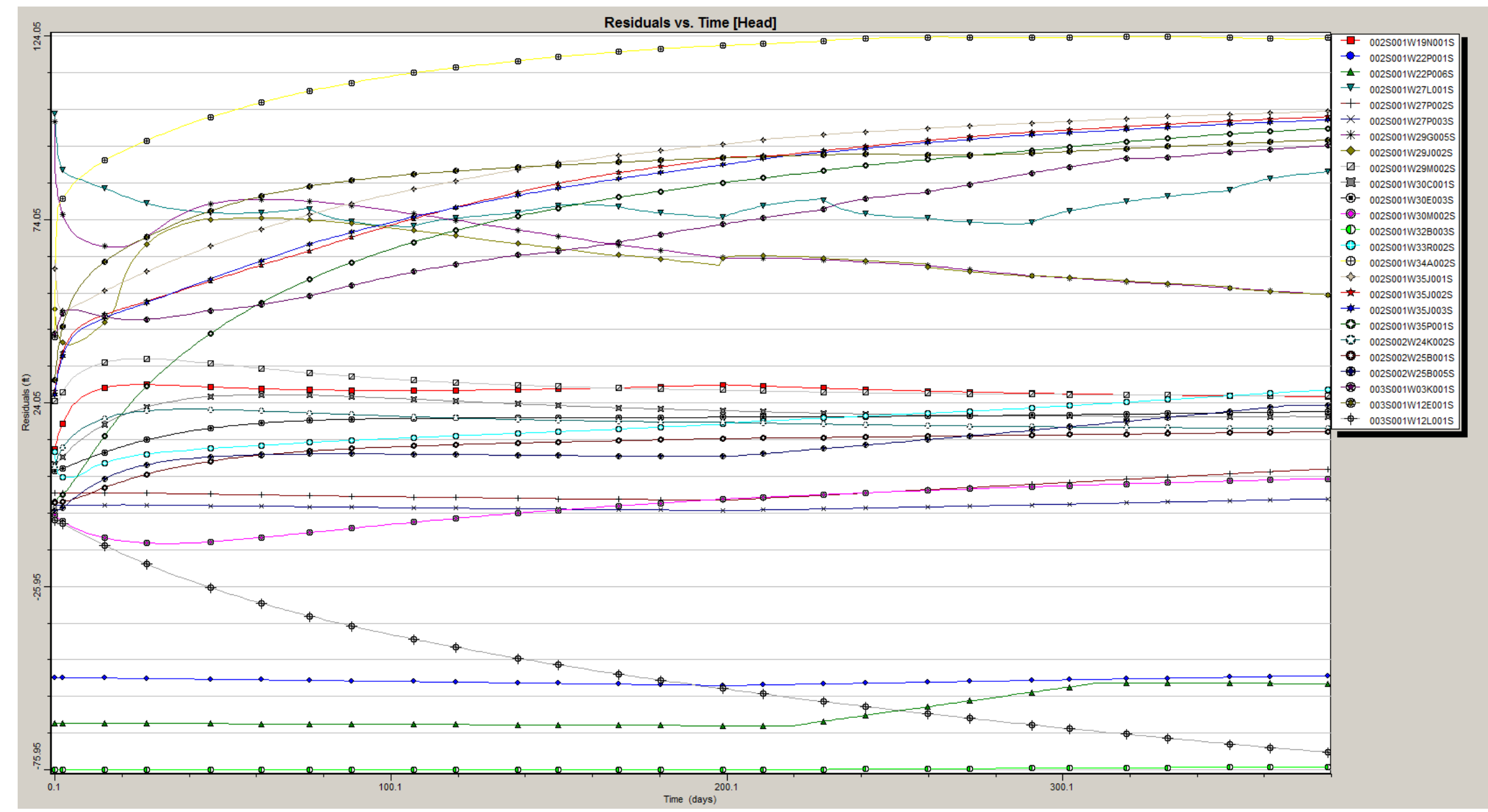

Figure 19: Residuals vs. time, 379 day model 


\section{Data Validation}

To ensure that the model created and calibrated within Visual MODFLOW Pro was adequate for the project area, several models of the Beaumont Basin were run using historical data.

One alternative model uses data from November 2006 through July 2010. This time period reflects provided data for SWP water deliveries to the Noble Creek Recharge Project ponds (Reichenberger 2012). Any variation in production well pumping rates was also reflected for this time period. Once run, the model was compared to observation well data taken during the same time period. These data showed that the hydraulic conductivity values for the model generated fairly good results, with correlation coefficients from 0.895 to 0.919 . The residual values for this model run varied between $-290.20 \mathrm{ft}$ and $207.94 \mathrm{ft}$, though most of the calibration points had residuals with a range between $-65 \mathrm{ft}$ and $100 \mathrm{ft}$, suggesting an improved overall fit for the model area. 


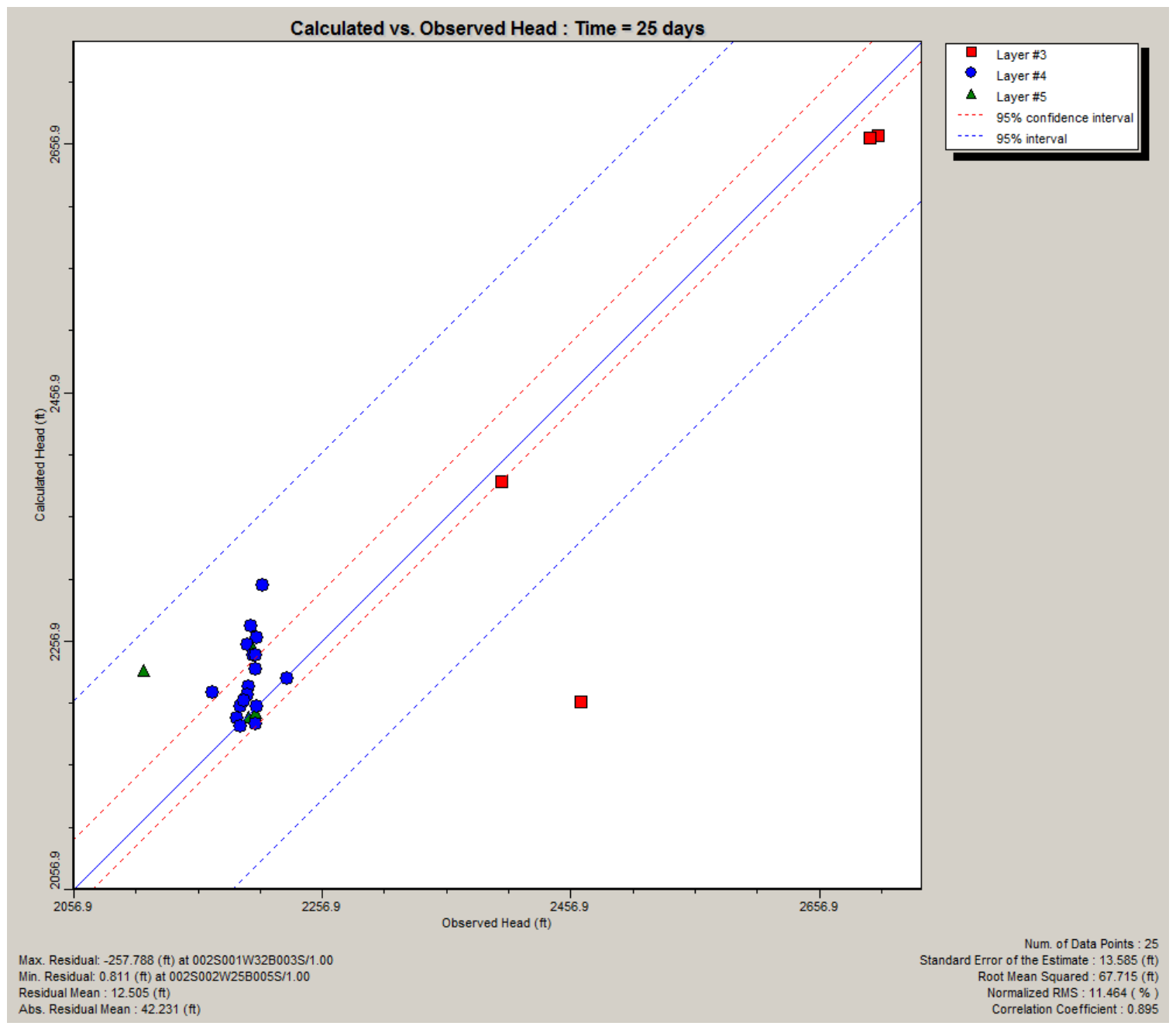

Figure 20: Calculated vs. Observed head, 1278 day model, Day 25 


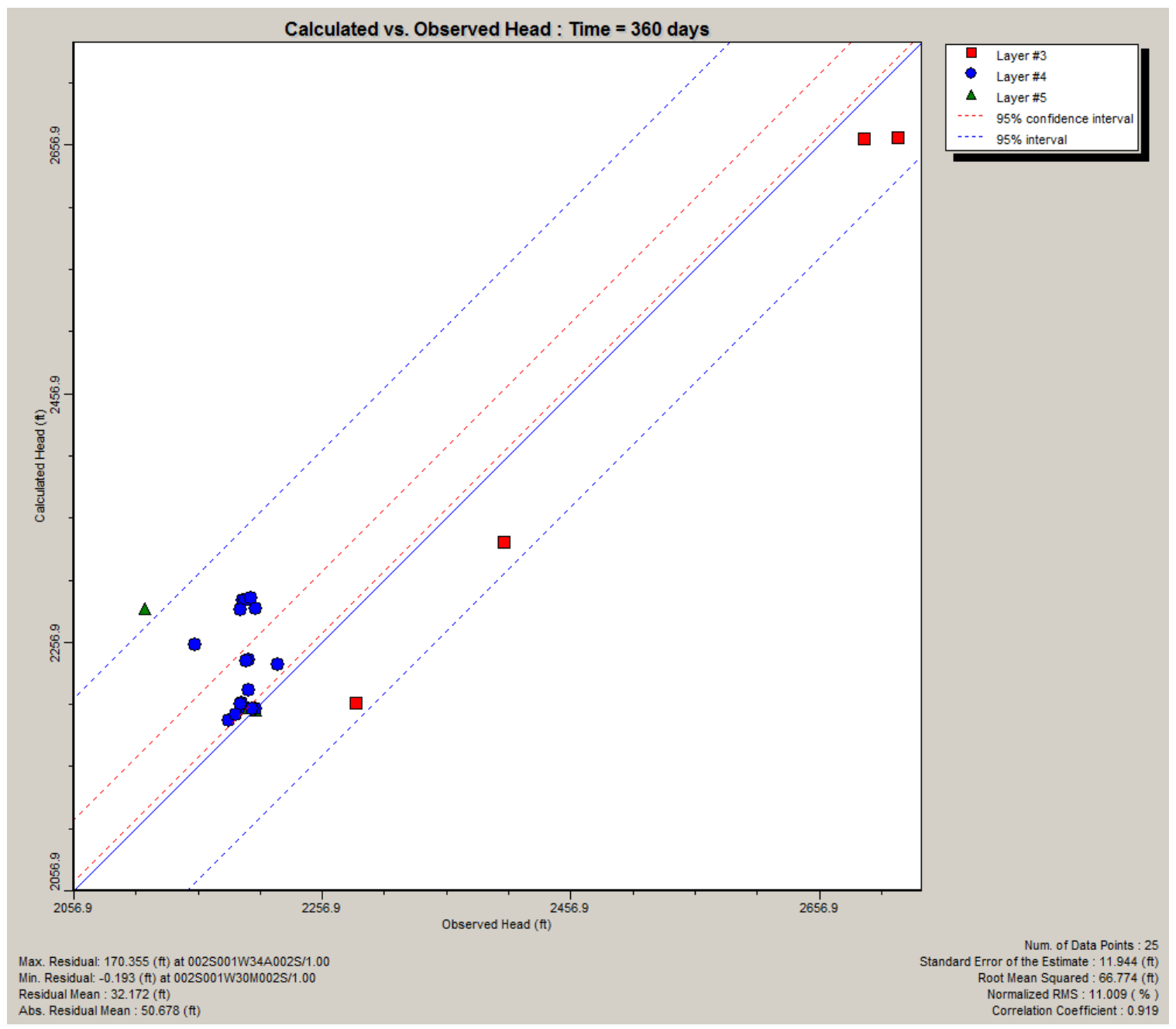

Figure 21: Calculated vs. Observed head, 1278 day model, day 360 


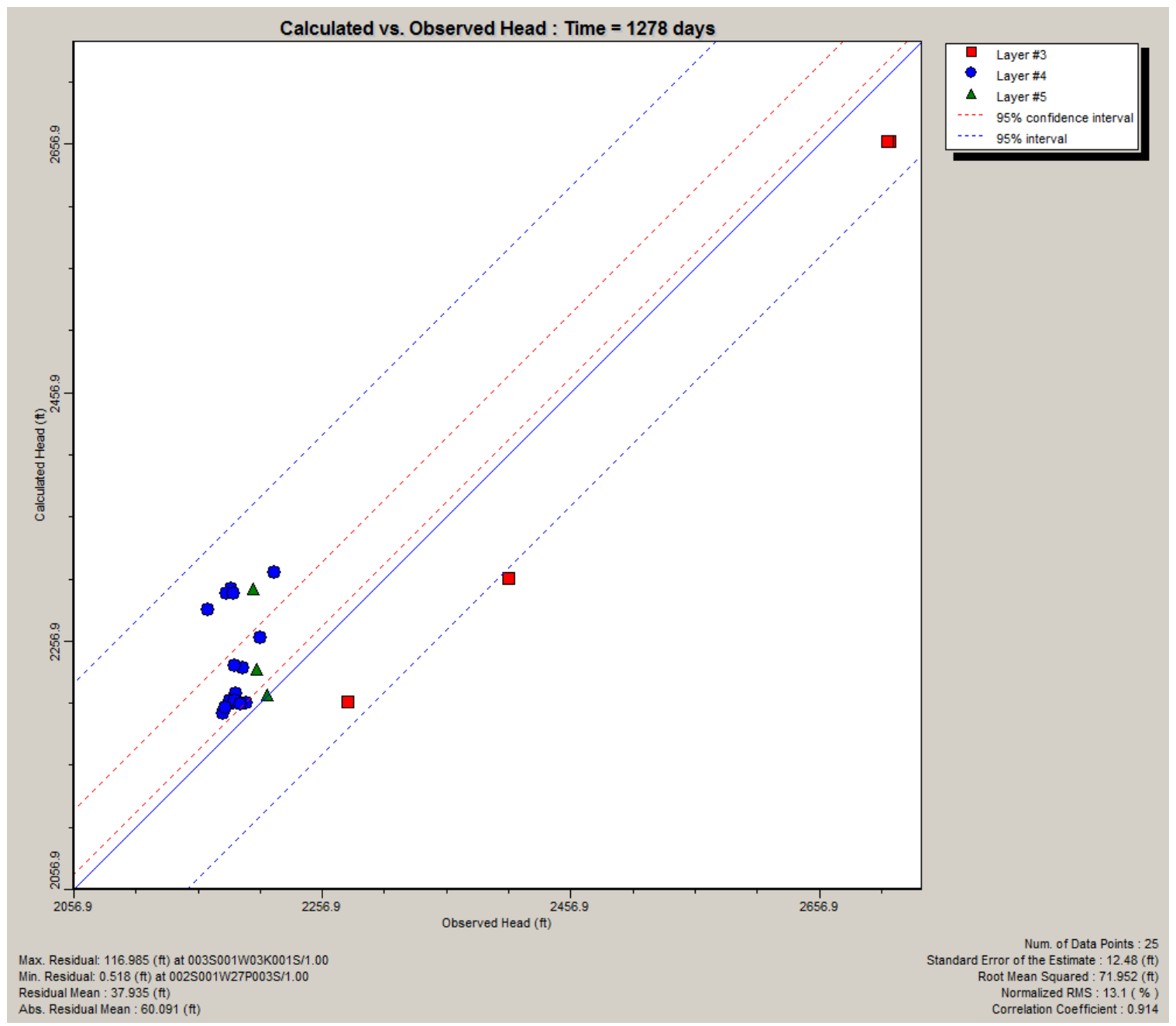

Figure 22: Calculated vs. Observed head, 1278 day model, day 1278 


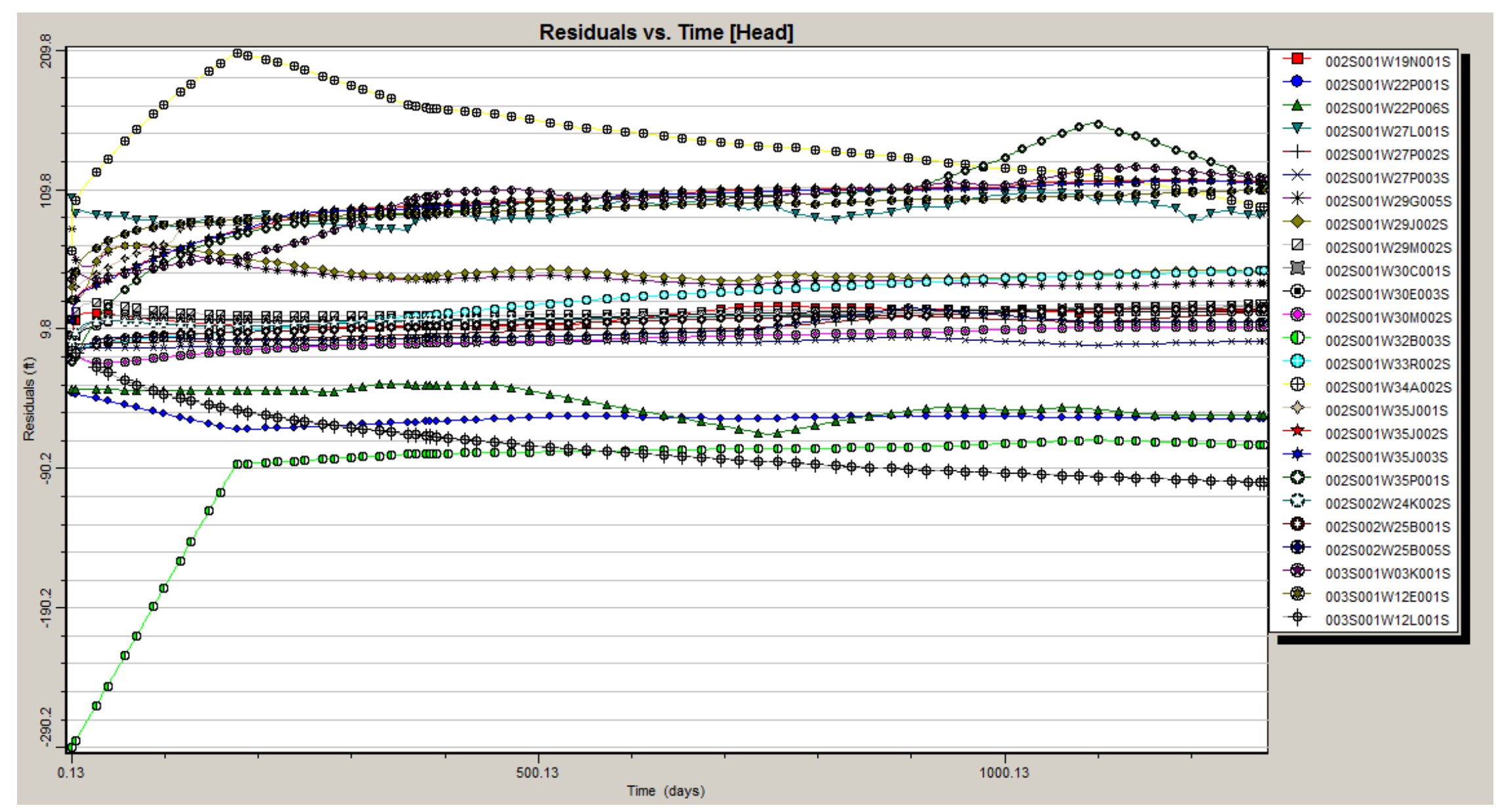

Figure 23: Residuals vs. time, 1278 day model 


\section{Chapter 7: Alternative Scenarios of Future Aquifer Management}

\section{Models of Alternatives}

When using a mathematical model to show the movement of nitrates through an aquifer, one can make some assumptions that help to simplify the modeling process. The primary mechanism for lowering nitrate concentrations within an aquifer is dilution, unless the aquifer has an extremely low concentration of oxygen available for bacteria (Taylor 2003). Thus, the groundwater management and remediation alternatives proposed in this study focus on containing nitrate within specific regions of the Beaumont Basin, diluting the concentration of nitrate within the Beaumont Basin, or combining these strategies.

Before assessing alternatives for groundwater management in the Beaumont Basin, a General Forecast model has been developed to see how the population of Beaumont and Cherry Valley will affect groundwater flow and nitrate transport. This model uses projected population data to determine pumping rates that are needed to meet groundwater demands through 2035 .

A few alternative scenarios have been considered to test how the movement of nitrate within the aquifer will react to changes in the water management infrastructure in the Beaumont Basin. One alternative is to adjust the recharge rate of SWP water to the recharge ponds maintained by the BCVWD. In this scenario, the amount of SWP water delivered to the recharge site would be adjusted so that the smaller volume of water would be allowed to percolate at a given time. In theory, this will create a more gradual groundwater 
mounding effect near the recharge ponds, which may result in a smaller hydraulic gradient to push nitrates out of the Cherry Valley region of the Beaumont Basin.

Another set of alternatives adjusting the pumping rates of existing production wells in and near the Cherry Valley region of the Beaumont Basin, with the goal of pumping nitrate-contaminated groundwater out of the Beaumont Basin to be treated for contaminants. The treated water could then be recharged back into the aquifer through percolation beds or, potentially, added directly to the water supply if cleaned to a sufficient level.

A third set of possible alternatives includes constructing additional artificial recharge ponds to add more mounding to the water table south of the Cherry Valley region, creating a barrier that may hold contaminated groundwater in the Cherry Valley region.

\section{Future Population Considerations}

Since each alternative for the groundwater model will need to take place in the future, changes in population and land use must be taken into account. The BCVWD has provided a draft report of potential changes in population, which cites population changes from the past decade as well as potential future growth based on previous growth rates and economic effects. (Beaumont-Cherry Valley Water District 2011) A historical population of Beaumont is shown below in Table 6. 
Table 6: Historical Population of Beaumont and Cherry Valley...

\begin{tabular}{|r|r|r|r|r|}
\hline & 1980 & 1990 & 2000 & 2010 \\
\hline City of Beaumont & & & & \\
\hline Population & 6818 & 9685 & 11407 & 36837 \\
\hline Households & 2852 & 3718 & 3887 & 12950 \\
\hline People/Household & 2.39 & 2.60 & 2.93 & 2.84 \\
\hline & & & & \\
\hline Cherry Valley & & & & \\
\hline Population & 5012 & 2530 & 5891 & 6279 \\
\hline Households & 2023 & 2530 & 2310 & 2450 \\
\hline People/Household & 2.48 & 2.35 & 2.55 & 2.56 \\
\hline & & & & \\
\hline TOTAL & & & & \\
\hline Population & 11130 & 15630 & 17298 & 43116 \\
\hline Households & 4875 & 6248 & 6197 & 15400 \\
\hline People/Household & 2.43 & 2.50 & 2.79 & 2.80 \\
\hline
\end{tabular}

The following tables are also from the Urban Water Management Plan for BCVWD, which show the differences between the expected population growth as reported by the Southern California Association of Governments (SCAG), prepared by the Western Riverside Council of Governments (WRCOG), and as calculated and reported by the BCVWD (Beaumont-Cherry Valley Water District 2011). The Population estimation conducted by the BCVWD takes into account the recession that began in late 2008 , which has led to a decline in the number of homes being sold and occupied within the Beaumont and Cherry Valley area. For the purposes of this study, the population estimations generated by the BCVWD will be used to evaluate any changing conditions for Beaumont and Cherry Valley (Beaumont-Cherry Valley Water District 2011).

${ }^{2}$ (Beaumont-Cherry Valley Water District 2011) 
Table 7: SCAG/WRCOG Population Estimates (Beaumont-Cherry Valley Water District 2011) ...

\begin{tabular}{|c|c|c|c|c|c|c|c|c|c|c|}
\hline & 1980 & 1990 & 2000 & 2005 & 2010 & 2015 & 2020 & 2025 & 2030 & 2035 \\
\hline \multicolumn{11}{|l|}{ City of Beaumont } \\
\hline Population & 6818 & 9685 & 11407 & 21242 & 33950 & 45029 & 52591 & 63660 & 74686 & 77439 \\
\hline $\begin{array}{c}\text { Population Change Per } \\
\text { Period }\end{array}$ & & & & & 12708 & 11079 & 7562 & 11069 & 11026 & 2753 \\
\hline $\begin{array}{c}\text { Population Change per } \\
\text { Period } \%\end{array}$ & & & & & $60 \%$ & $33 \%$ & $17 \%$ & $21 \%$ & $17 \%$ & $4 \%$ \\
\hline Households & 2852 & 3718 & 3887 & 7071 & 11032 & 15428 & 18888 & 22747 & 26728 & 27745 \\
\hline People/Household & 2.39 & 2.60 & 2.93 & 3.00 & 3.08 & 2.92 & 2.78 & 2.80 & 2.79 & 2.79 \\
\hline \multicolumn{11}{|l|}{ Cherry Valley } \\
\hline Population & 5012 & 5945 & 5891 & 6657 & 8403 & 9818 & 12014 & 13957 & 15640 & 17528 \\
\hline $\begin{array}{c}\text { Population Change Per } \\
\text { Period }\end{array}$ & & & & & 1746 & 1415 & 2196 & 1943 & 1683 & 1888 \\
\hline $\begin{array}{c}\text { Population Change per } \\
\text { Period } \%\end{array}$ & & & & & $26 \%$ & $17 \%$ & $22 \%$ & $16 \%$ & $12 \%$ & $12 \%$ \\
\hline Households & 2023 & 2530 & 2310 & 2583 & 3215 & 3716 & 4552 & 6198 & 5748 & 6388 \\
\hline People/Household & 2.48 & 2.35 & 2.55 & 2.58 & 2.61 & 2.64 & 2.64 & 2.70 & 2.72 & 2.74 \\
\hline \multicolumn{11}{|l|}{ TOTAL } \\
\hline Population & 11130 & 15630 & 17298 & 27899 & 42353 & 54847 & 64605 & 77617 & 90326 & 94967 \\
\hline $\begin{array}{c}\text { Population Change Per } \\
\text { Period }\end{array}$ & & & & & 14454 & 12494 & 9758 & 13012 & 12709 & 4641 \\
\hline $\begin{array}{c}\text { Population Change per } \\
\text { Period } \%\end{array}$ & & & & & $52 \%$ & $29 \%$ & $18 \%$ & $20 \%$ & $16 \%$ & $5 \%$ \\
\hline Households & 4875 & 6248 & 6197 & 9654 & 14247 & 19144 & 23440 & 27915 & 32476 & 34133 \\
\hline People/Household & 2.43 & 2.50 & 2.79 & 2.89 & 2.97 & 2.86 & 2.76 & 2.78 & 2.78 & 2.78 \\
\hline
\end{tabular}

${ }^{3}$ U.S. Census Bureau, 2000 Census of Population and Housing, Population and Housing Unit Counts, PHC-3-6, California, Washington D.C., 2003 for the years 1980, 1990, and 2000. All other data from SCAG/WRCOG. Note that 2010 data does not conform to 2010 census data 
Table 8: 2010 UWMP Population and Household Projections (Beaumont-Cherry Valley Water District 2011)

\begin{tabular}{|c|c|c|c|c|c|c|c|c|c|c|}
\hline & 1980 & 1990 & 2000 & 2005 & 2010 & 2015 & 2020 & 2025 & 2030 & 2035 \\
\hline \multicolumn{11}{|l|}{ City of Beaumont } \\
\hline Population & 6,818 & 9,685 & $\begin{array}{c}11,40 \\
7\end{array}$ & $\begin{array}{c}24,90 \\
9\end{array}$ & $\begin{array}{c}36,83 \\
7\end{array}$ & $\begin{array}{c}39,78 \\
4\end{array}$ & $\begin{array}{c}43,76 \\
2\end{array}$ & $\begin{array}{c}49,01 \\
4\end{array}$ & $\begin{array}{c}54,89 \\
5\end{array}$ & $\begin{array}{c}61,48 \\
3\end{array}$ \\
\hline $\begin{array}{c}\text { Population Change } \\
\text { per Period }\end{array}$ & & 2867 & 1722 & 13502 & 11928 & 2947 & 3978 & 5251 & 5882 & 6587 \\
\hline $\begin{array}{l}\text { Population Change } \\
\text { per Period \% }\end{array}$ & & $42 \%$ & $18 \%$ & $118 \%$ & $48 \%$ & $8 \%$ & $10 \%$ & $12 \%$ & $12 \%$ & $12 \%$ \\
\hline Households & 2,852 & 3,718 & 3,887 & 8675 & 12950 & 14058 & 15629 & 17505 & 19606 & 21958 \\
\hline People/Household & 2.39 & 2.60 & 2.93 & 2.87 & 2.84 & 2.83 & 2.80 & 2.80 & 2.80 & 2.80 \\
\hline \multicolumn{11}{|l|}{ Cherry Valley } \\
\hline Population & 5,012 & 5,945 & 5,891 & 6,085 & 6,279 & 6,530 & 7,053 & 7,758 & 8,689 & 9,992 \\
\hline $\begin{array}{c}\text { Population Change } \\
\text { per Period }\end{array}$ & & 933 & 54 & 194 & 194 & 251 & 522 & 705 & 931 & 1303 \\
\hline $\begin{array}{c}\text { Population Change } \\
\text { per Period \% }\end{array}$ & & $19 \%$ & $1 \%$ & $3 \%$ & $3 \%$ & $4 \%$ & $8 \%$ & $10 \%$ & $12 \%$ & $15 \%$ \\
\hline Households & 2,023 & 2,530 & 2,310 & 2385 & 2450 & 2512 & 2661 & 2873 & 3194 & 3647 \\
\hline People/Household & 2.48 & 2.35 & 2.55 & 2.55 & 2.56 & 2.60 & 2.65 & 2.70 & 2.72 & 2.74 \\
\hline \multicolumn{11}{|l|}{ TOTAL } \\
\hline Population & $\begin{array}{c}11,13 \\
0\end{array}$ & $\begin{array}{c}15,63 \\
0\end{array}$ & $\begin{array}{c}17,29 \\
8\end{array}$ & $\begin{array}{c}30,99 \\
4\end{array}$ & $\begin{array}{c}43,11 \\
6\end{array}$ & $\begin{array}{c}46,31 \\
4\end{array}$ & $\begin{array}{c}50,81 \\
5\end{array}$ & $\begin{array}{c}56,77 \\
2\end{array}$ & $\begin{array}{c}63,58 \\
4\end{array}$ & $\begin{array}{c}71,47 \\
5\end{array}$ \\
\hline $\begin{array}{c}\text { Population Change } \\
\text { per Period }\end{array}$ & & 3800 & 1668 & 13696 & 12122 & 3198 & 4501 & 5957 & 6813 & 7891 \\
\hline $\begin{array}{l}\text { Population Change } \\
\text { per Period \% }\end{array}$ & & $32 \%$ & $11 \%$ & $79 \%$ & $39 \%$ & $7 \%$ & $10 \%$ & $12 \%$ & $12 \%$ & $12 \%$ \\
\hline Households & 4,875 & 6,248 & 6,197 & 11060 & 15400 & 16570 & 18291 & 20378 & 22800 & 25605 \\
\hline $\begin{array}{c}\text { People/Househol } \\
\text { d }\end{array}$ & 2.43 & 2.50 & 2.79 & 2.80 & 2.80 & 2.80 & 2.78 & 2.79 & 2.79 & 2.79 \\
\hline
\end{tabular}

\section{Future Groundwater Pumping Considerations}

With this change in populations, it is anticipated that more water will be pumped from the Beaumont Basin by the BCVWD. To account for this pumping, some correlations were made between the amount of water pumped per year, or the average flow rate, to the population of Beaumont and Cherry Valley. These correlations allowed for the development of a projected amount of pumping that corresponds to the projected population growth from the Urban Water Management Plan Report (Beaumont-Cherry Valley Water District 2011).

Figure 24 shows the volumes of pumping, in gallons, over time within the Beaumont Basin by BCVWD wells and wells owned by major pumping entities within the Beaumont Basin. The graph shows a noticeable increase in pumping 
from all wells that begins in the late 1990 s and continues to increase rapidly between 2000 and 2010, which corresponds with the growth in population in Beaumont and Cherry Valley.

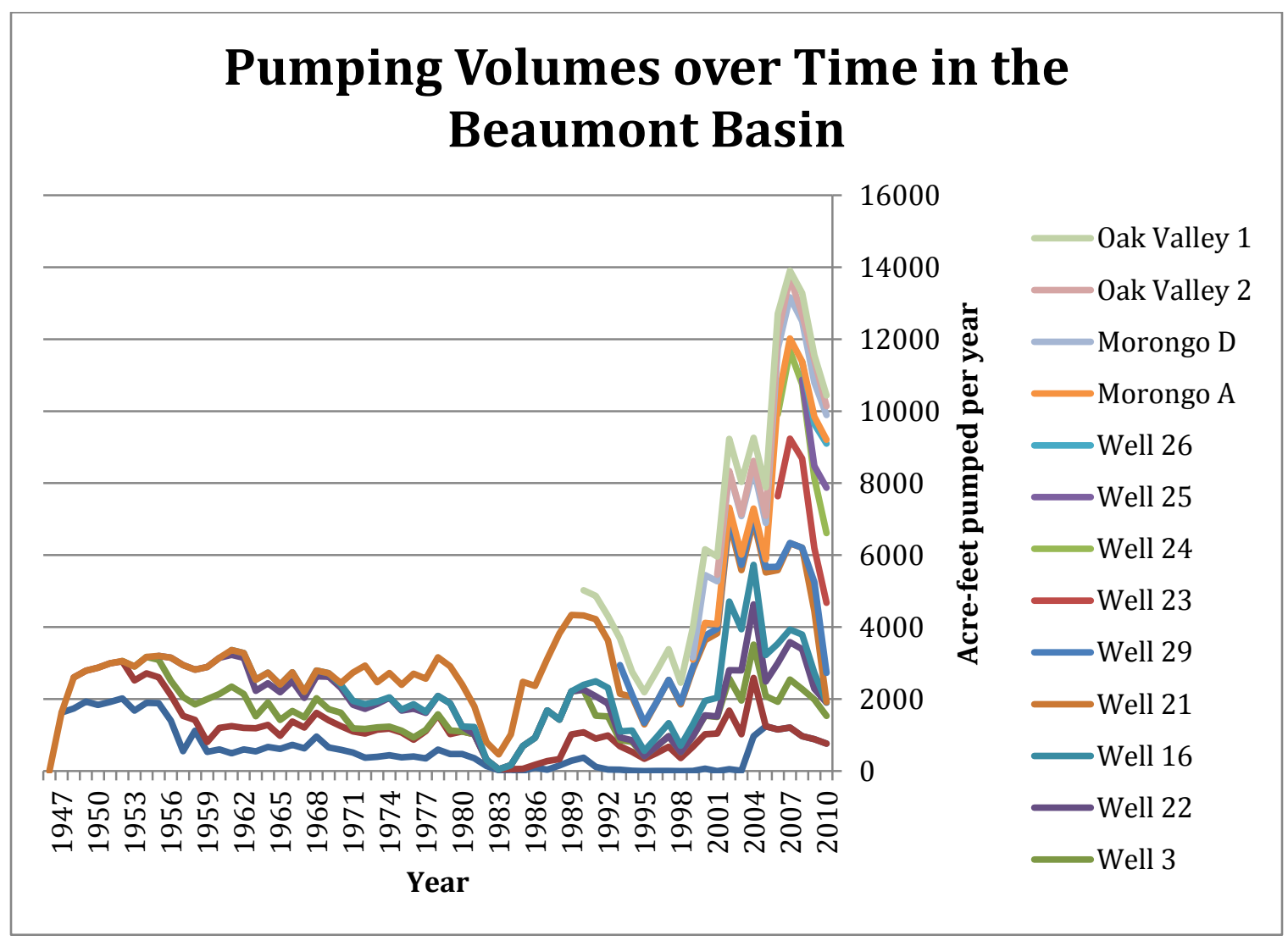

Figure 24: Pumping Volumes over Time in the Beaumont Basin

To better illustrate the positive correlation between pumping rates and population increase, the following chart graphs the total population of Beaumont and Cherry Valley from 1980 to 2010 against the total average GPM pumped within the Beaumont Basin for the same years. Trend lines for the plotted data show that the total average pumping rates in the Beaumont Basin by wells maintained by the BCVWD can be assumed to be approximately equal to

$$
y=0.1244 x+386.12
$$

Where $y$ is the total average GPM pumped from the Beaumont Basin for a given 
year and $x$ is the total population of Beaumont and Cherry Valley for that same given year.

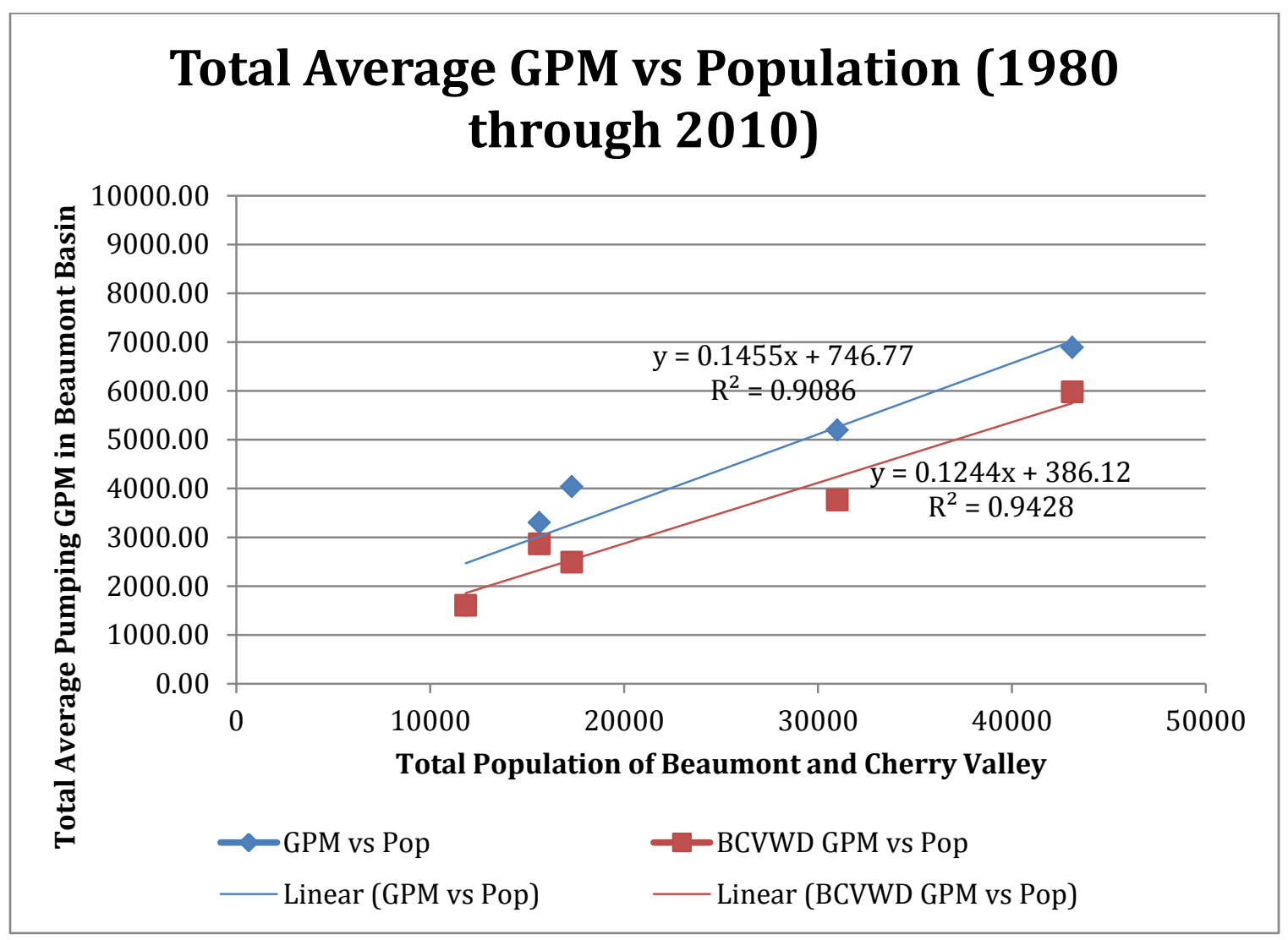

Figure 25: Total Average GPM vs. Population (1980 through 2010)

Using the relationship defined in Figure 25, an approximate total average pumping rate can be assumed for BCVWD wells in the Beaumont basin, as shown in Figure 26. As seen in Figure 26, the average total GPM takes a small dip in the rate of increase between 2010 and 2015, which is consistent with the population growth slump due to economic recession as projected in the Urban Water Management Plan (Beaumont-Cherry Valley Water District 2011) 


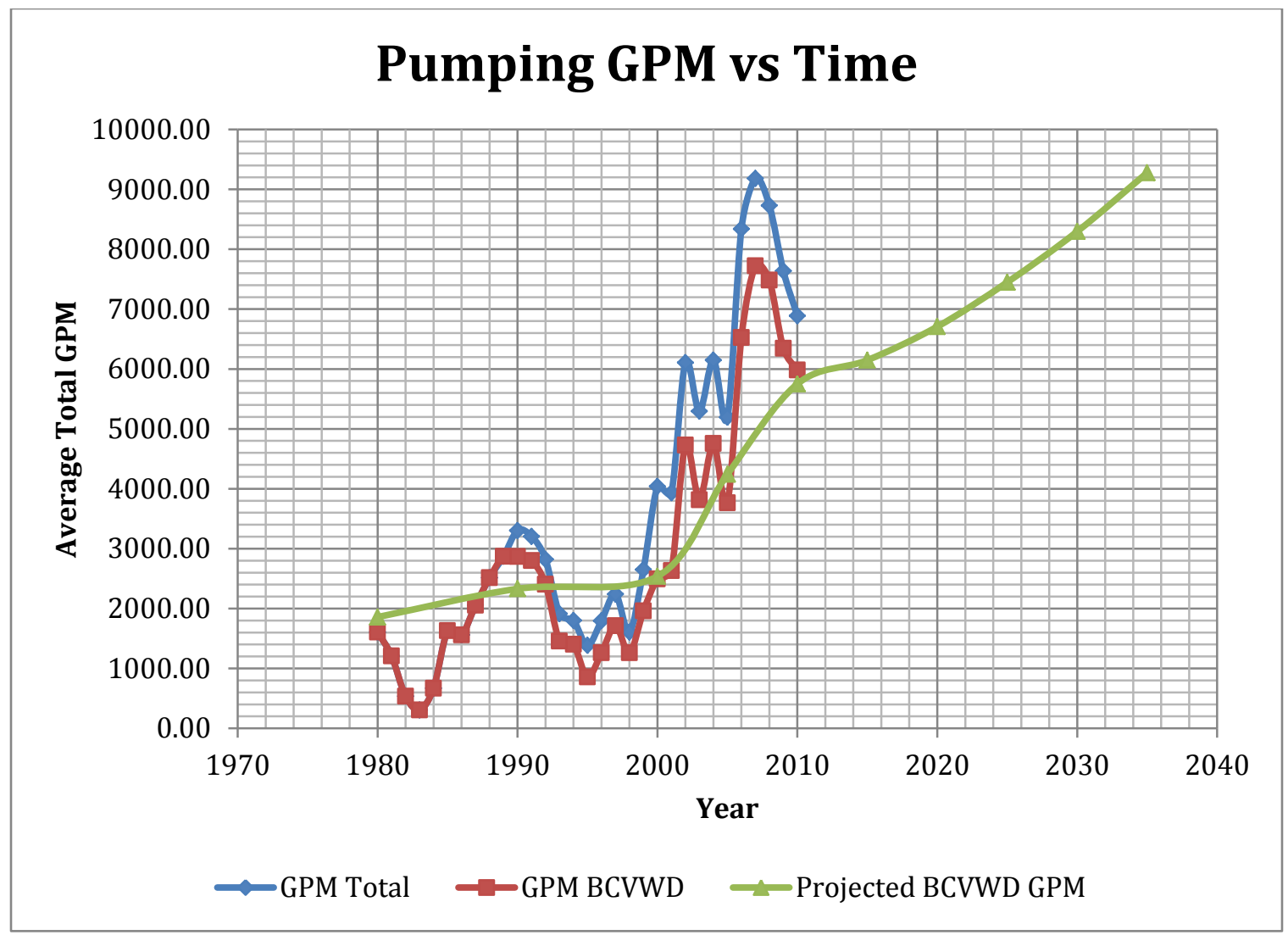

Figure 26: Projected vs. historical pumping rates in the Beaumont Basin

Projected average pumping rates were then assigned for each BCVWD production well to meet the projected demand due to population increase. The pumping rates were assigned based on the total capacity of the pumps (Beaumont-Cherry Valley Water District 1995) and on the percentage of the pumping capacity generated by each well. The total capacity of each well is taken as $75 \%$ of the nominal capacity, since BCVWD often avoids running wells during peak electricity hours to avoid higher energy costs. (Reichenberger 2012) Peak electricity hours, as stated by Southern California Edison, are from noon to 6:00 PM, (Southern California Edison 2010) so the limit for daily operation is 18 hours or $75 \%$ of a day. An example of the calculation for an effective pumping rate would be: if a well had a nominal pumping capacity of $1000 \mathrm{gpm}$, and the 
average flow rate from the well was recorded as $500 \mathrm{gpm}$, then the pump is operating at $66 \%$ capacity, since the $100 \%$ capacity would be $750 \mathrm{gpm}$.

Projected pumping rates were assigned to BCVWD production wells using the scheme outline in Table 9. For years 2015 through 2035, each well was assigned a progressive pumping capacity based on the pumping rate used in 2010. In wells 16 and 21 , the pumping rate was not increased due to the amount of nitrate near those well locations. Since the goal of the alternative modeling scenarios is to test for alternative methods in groundwater infrastructure management to adjust the flow of contaminants through the aquifer, it is appropriate to adjust wells in areas where the concentration of nitrates is the highest, as increasing pumping in these wells may increase the amount of nitrate delivered through the pumping infrastructure. 
Table 9: Pumping rates for BCVWD production wells in projected models

\begin{tabular}{|c|c|c|c|c|c|c|}
\hline & \multicolumn{2}{|c|}{2010} & \multicolumn{2}{|c|}{2015} & \multicolumn{2}{|c|}{2020} \\
\hline Well & GPM & $\begin{array}{c}\% \\
\text { Capacity }\end{array}$ & GPM & $\begin{array}{c}\% \\
\text { Capacity }\end{array}$ & GPM & $\begin{array}{c}\% \\
\text { Capacity }\end{array}$ \\
\hline 1 & 473.63 & 63.15 & 487.5 & 65 & 525 & 70 \\
\hline 2 & 0.00 & 0 & 675 & 50 & 742.5 & 55 \\
\hline 3 & 476.69 & 28.89 & 495 & 30 & 577.5 & 35 \\
\hline 16 & 6.24 & 0.64 & 4.875 & 0.5 & 4.875 & 0.5 \\
\hline 21 & 5.61 & 0.34 & 8.25 & 0.5 & 8.25 & 0.5 \\
\hline 22 & 228.11 & 17.38 & 262.5 & 20 & 328.125 & 25 \\
\hline 23 & 1206.94 & 64.37 & 1218.75 & 65 & 1218.75 & 65 \\
\hline 24 & 1201.31 & 64.07 & 1218.75 & 65 & 1218.75 & 65 \\
\hline 25 & 779.85 & 69.32 & 787.5 & 70 & 787.5 & 70 \\
\hline 26 & 762.51 & 36.31 & 840 & 40 & 945 & 45 \\
\hline \multirow[t]{2}{*}{29} & 550.28 & 33.35 & 495 & 30 & 495 & 30 \\
\hline & \multicolumn{2}{|c|}{2025} & \multicolumn{2}{|c|}{2030} & \multicolumn{2}{|c|}{2035} \\
\hline Well & GPM & $\begin{array}{c}\% \\
\text { Capacity }\end{array}$ & GPM & $\begin{array}{c}\% \\
\text { Capacity }\end{array}$ & GPM & $\begin{array}{c}\% \\
\text { Capacity }\end{array}$ \\
\hline 1 & 525 & 70 & 562.5 & 75 & 600 & 80 \\
\hline 2 & 877.5 & 65 & 945 & 70 & 1080 & 80 \\
\hline 3 & 742.5 & 45 & 825 & 50 & 907.5 & 55 \\
\hline 16 & 4.875 & 0.5 & 4.875 & 0.5 & 4.875 & 0.5 \\
\hline 21 & 8.25 & 0.5 & 8.25 & 0.5 & 8.25 & 0.5 \\
\hline 22 & 393.75 & 30 & 459.375 & 35 & 590.625 & 45 \\
\hline 23 & 1218.75 & 65 & 1218.75 & 65 & 1218.75 & 65 \\
\hline 24 & 1312.5 & 70 & 1406.25 & 75 & 1500 & 80 \\
\hline 25 & 843.75 & 75 & 900 & 80 & 956.25 & 85 \\
\hline 26 & 1050 & 50 & 1365 & 65 & 1680 & 80 \\
\hline 29 & 577.5 & 35 & 660 & 40 & 742.5 & 45 \\
\hline
\end{tabular}

Using the values show in Table 9, it can be seen that for the population growth prediction outlined by the Urban Water Management Plan draft report, many of the existing wells would need to operate during nearly all off-peak hours to meet the demand of Beaumont and Cherry Valley. New wells may need to be developed within the Beaumont Basin to ensure that enough water can be withdrawn from the aquifer to meet water needs. 
To account for changes in concentrations of nitrate throughout the Beaumont Basin in projected scenarios, a common initial concentration value needed to be established for the extent of the model. While water quality data from BCVWD does provide much data for the production wells in the Beaumont Basin, some of the wells in the Cherry Valley region of the Beaumont Basin have nitrate concentration data that vary dramatically from year to year. Upon closer inspection, the nitrate concentrations in these wells appear to spike shortly after a period of heavy rainfall when compared to precipitation data provided by the Riverside County Flood Control District (Riverside County Flood Control Department 2011). Since the production wells in the Cherry Valley region that have the greatest nitrate concentrations are located along drainage paths for seasonal rainfall, it is possible that the increase rainfall has contributed to the recharge of nitrates from surface waters. Since the data provided for the nitrate concentrations of these wells are typically taken once a year, it is difficult to place any confident relationship between the spike in nitrate concentrations and the increased rainfall. The initial concentrations used in the projected scenarios use the average concentration for each major BCVWD production well from March 2, 2005, to December 9, 2010. These average values, assigned to each major production well, can be seen in Table 10. 
Table 10: Initial Nitrate Concentrations for Projected Scenarios

\begin{tabular}{|c|c|}
\hline $\begin{array}{c}\text { BCVWD Production } \\
\text { Well }\end{array}$ & $\begin{array}{c}\text { Nitrate Concentration } \\
\text { (mg/L) }\end{array}$ \\
\hline 1 & 3.91 \\
\hline 2 & 3.00 \\
\hline 3 & 4.61 \\
\hline 16 & 23.50 \\
\hline 21 & 19.57 \\
\hline 22 & 3.31 \\
\hline 23 & 5.83 \\
\hline 24 & 4.05 \\
\hline 25 & 4.35 \\
\hline 26 & 4.20 \\
\hline 29 & 6.20 \\
\hline
\end{tabular}

\section{Future Recharge and Recharge Concentration Considerations}

Beyond the initial nitrate concentrations for the Beaumont Basin, projected models also attempt to address any changes in the recharge concentrations from future growth in the Cherry Valley region. In Cherry Valley, it is now policy that no new septic systems will be allowed for future development unless these systems are capable of removing at least $50 \%$ of the nitrate from septic system effluent (University of California, Riverside 2012). Since it is possible for clustered decentralized treatment systems to process wastewater from 200 homes or more (U.S. Environmental Protection Agency 2009), a scenario where a housing development containing 10 homes per model cell has been added to projected models, which contributes a nitrate concentration of $25 \mathrm{mg} / \mathrm{L}$ (half of the assumed $50 \mathrm{mg} / \mathrm{L}$ contributed from older systems in the Cherry Valley region, as stated in Recharge on page 22).

These homes were placed toward the western end of the Beaumont Basin, where there are many flat fields that could provide a simple landscape for 
residential development. Since the hills of Cherry Valley contain some varying topography and are more densely populated, it was assumed that any major housing developments would be constructed on this western end of the Beaumont Basin. There are currently many homes in the western end of the Beaumont Basin that are within Beaumont city limits, and thus are connected to the Beaumont sewer systems.

The homes added for this future housing development were implemented in projected models in 5 phases, corresponding to years 2010-2015, 2015-2020, 2020-2025, 2025-2030, and 2030-2035. Each phase is placed so that a growth in the number of homes is proportional to the growth in population within Cherry Valley, as projected by the UWMP draft report (See Table 8: 2010 UWMP Population and Household Projections on page 70). Since it is assumed that there are 10 homes per model cell, and that each home has an average of 2.4 residents, a projected housing development was modeled using the scheme outlined in Table 11. The recharge rates provided are scheduled into each projected model so that each additional phase is accounted for in sequence. A model view of recharge that accounts for this new housing development on septic tank systems is shown in Figure 27. 
Table 11: Recharge Rates Assigned to Potential Development in Cherry Valley, ft/day

\begin{tabular}{|l|r|r|c|c|c|c|c|}
\hline \multirow{2}{*}{ Year } & \multicolumn{6}{|c|}{ Model Day } & \multicolumn{5}{|c|}{ Phase, Total Additional Model Cells } \\
\cline { 2 - 9 } & Start & End & $\mathbf{1 , 1 1}$ & $\mathbf{2 , 2 2}$ & $\mathbf{3 , 2 9}$ & $\mathbf{4 , 3 9}$ & $\mathbf{5 , 5 4}$ \\
\hline $\mathbf{2 0 1 0}$ & & & & & & & \\
\hline $\mathbf{2 0 1 1}$ & 240 & 605 & 0.000927 & 0 & 0 & 0 & 0 \\
\hline $\mathbf{2 0 1 2}$ & 605 & 971 & 0.001544 & 0 & 0 & 0 & 0 \\
\hline $\mathbf{2 0 1 3}$ & 971 & 1336 & 0.002162 & 0 & 0 & 0 & 0 \\
\hline $\mathbf{2 0 1 4}$ & 1336 & 1701 & 0.002780 & 0 & 0 & 0 & 0 \\
\hline $\mathbf{2 0 1 5}$ & 1701 & 2066 & 0.003398 & 0 & 0 & 0 & 0 \\
\hline $\mathbf{2 0 1 6}$ & 2066 & 2432 & 0.003398 & 0.000772 & 0 & 0 & 0 \\
\hline $\mathbf{2 0 1 7}$ & 2432 & 2797 & 0.003398 & 0.001390 & 0 & 0 & 0 \\
\hline $\mathbf{2 0 1 8}$ & 2797 & 3162 & 0.003398 & 0.002162 & 0 & 0 & 0 \\
\hline $\mathbf{2 0 1 9}$ & 3162 & 3527 & 0.003398 & 0.002780 & 0 & 0 & 0 \\
\hline $\mathbf{2 0 2 0}$ & 3527 & 3893 & 0.003398 & 0.003398 & 0 & 0 & 0 \\
\hline $\mathbf{2 0 2 1}$ & 3893 & 4258 & 0.003398 & 0.003398 & 0.000703 & 0 & 0 \\
\hline $\mathbf{2 0 2 2}$ & 4258 & 4623 & 0.003398 & 0.003398 & 0.001406 & 0 & 0 \\
\hline $\mathbf{2 0 2 3}$ & 4623 & 4988 & 0.003398 & 0.003398 & 0.002109 & 0 & 0 \\
\hline $\mathbf{2 0 2 4}$ & 4988 & 5354 & 0.003398 & 0.003398 & 0.002812 & 0 & 0 \\
\hline $\mathbf{2 0 2 5}$ & 5354 & 5719 & 0.003398 & 0.003398 & 0.003398 & 0 & 0 \\
\hline $\mathbf{2 0 2 6}$ & 5719 & 6084 & 0.003398 & 0.003398 & 0.003398 & 0.000697 & 0 \\
\hline $\mathbf{2 0 2 7}$ & 6084 & 6449 & 0.003398 & 0.003398 & 0.003398 & 0.001394 & 0 \\
\hline $\mathbf{2 0 2 8}$ & 6449 & 6815 & 0.003398 & 0.003398 & 0.003398 & 0.002091 & 0 \\
\hline $\mathbf{2 0 2 9}$ & 6815 & 7180 & 0.003398 & 0.003398 & 0.003398 & 0.002788 & 0 \\
\hline $\mathbf{2 0 3 0}$ & 7180 & 7545 & 0.003398 & 0.003398 & 0.003398 & 0.003398 & 0 \\
\hline $\mathbf{2 0 3 1}$ & 7545 & 7910 & 0.003398 & 0.003398 & 0.003398 & 0.003398 & 0.000692 \\
\hline $\mathbf{2 0 3 2}$ & 7910 & 8276 & 0.003398 & 0.003398 & 0.003398 & 0.003398 & 0.001384 \\
\hline $\mathbf{2 0 3 3}$ & 8276 & 8641 & 0.003398 & 0.003398 & 0.003398 & 0.003398 & 0.002076 \\
\hline $\mathbf{2 0 3 4}$ & 8641 & 9006 & 0.003398 & 0.003398 & 0.003398 & 0.003398 & 0.002769 \\
\hline $\mathbf{2 0 3 5}$ & 9006 & 9371 & 0.003398 & 0.003398 & 0.003398 & 0.003398 & 0.003398 \\
\hline
\end{tabular}




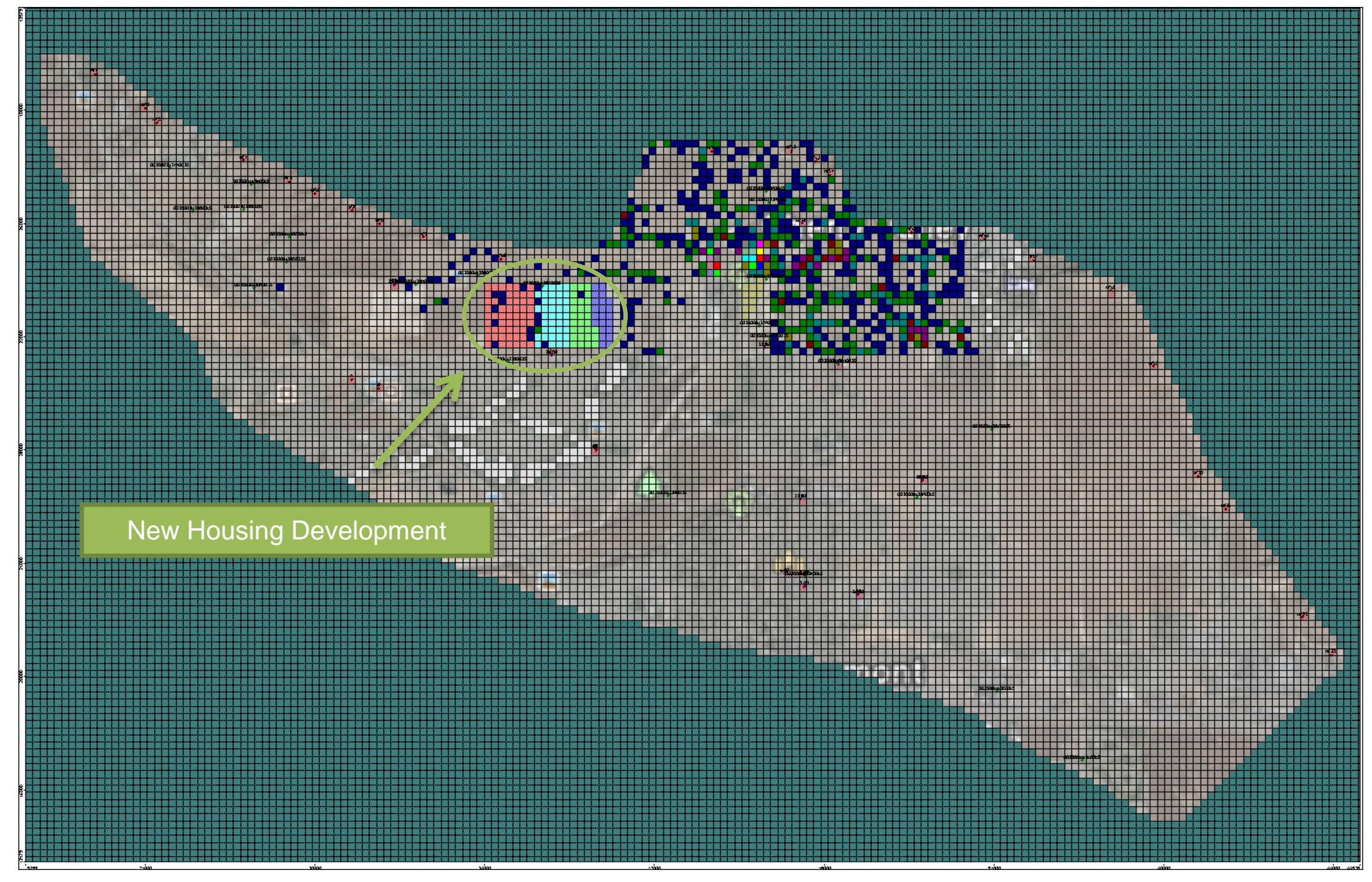

Figure 27: Future Recharge, with housing developments and golf courses 


\section{Alternative Scenarios}

A few different scenarios have been devised to test the performance and response of the aquifer during a model run from 2010 to 2035 . These scenarios include increasing the average rate of recharge applied at the Noble Creek Recharge Basins, decreasing the average rate of recharge applied at the Noble Creek Recharge Basins, and adjusting the production rate of two wells within Cherry Valley, where nitrate concentrations are typically the highest, at peak capacity. A summary of all combinations of variables and alternatives considered in this study are shown in Table 12.

Table 12: Summary of Variables for Recharge and Well Pumping Rates

\begin{tabular}{|c|c|c|c|c|}
\hline \multirow{2}{*}{$\begin{array}{c}\text { Recharge } \\
\text { Rate } \\
\text { (ft/day) }\end{array}$} & \multicolumn{4}{|c|}{ Wells with dramatically increased pumping rates } \\
\cline { 2 - 5 } & $\begin{array}{c}\mathbf{1 6} \\
\text { (975 GPM) }\end{array}$ & $\begin{array}{c}\text { 21 } \\
\text { (1650 GPM) }\end{array}$ & $\begin{array}{c}\mathbf{1 6 ~ \& ~ 2 1} \\
\text { (2625 GPM) }\end{array}$ & None \\
\hline $\mathbf{0 . 6 0}$ & Alternative 8 & Alternative 7 & Alternative 6 & Alternative 1 \\
\hline $\mathbf{0 . 7 5}$ & Alternative 3 & Alternative 4 & Alternative 5 & General Forecast \\
\hline 1.00 & - & - & - & Alternative 2 \\
\hline
\end{tabular}

When looking at the average recharge deliveries added to the Noble Creek Recharge Ponds, it appears that the average delivery of water to the recharge basin is about $0.75 \mathrm{ft} / \mathrm{d}$. Assuming that all of the water applied to the recharge basins infiltrates into the basin, $0.75 \mathrm{ft} /$ day is assumed to be the future value for applied artificial recharge. In Alternatives 1 and 2 , the recharge rate applied to the Noble Creek Recharge Ponds is changed to $0.60 \mathrm{ft} /$ day and 1.00 $\mathrm{ft} /$ day, respectively.

Alternatives 3,4 , and 5 take into account a scenario where excessive pumping takes place in wells that have exhibited the greatest average nitrate 
concentrations from 2005 to 2010 . Since the main mechanism for removing nitrate on a large scale is dilution (Taylor 2003), these alternatives offer scenarios where nitrate is guided out of the aquifer through heavy pumping, resulting in a lowered nitrate concentration near the adjusted wells. Upon viewing some of the outcomes of Alternatives 3, 4, and 5, Alternatives 6, 7, and 8 were added to the study to assess the effects of increased pumping in addition to reduced artificial recharge within the Beaumont Basin.

For Alternatives 3-8, water may be treated using ion exchange or reverse osmosis treatment to reduce the amount of nitrate within the extracted groundwater. Once treated, this groundwater could then be added to the recharge basins and returned to the Beaumont Basin as artificial recharge. Note that none of the alternatives presented in this study account for any additional recharge due to nitrate treatment. This study focuses on the effects of extracting groundwater with elevated nitrate concentrations, and does not simulate any returns of the extracted water through artificial recharge.

Some additional alternatives include potential for installing artificial recharge ponds in other locations within the study area. Since the Noble Creek Recharge Ponds act as a barrier to flow of nitrates from the Cherry Valley area, constructing additional sites for large volumes of artificial recharge may contribute a similar effect to other areas of the Beaumont Basin. Figure 28 and Figure 29 below show potential locations for additional artificial recharge; the pink regions in each figure represent the additional recharge sites. These sites are currently open fields, which will likely be developed at some point during the 
forecasted period from 2010 to 2035 . Since these additional recharge ponds have the same area as the Noble Creek Recharge Ponds (approx. 760,000 sq. $\mathrm{ft}$. ), the forecasted artificial recharge value of $0.75 \mathrm{ft} /$ day for the Noble Creek Recharge Ponds has been partially distributed to the additional recharge ponds. In the first recharge scenario, the Noble Creek ponds have a recharge rate of 0.6 $\mathrm{ft} /$ day and the additional ponds have a recharge rate of $0.15 \mathrm{ft} /$ day. For the second recharge scenario, the Noble Creek ponds are reduced to $0.50 \mathrm{ft} / \mathrm{day}$ of artificial recharge and the additional ponds account for the remaining recharge rate of $0.25 \mathrm{ft} /$ day.

These additional recharge ponds have been placed in these locations because they are currently free of any extensive development. It is likely that there are plans for future housing in these areas, though little or no construction has taken place in these areas. Additionally, there are no observation wells to help account for recharge potential in these areas. The hydraulic properties of the soil in these additional recharge ponds are simply those assigned during the model calibration process, and have not been modified. 


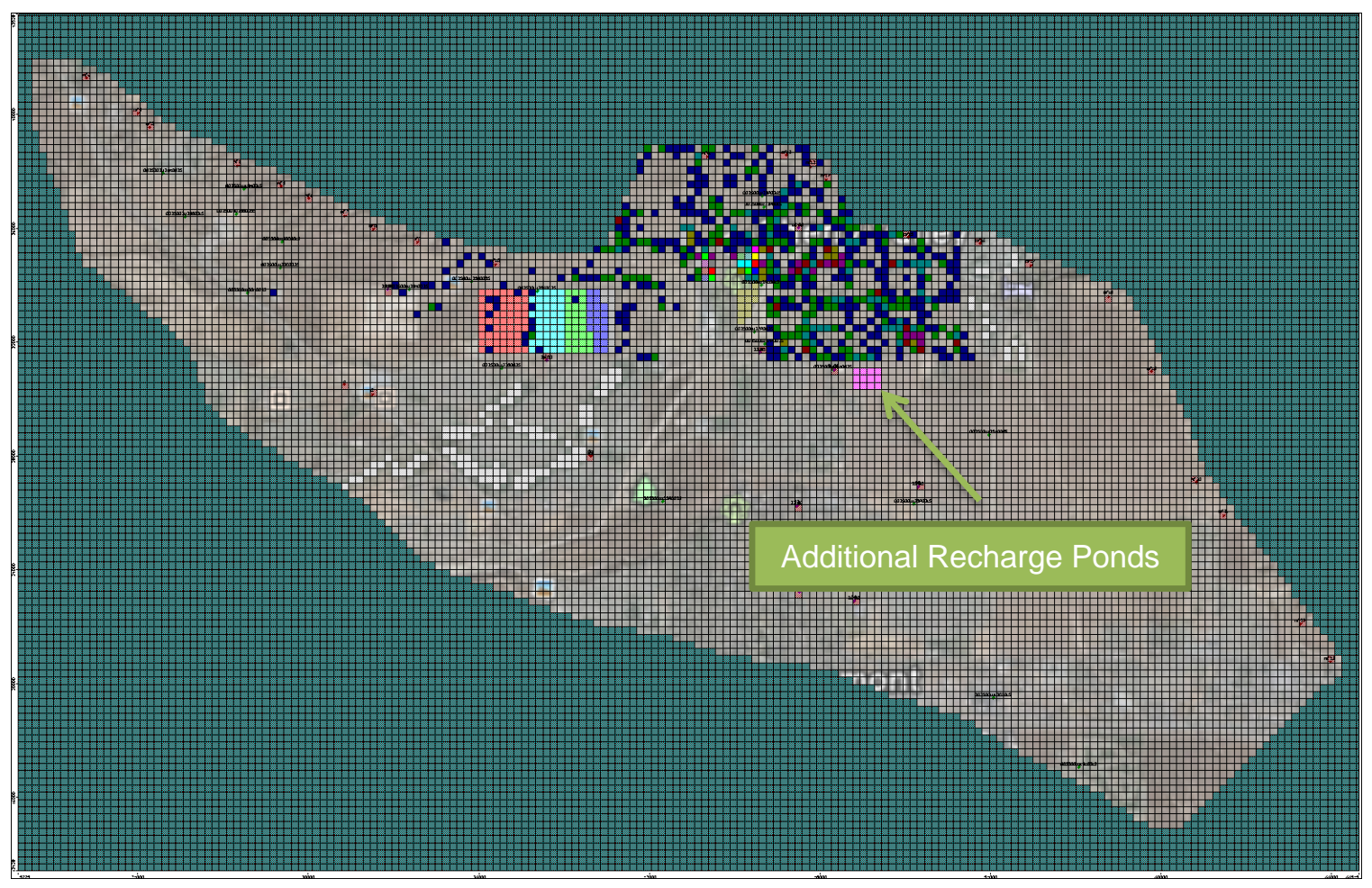

Figure 28: Additional Recharge Alternative 1

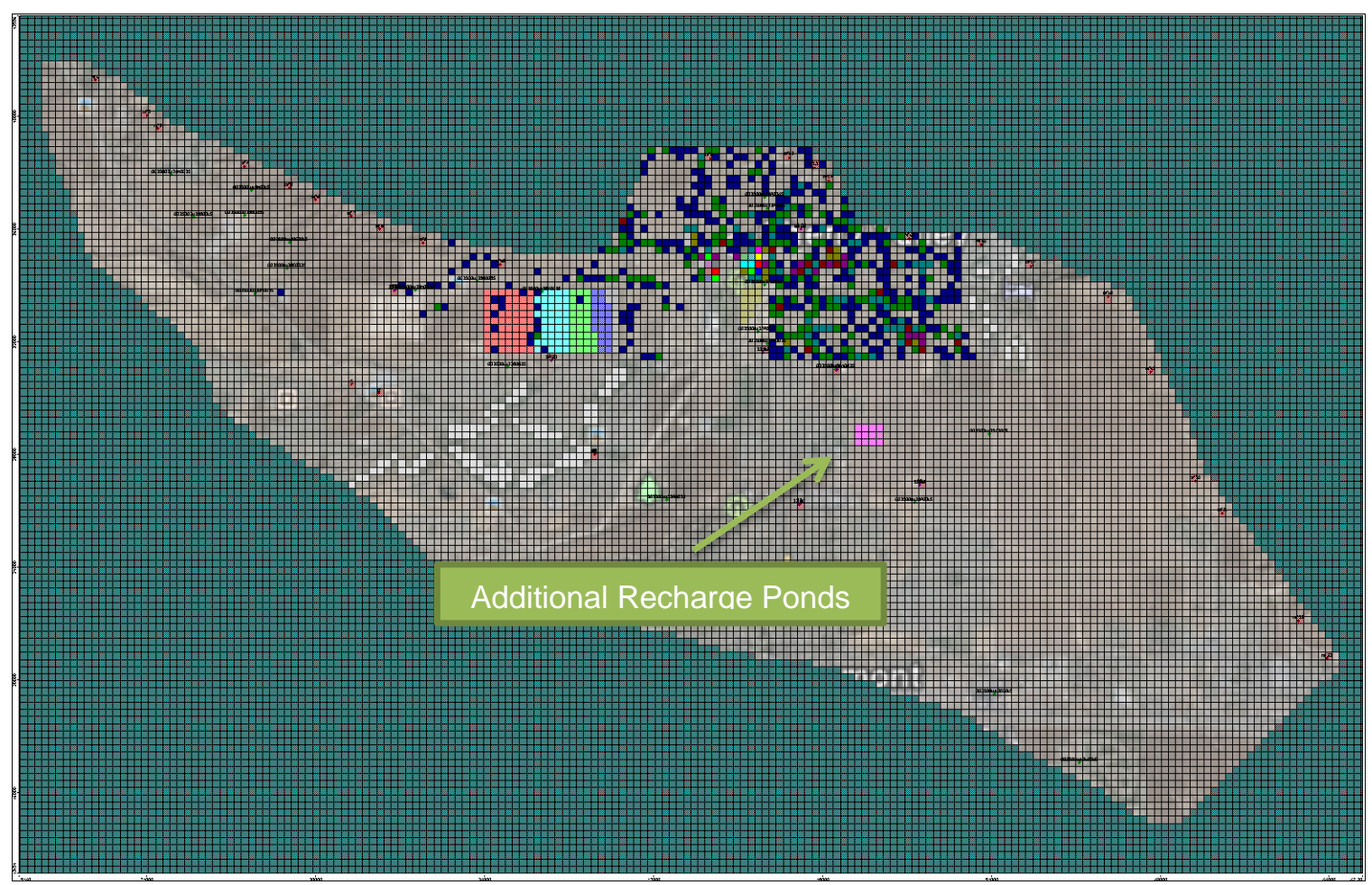

Figure 29: Additional Recharge Alternative 2 
Lastly, to check the effective nitrate loading from septic tanks in the study area, an additional model with an initial nitrate concentrate of $4 \mathrm{mg} / \mathrm{L}$ was created for the Beaumont Basin. By assigning a low initial concentration to the entire model area, it should be easier to see the effects of nitrate loading from septic systems in the Cherry Valley region and any nitrate contributions from mountain front recharge. 


\section{Chapter 8: Results and Discussion}

After running several alternative scenarios for the model region, it became clear that it may be possible to reduce the concentration of nitrate within the Beaumont Basin by adjusting the rate of artificial recharge and strategically pumping wells near areas with high concentrations of nitrate.

With the calibrated conductivity and storage parameters in this model, implementing artificial recharge allows for a zone of very low nitrate concentrations to form near the Noble Creek Recharge Ponds. Assuming that the SWP deliveries to the artificial recharge ponds has a negligible contribution to any nitrate concentrations within the Beaumont Basin, the artificial recharge ponds contribute to diluting the nitrate concentrations within the Beaumont Basin along the Cherry Valley Fault, where the artificial recharge ponds are located.

The increase in population from 2010 to 2035 creates a larger demand for groundwater pumping to meet water needs. Since many of the wells within the Beaumont Basin appear to have a pumping capacity that would accommodate this projected increase in population, pumping from these wells, in effect, draws groundwater with higher concentrations of nitrate from the Cherry Valley region further south into the Beaumont Basin. While none of the modeled areas of the Beaumont Basin exhibit nitrate concentrations that violate the $45 \mathrm{mg} / \mathrm{L} \mathrm{MCL}$ for nitrate within the most active model layer (Layer 4), the model does show that if pumping is limited in the Cherry Valley region, it is possible to draw groundwater with higher nitrate concentrations toward major production wells in the southern portion of the Beaumont Basin, thus increasing the concentration of nitrate 
extracted from these wells.

A general forecast of the study area, where the pumping rates shown in Table 9 are used for the production wells in the model, shows that over time, some of the pockets of higher nitrate concentration located to the south of the Cherry Valley region are drawn toward major production wells in the southern regions of the Beaumont Basin. Figure 30 through Figure 35 show the changing values of nitrate concentration within the Beaumont Basin from 2010 to 2035 . These figures show nitrate concentrations within active, wet cells within the model, so the area of white cells on the eastern side of the model indicate that those cells are not saturated within Layer 4 of the groundwater model. The faults used in the groundwater model are also shown in these figures to show how the faults can have an effect on the movement of nitrate throughout the Beaumont Basin. 


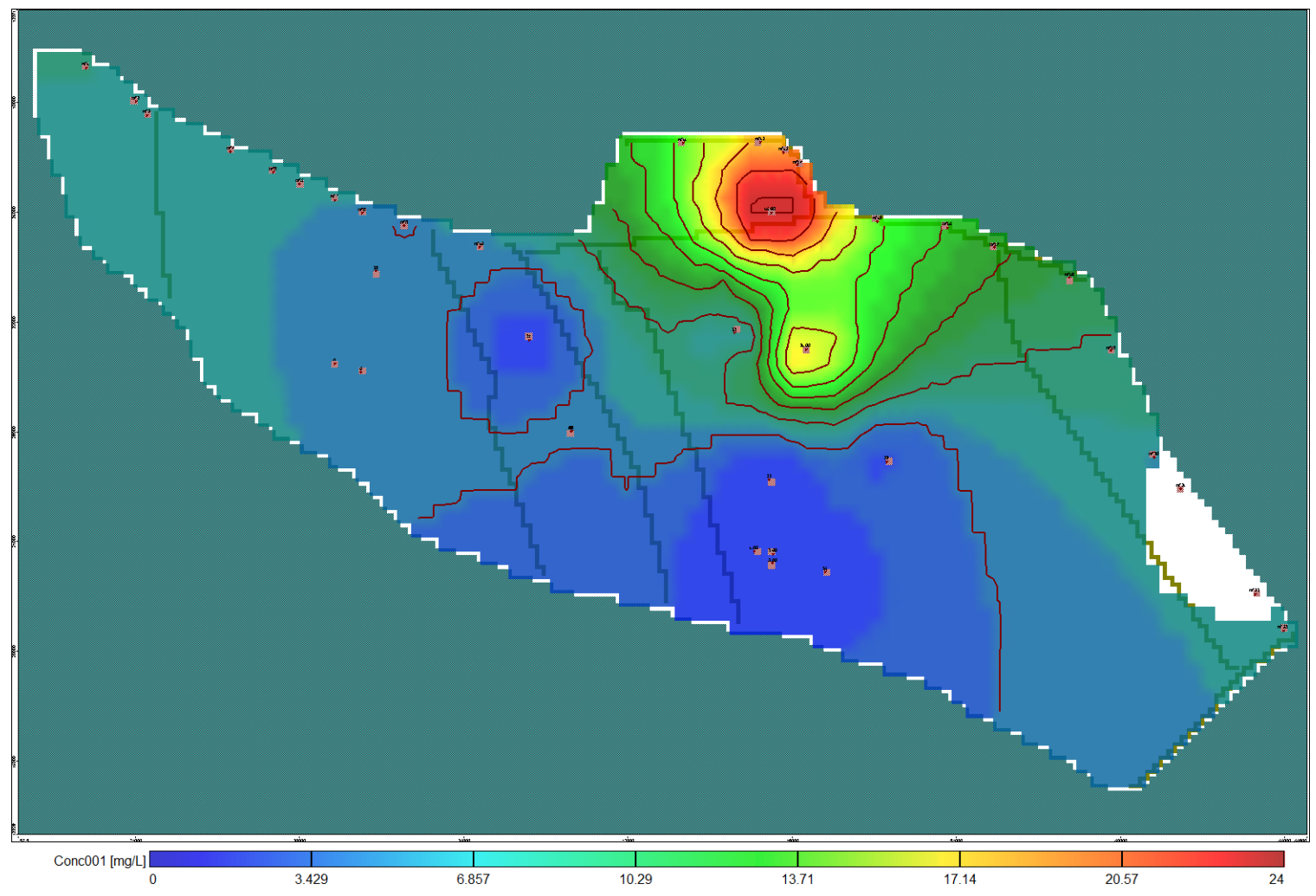

Figure 30: Nitrate (mg/L), General Forecast, Day 26/May 31, 2010

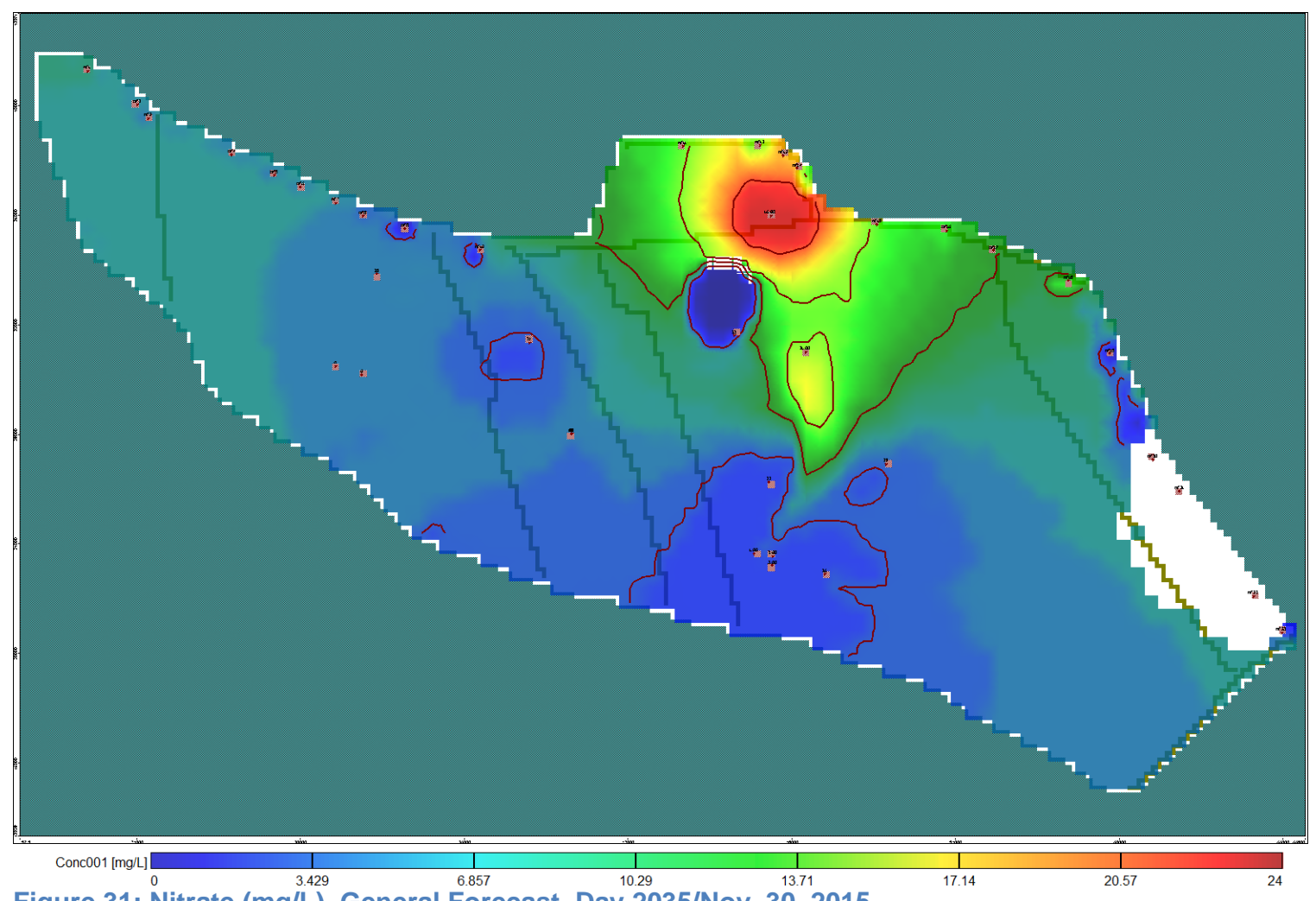

Figure 31: Nitrate (mg/L), General Forecast, Day 2035/Nov. 30, 2015 


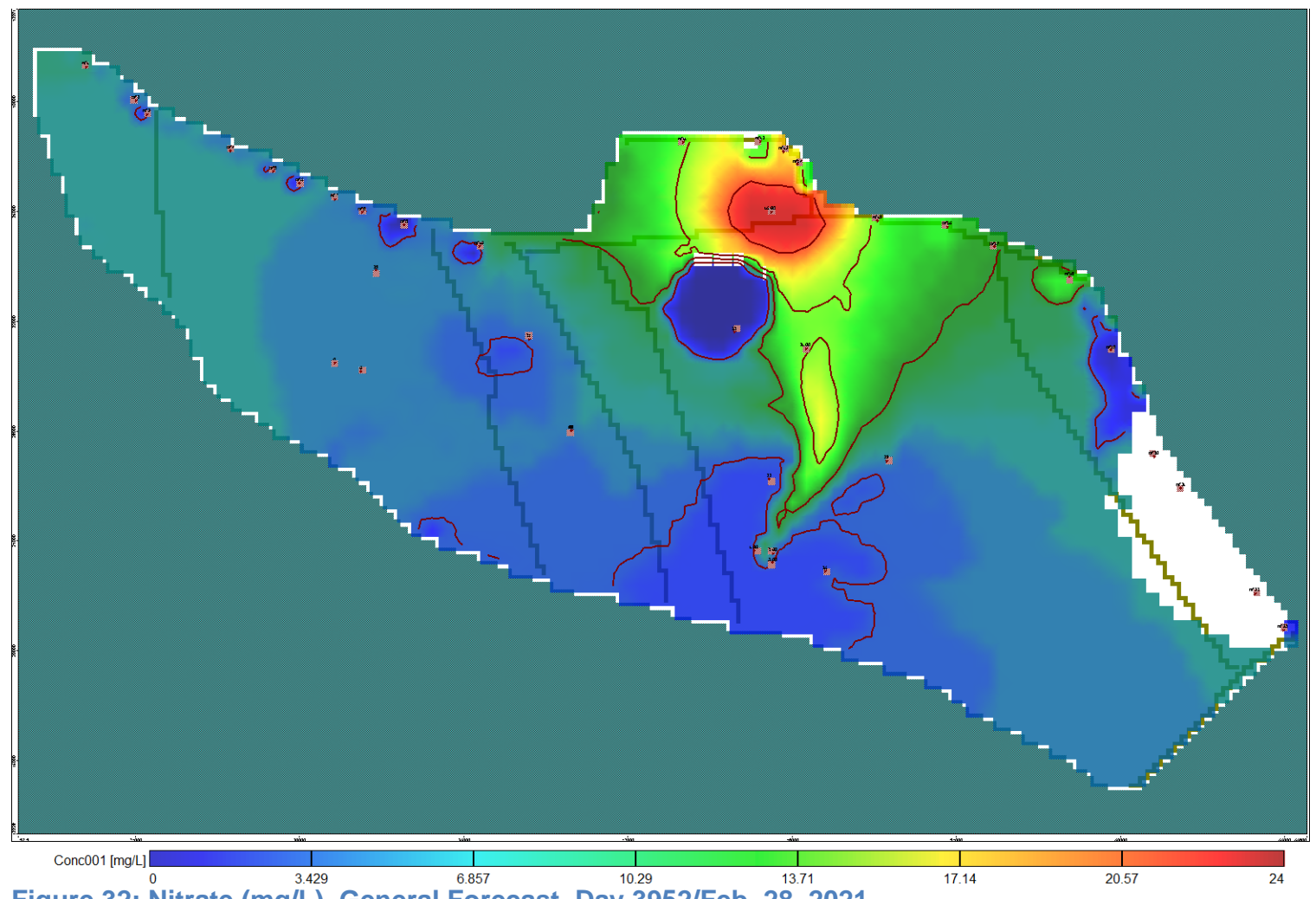

Figure 32: Nitrate (mg/L), General Forecast, Day 3952/Feb. 28, 2021

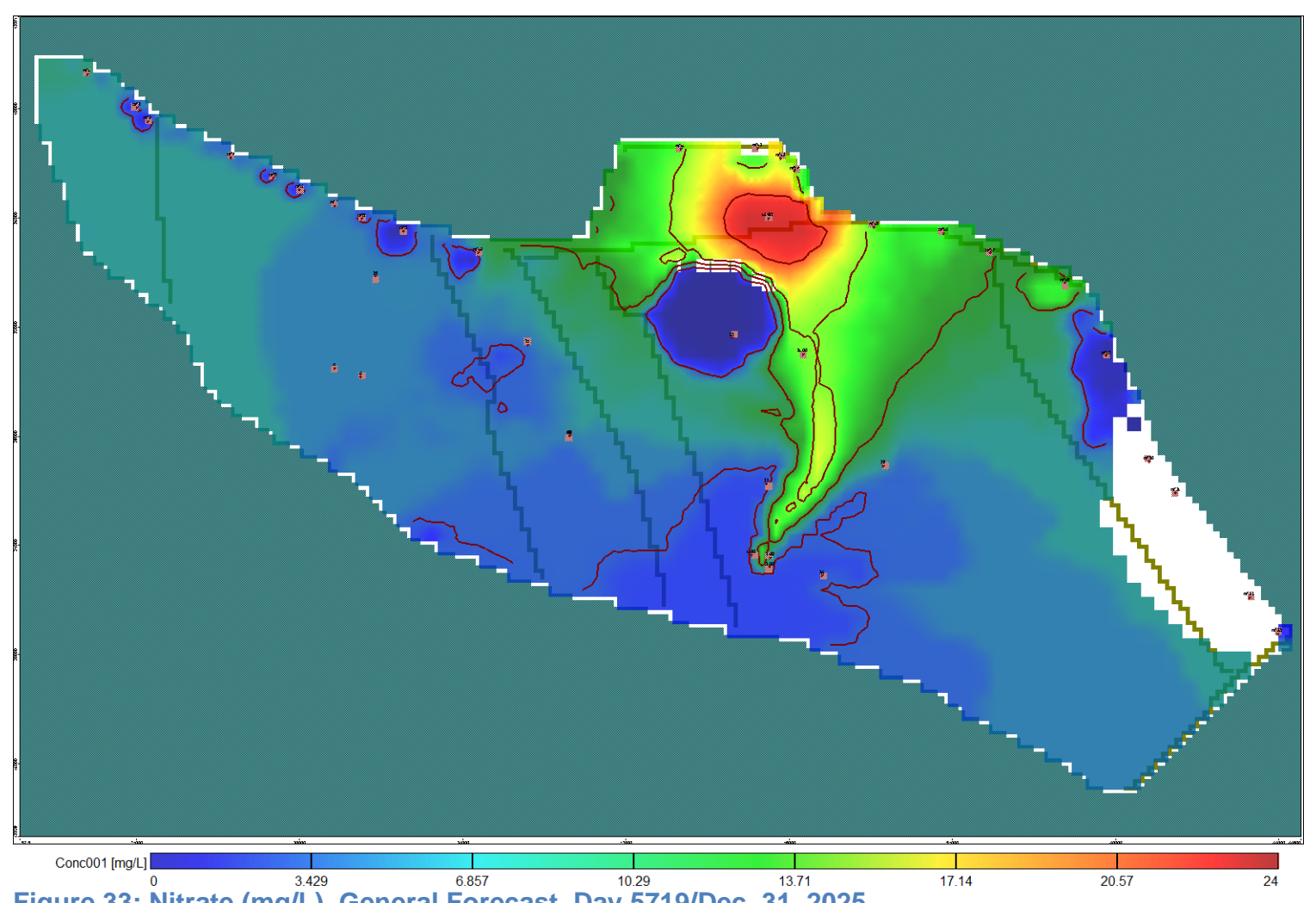

Figure 33: Nitrate (mg/L), General Forecast, Day 5719/Dec. 31, 2025 


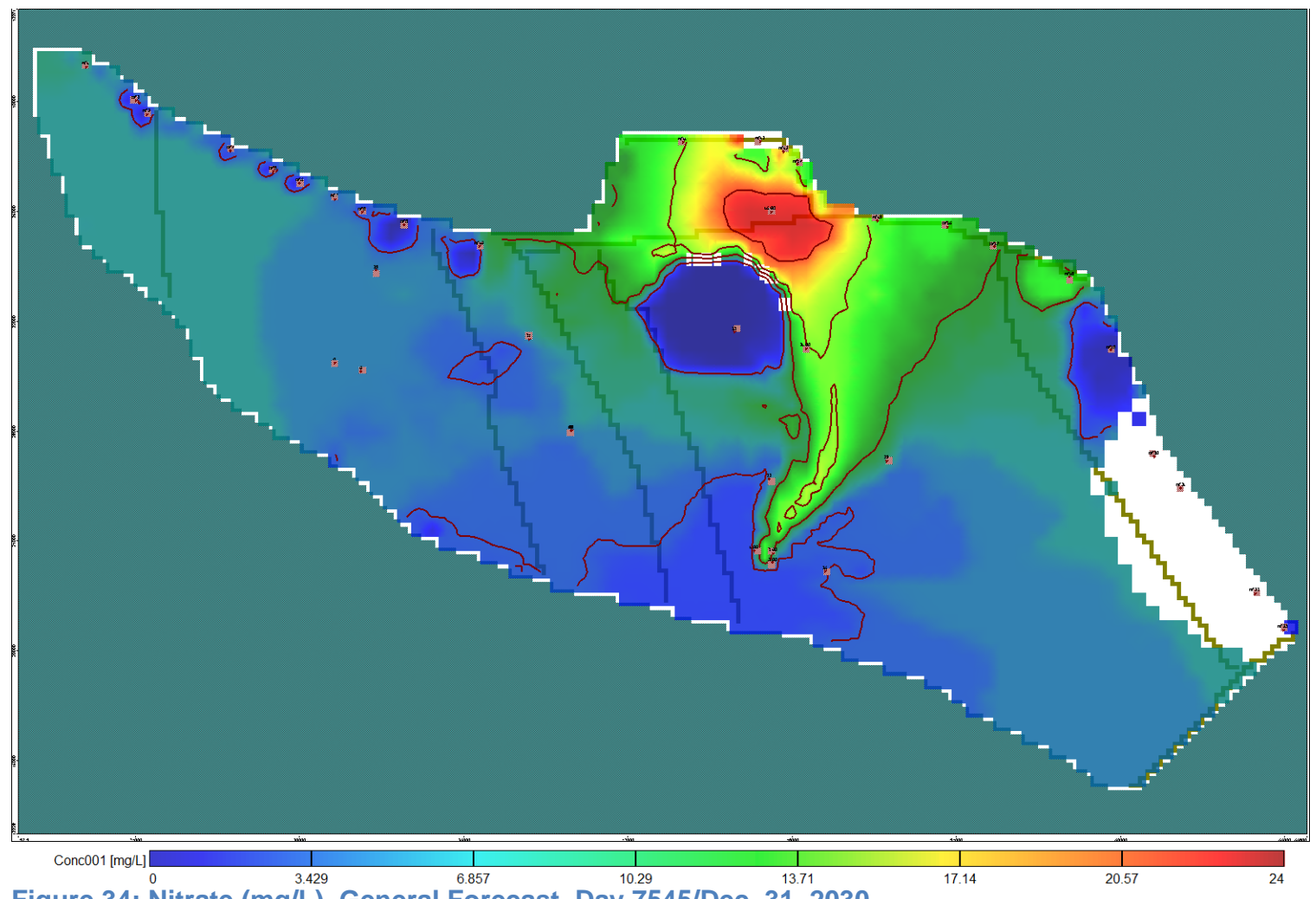

Figure 34: Nitrate (mg/L), General Forecast, Day 7545/Dec. 31, 2030

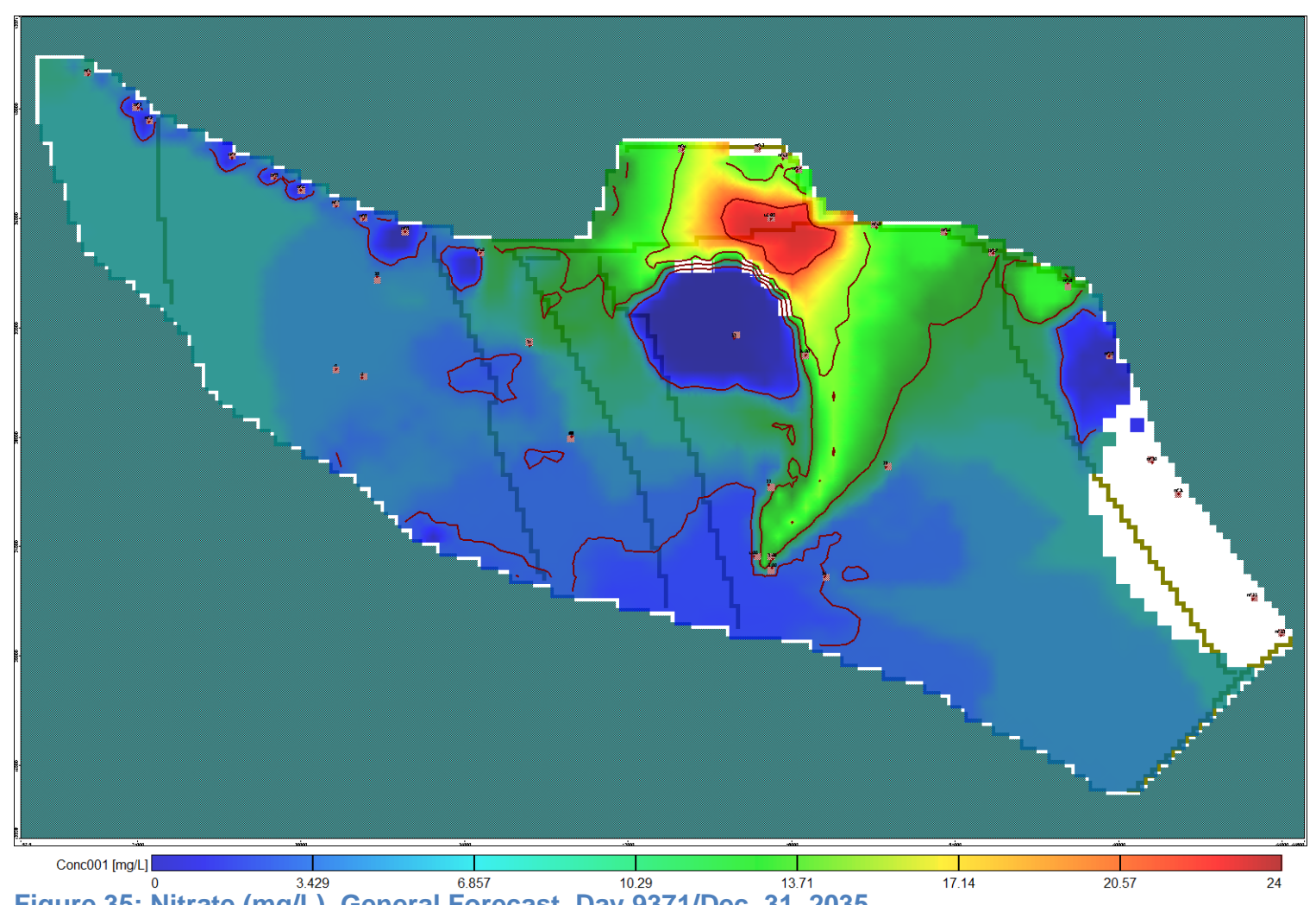

Figure 35: Nitrate (mg/L), General Forecast, Day 9371/Dec. 31, 2035 
When excessive pumping within the Cherry Valley region is introduced to the model, an overall decrease in nitrate concentration results in the production wells further south in the Beaumont Basin. In alternatives where excessive pumping occurs in or near the Cherry Valley region, groundwater with a higher nitrate concentration is extracted from the Beaumont Basin, leaving lower concentrations of nitrate available for transport to any production wells in the southern region of the Beaumont Basin.

Well 16, located within the Cherry Valley region, contributes a notable amount to the reduction of the nitrate concentrations available within the Beaumont Basin. However, when Well 21 is implemented into an alternative scenario, the long-term concentrations that appear at southern production wells are lowered even more significantly. Since well 21 is located between the Cherry Valley region and major production sites within the Beaumont Basin, it is likely that Well 21 is able to intercept much of the nitrate that would end up migrating to other production wells.

While Alternative 6 lowers nitrate concentrations the best among alternatives where adjusted artificial recharge is combined with heavy pumping of Wells 16 and 21, this alternative does not account for treated water recharge. Given the pumping rates in Wells 16 and 21, the volume of water extracted would essentially offset the water artificially recharged within the Noble Creek Recharge Ponds. Since these ponds are installed to help recover drawdown in the Beaumont Basin, Alternative 6 falls short of preserving the water table. Figure 36 through Figure 40 show nitrate concentrations for Alternative 6. 


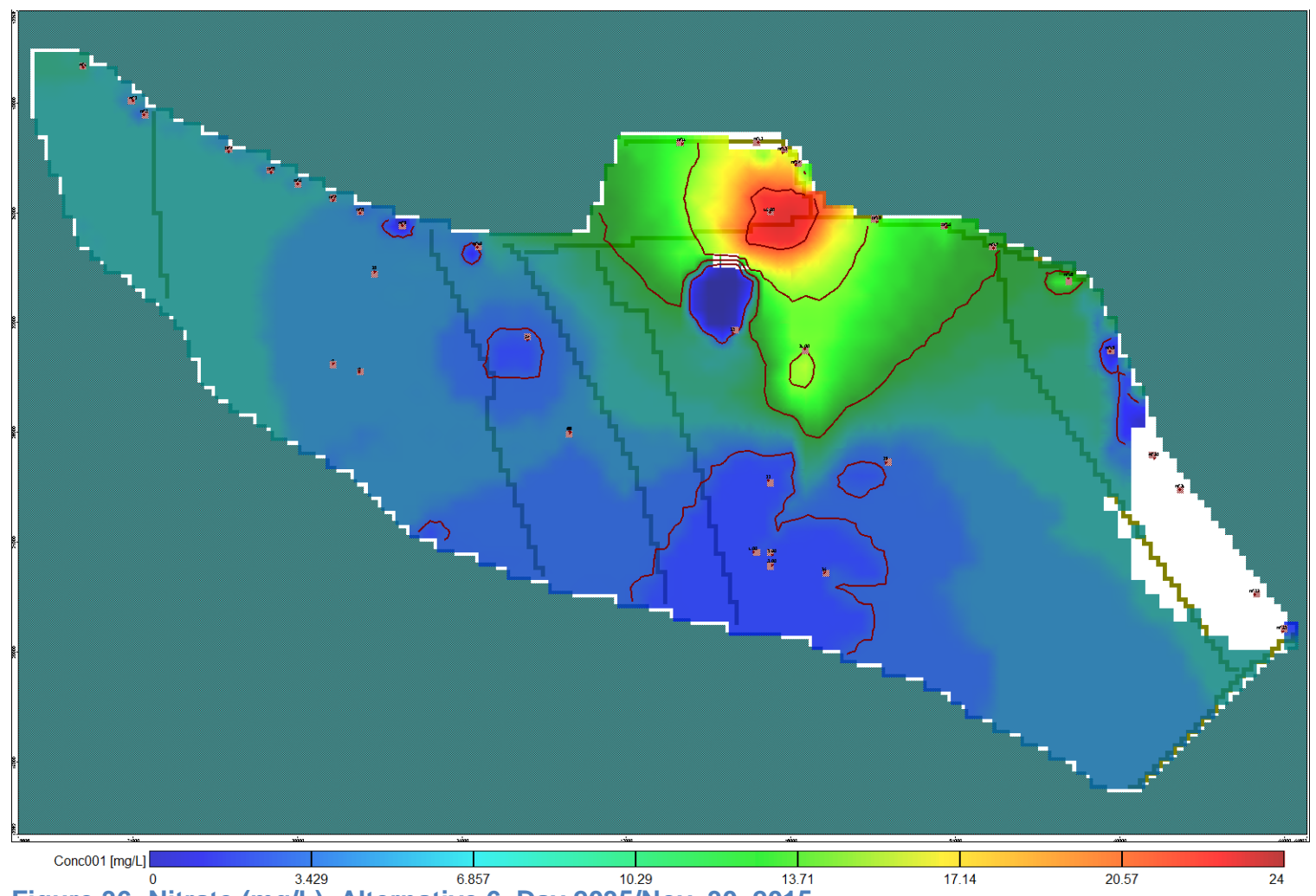

Figure 36: Nitrate (mg/L), Alternative 6, Day 2035/Nov. 30, 2015

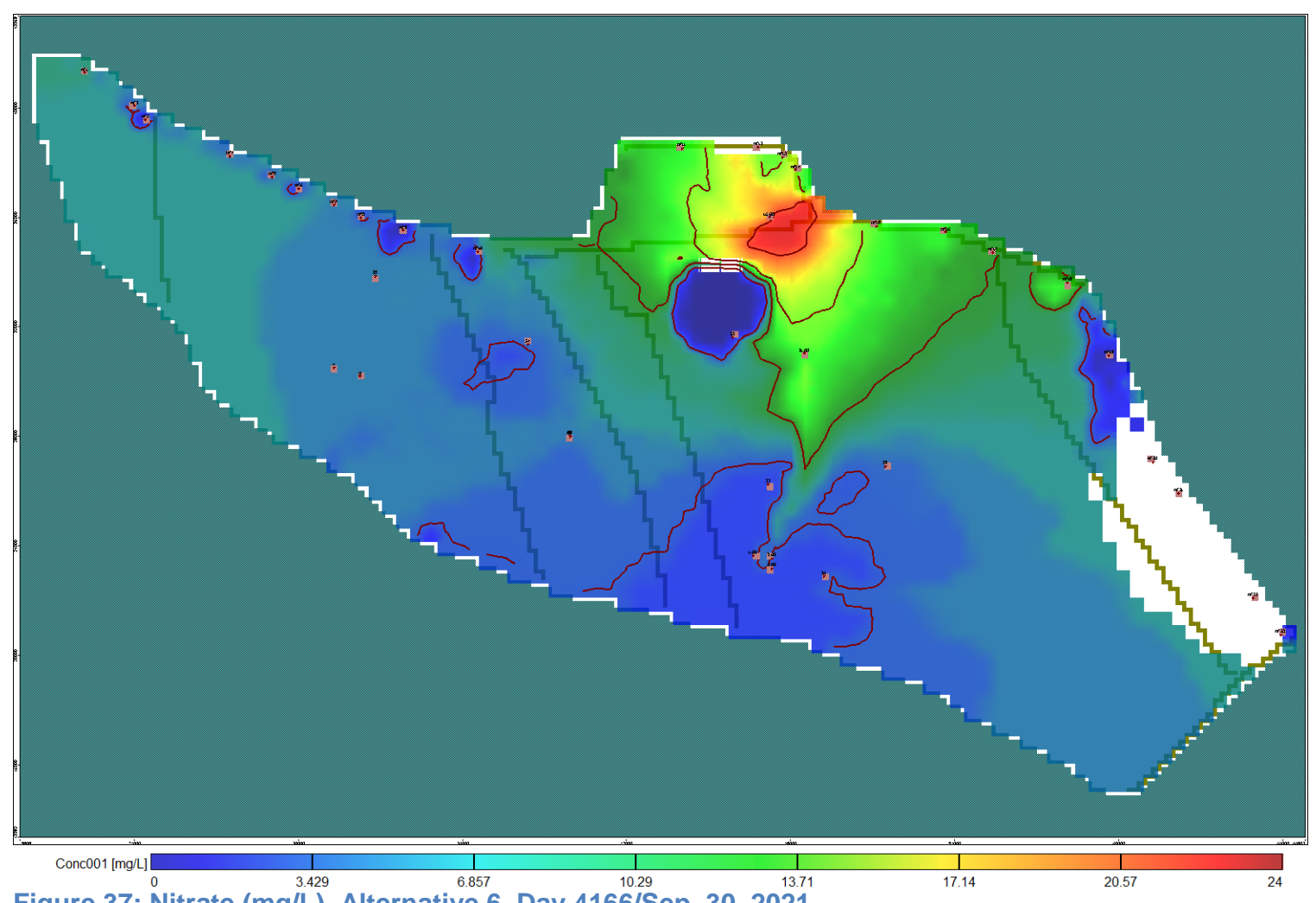

Figure 37: Nitrate (mg/L), Alternative 6, Day 4166/Sep. 30, 2021 


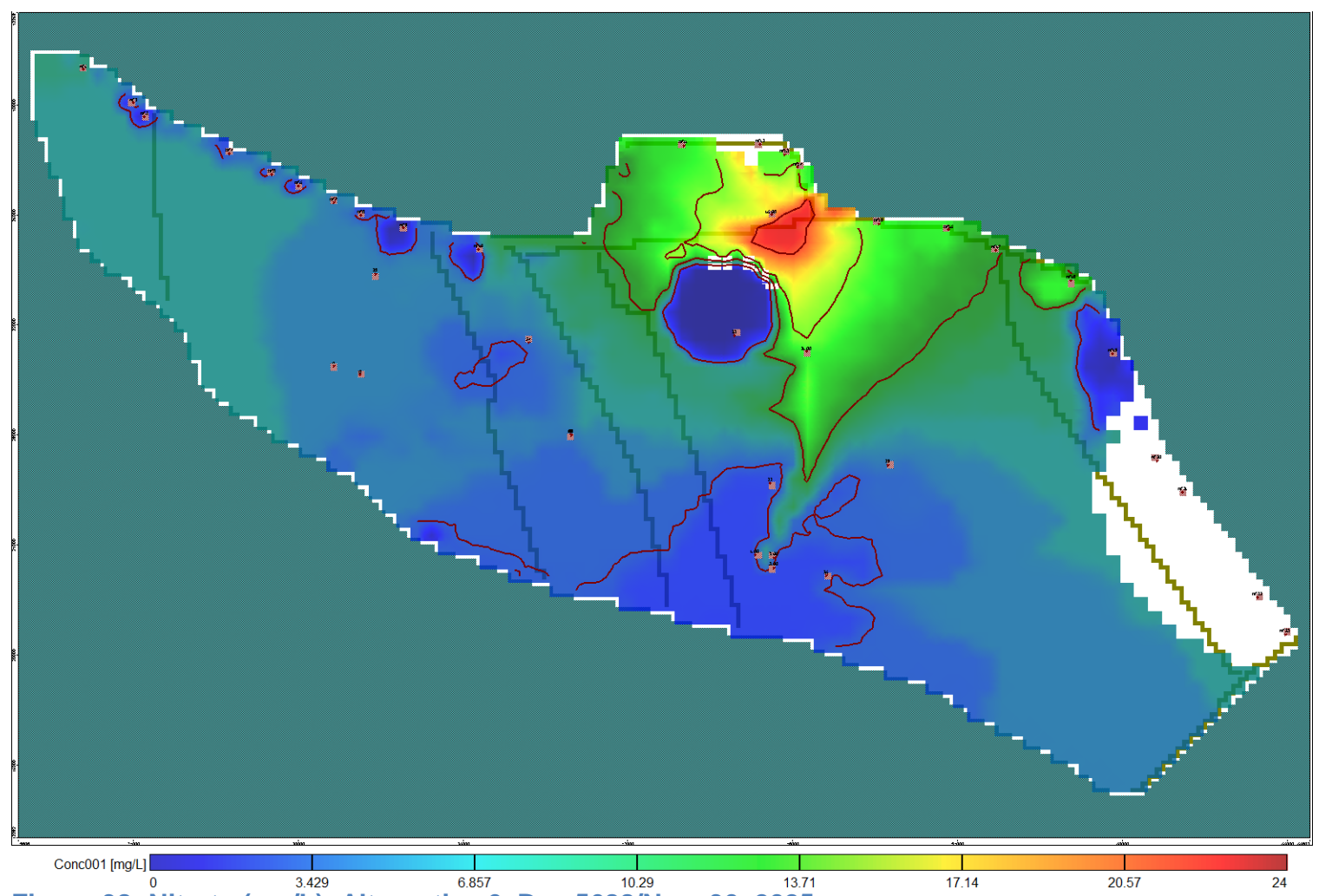

Figure 38: Nitrate (mg/L), Alternative 6, Day 5688/Nov. 30, 2025

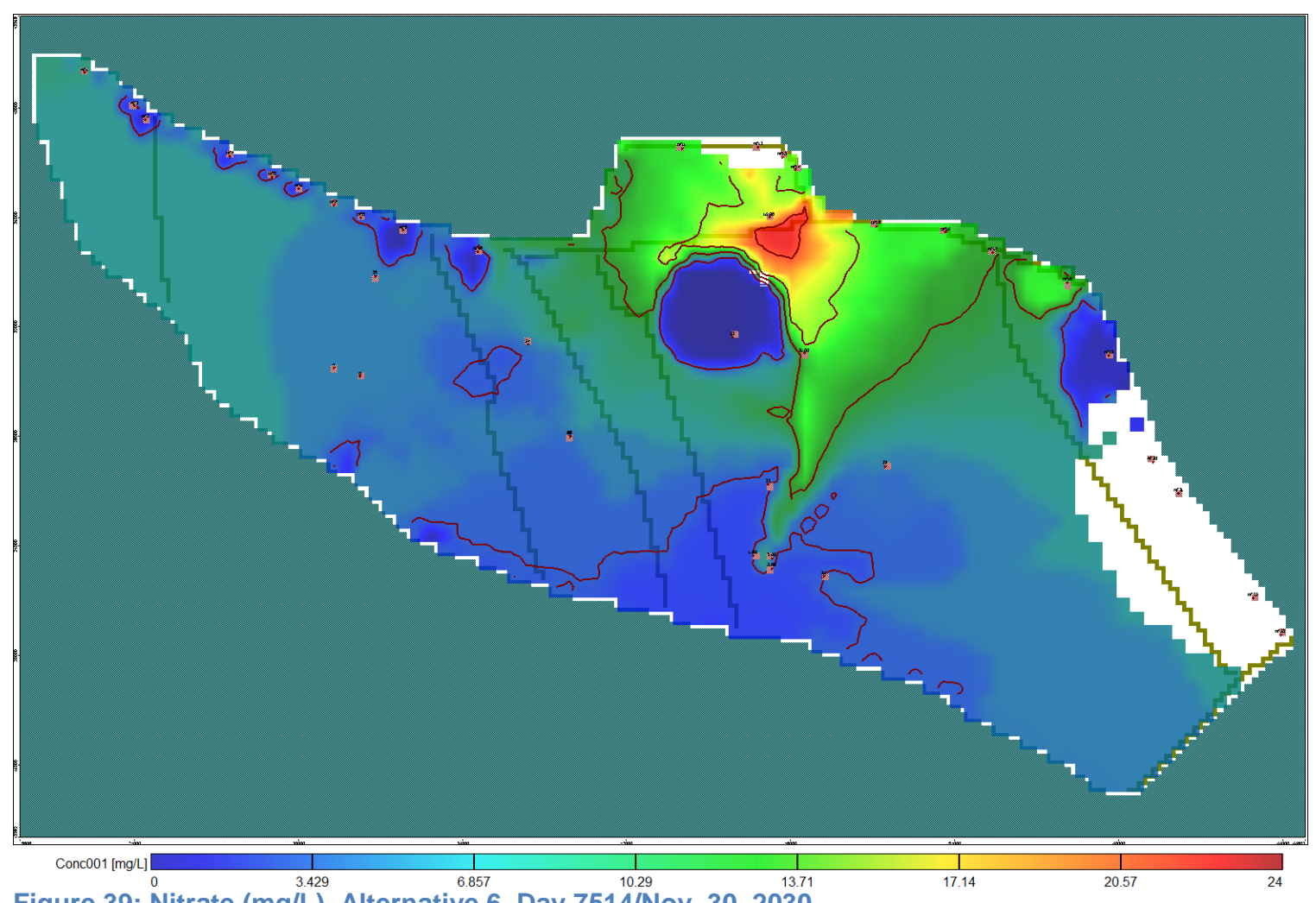

Figure 39: Nitrate (mg/L), Alternative 6, Day 7514/Nov. 30, 2030 


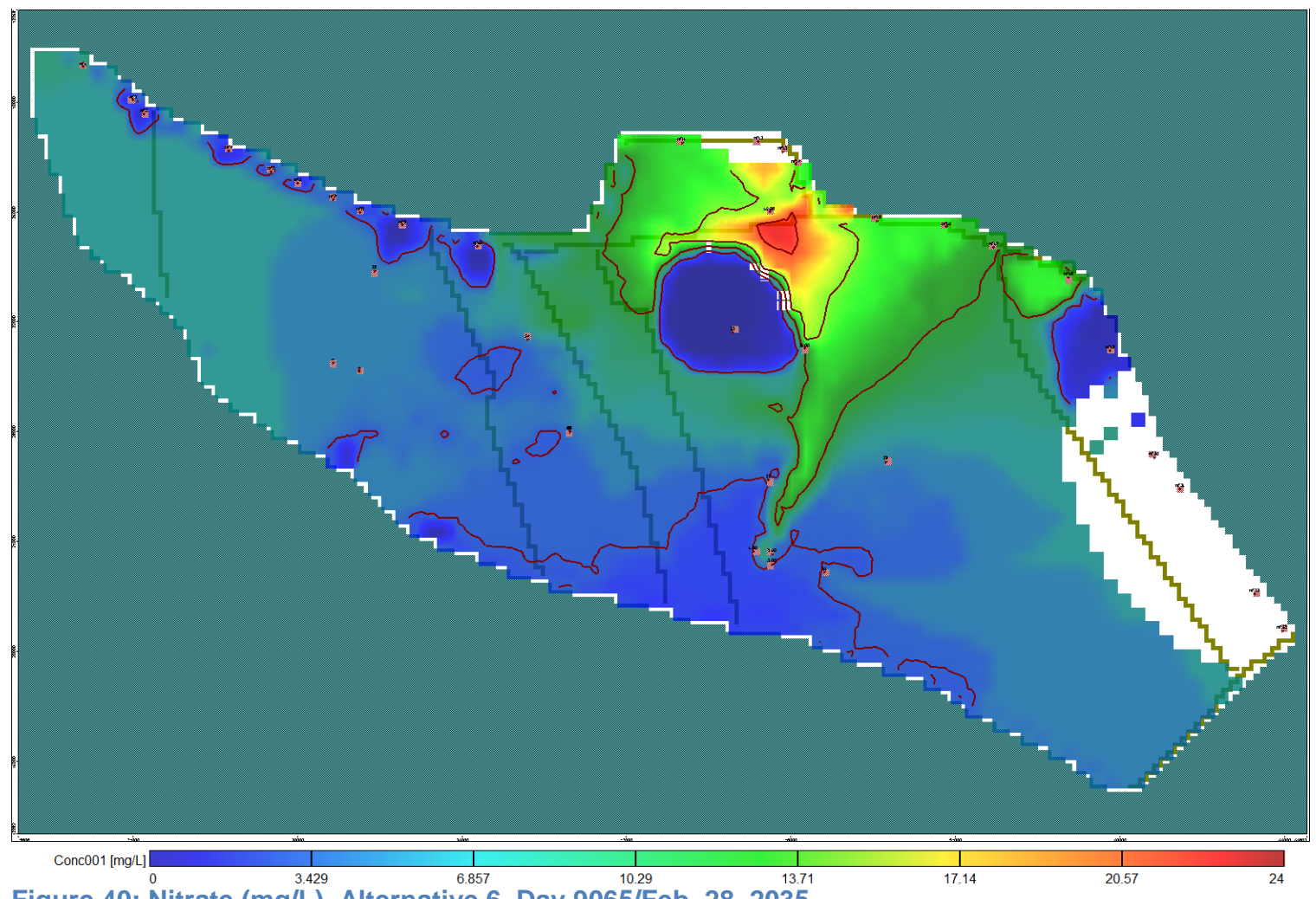

Figure 40: Nitrate (mg/L), Alternative 6, Day 9065/Feb. 28, 2035

As shown in Figure 36 through Figure 40, the initial nitrate concentrations within and just south of the Cherry Valley region are greatly reduced by the pumping of Wells 16 and 21 and the artificial recharge a the Noble Creek Recharge Ponds.

Assuming that the land is available for constructing additional recharge ponds, the recharge expansion alternatives provide the lowest concentrations of nitrate at production wells without using excessive pumping or expensive treatment to reduce nitrates. Figure 41 through Figure 50 show the changes in concentration for both recharge alternatives, as stated in their captions. 


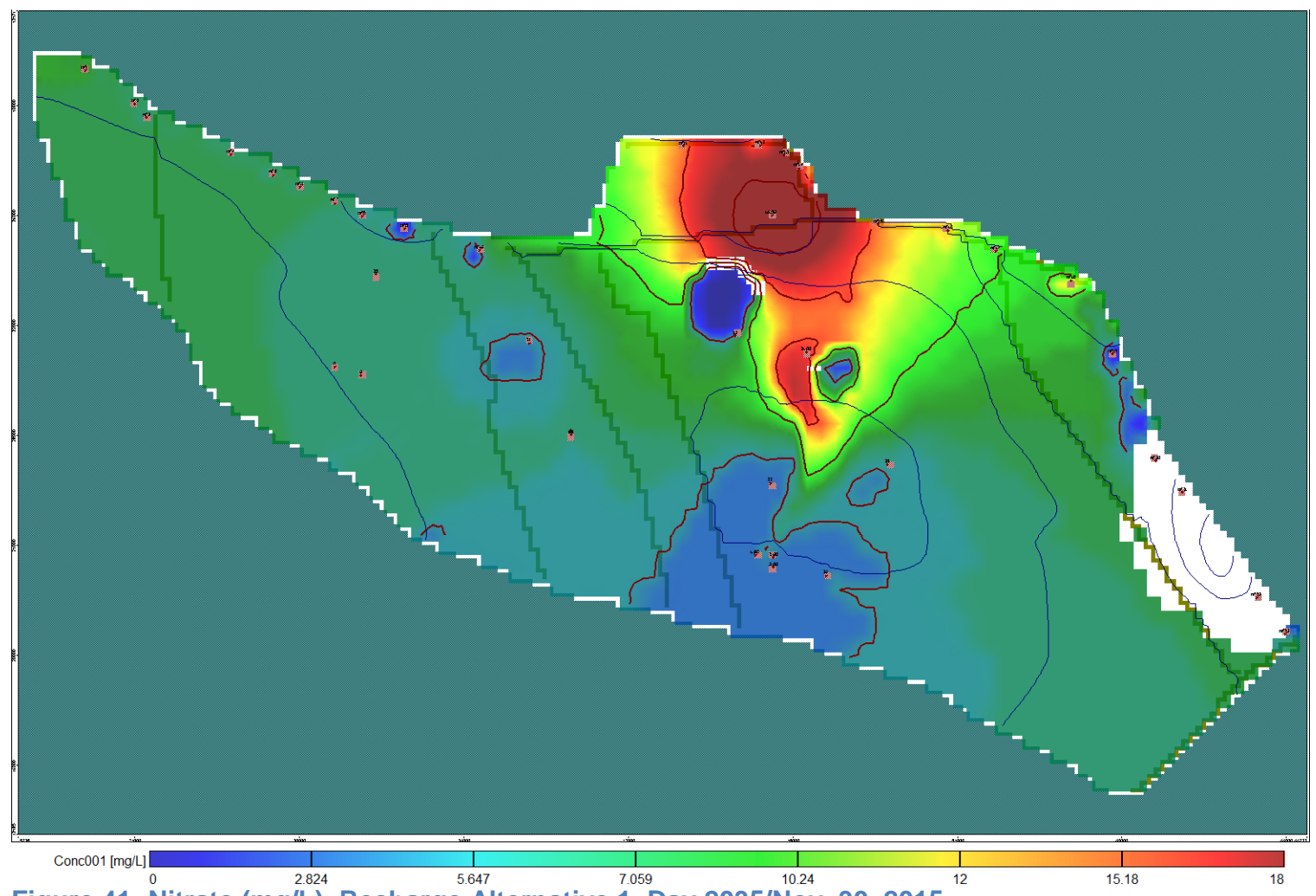

Figure 41: Nitrate (mg/L), Recharge Alternative 1, Day 2035/Nov. 30, 2015

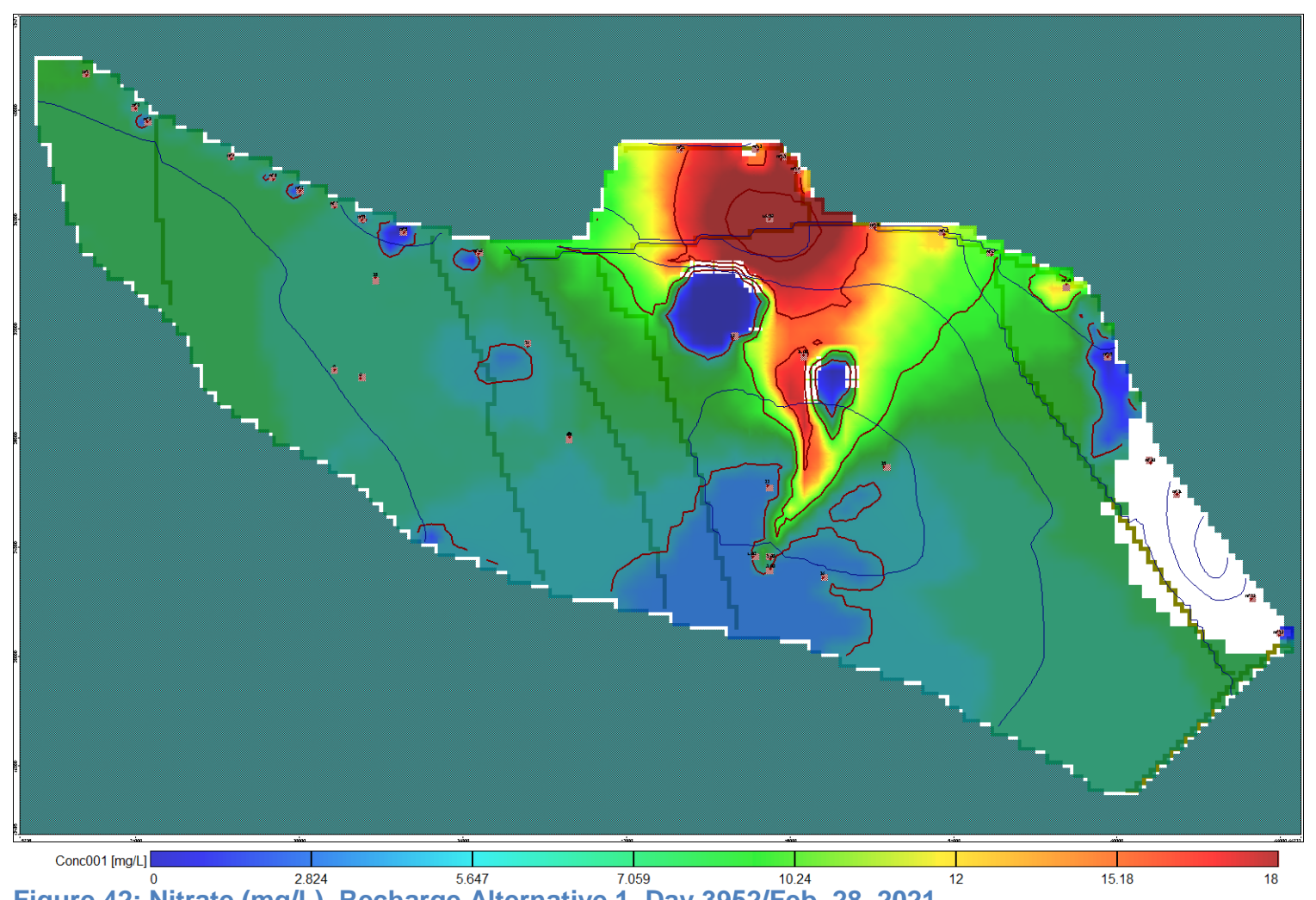

Figure 42: Nitrate (mg/L), Recharge Alternative 1, Day 3952/Feb. 28, 2021 


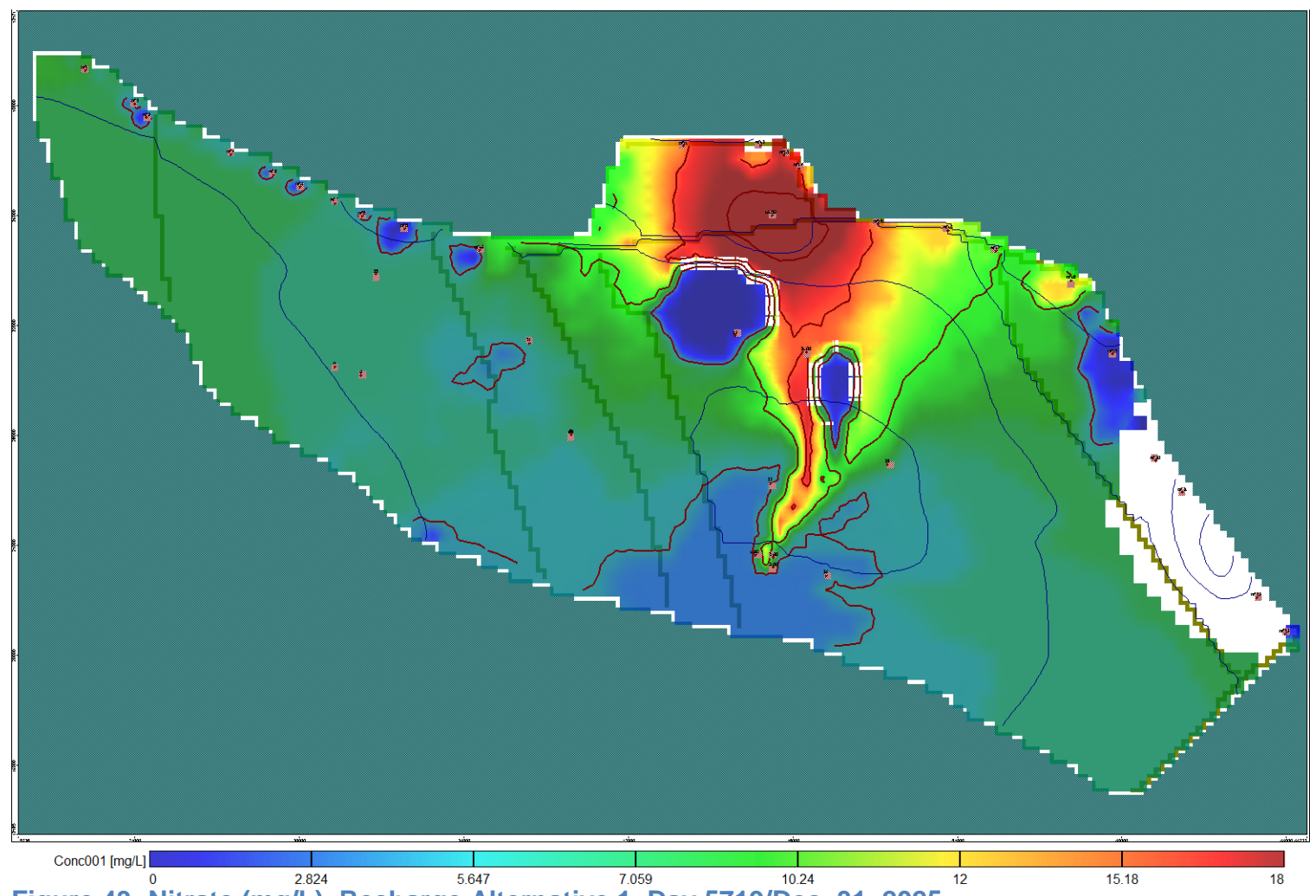

Figure 43: Nitrate (mg/L), Recharge Alternative 1, Day 5719/Dec. 31, 2025

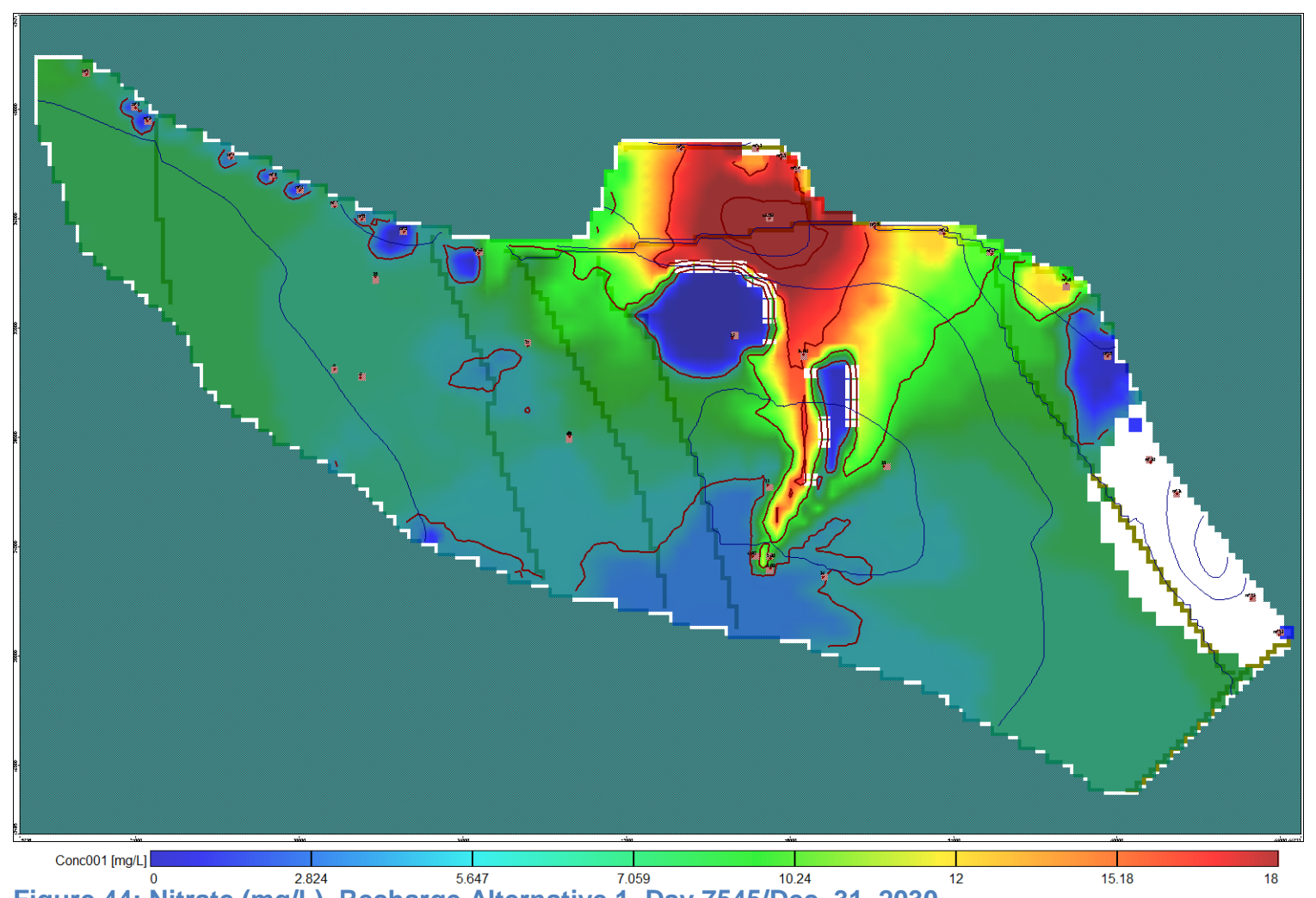

Figure 44: Nitrate (mg/L), Recharge Alternative 1, Day 7545/Dec. 31, 2030 


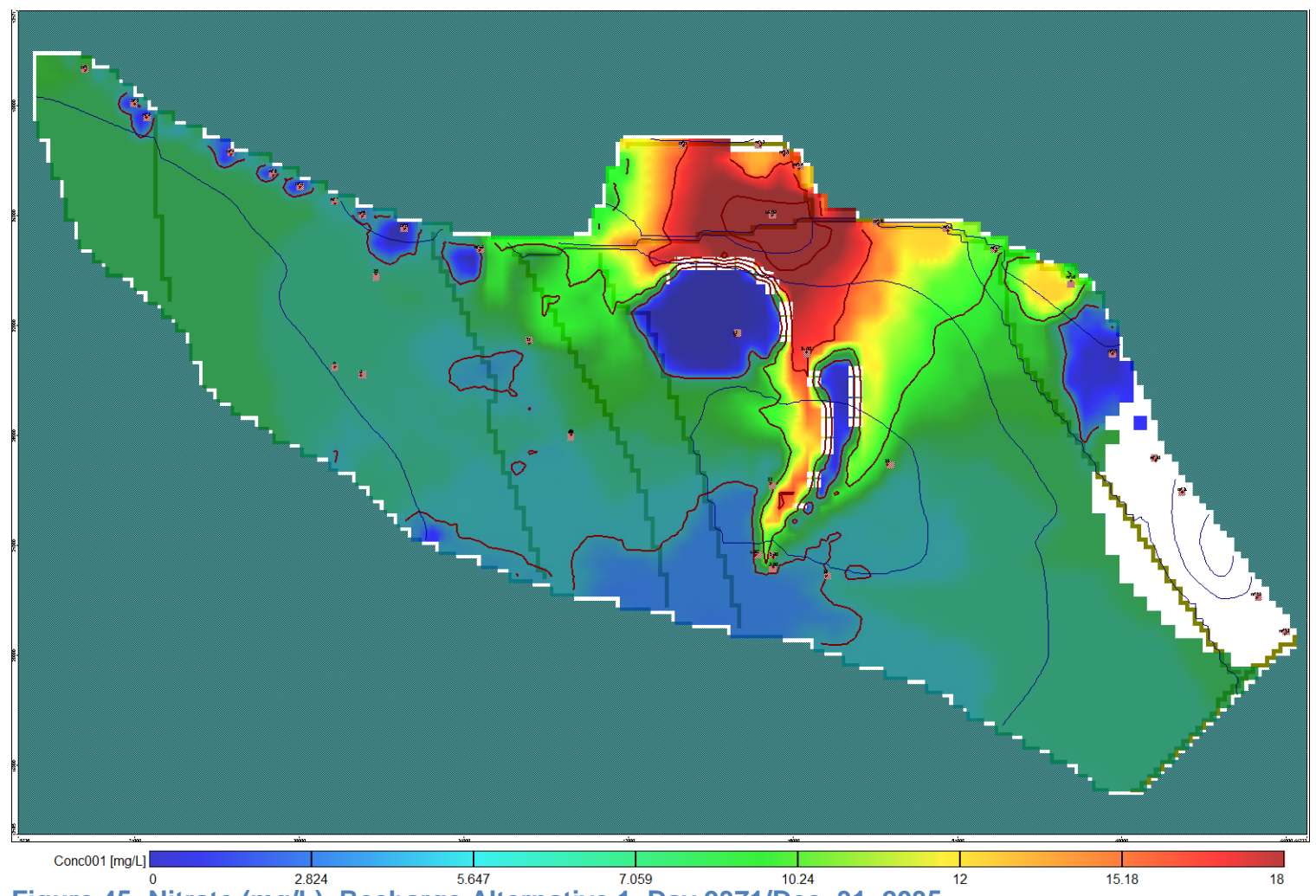

Figure 45: Nitrate (mg/L), Recharge Alternative 1, Day 9371/Dec. 31, 2035

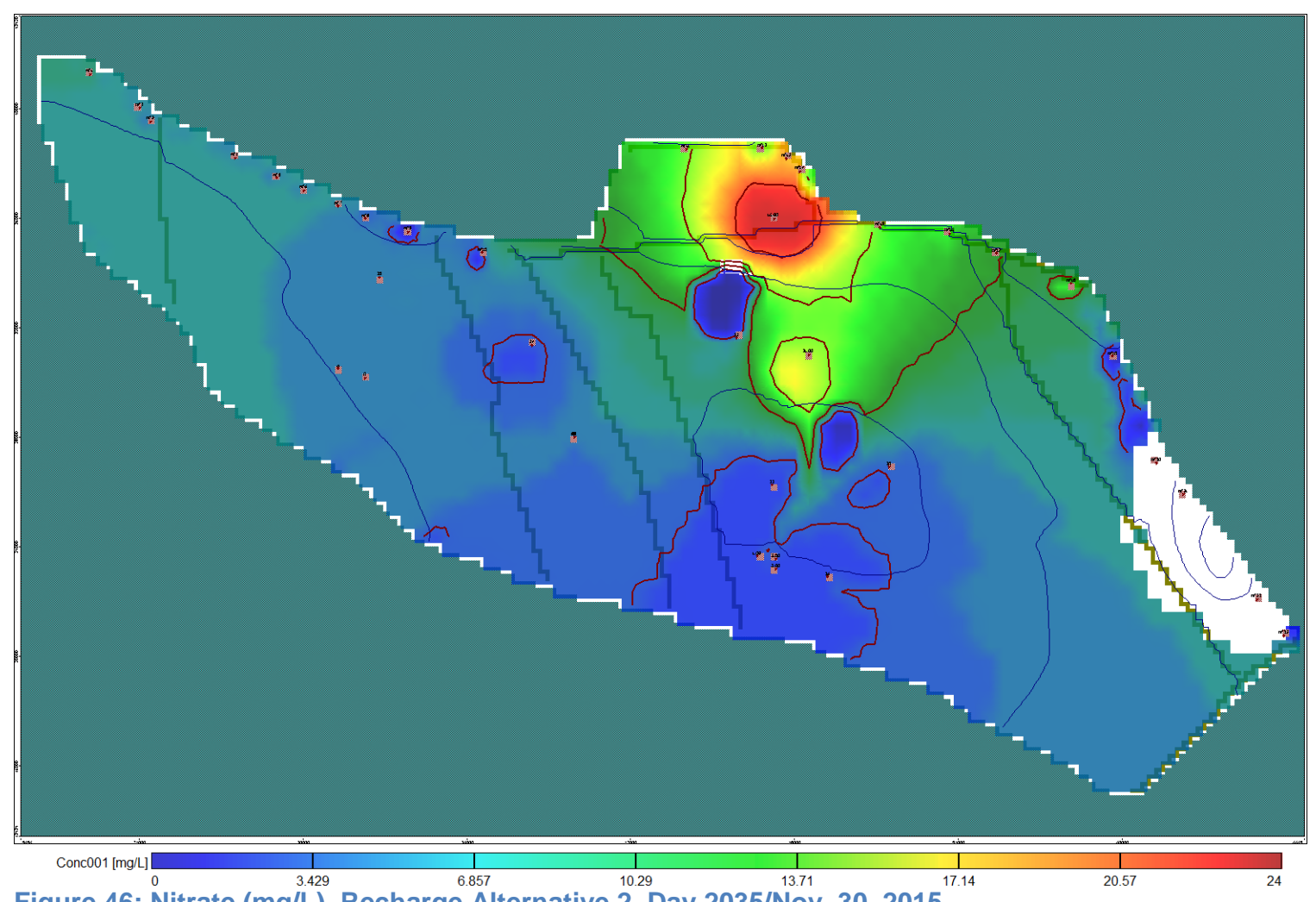

Figure 46: Nitrate (mg/L), Recharge Alternative 2, Day 2035/Nov. 30, 2015 


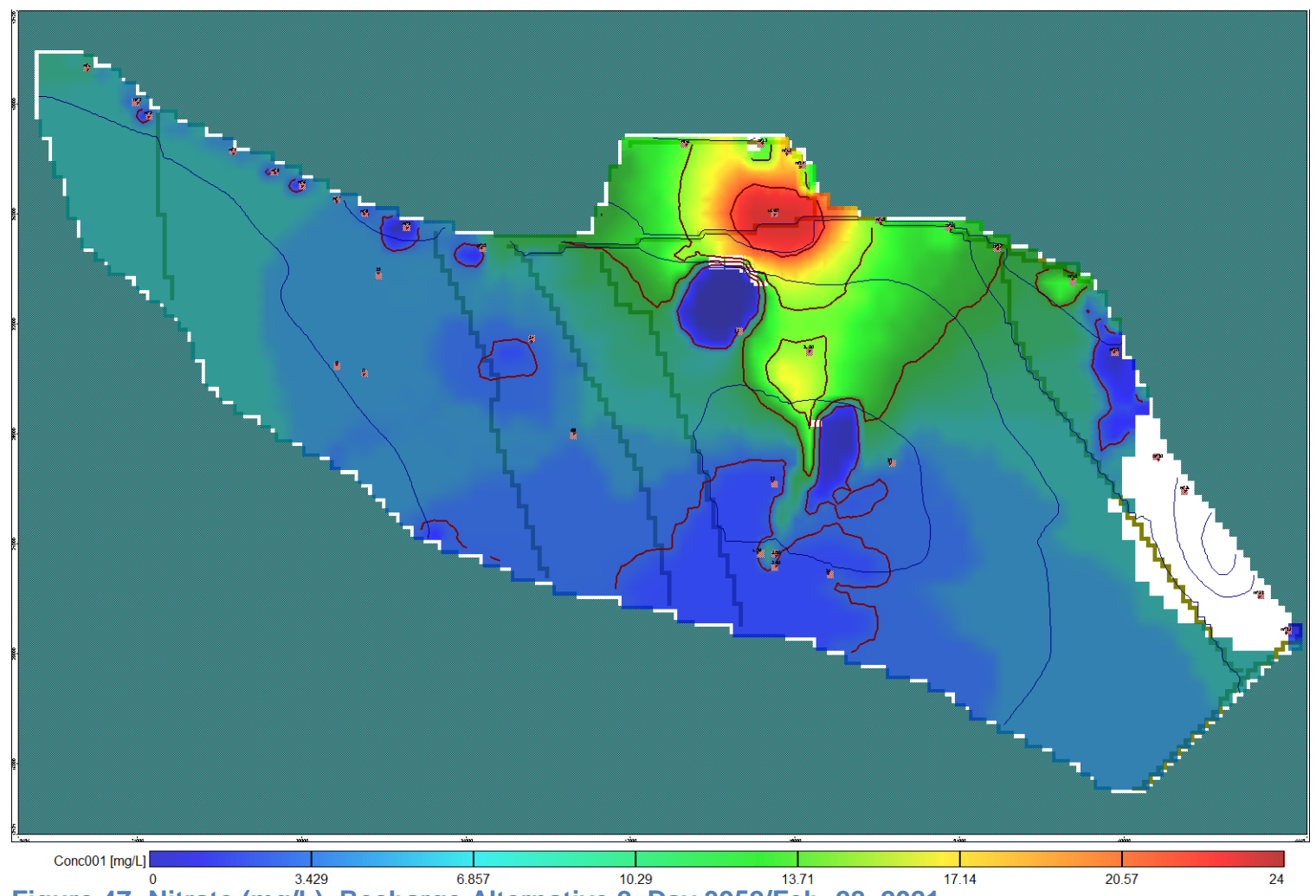

Figure 47: Nitrate (mg/L), Recharge Alternative 2, Day 3952/Feb. 28, 2021

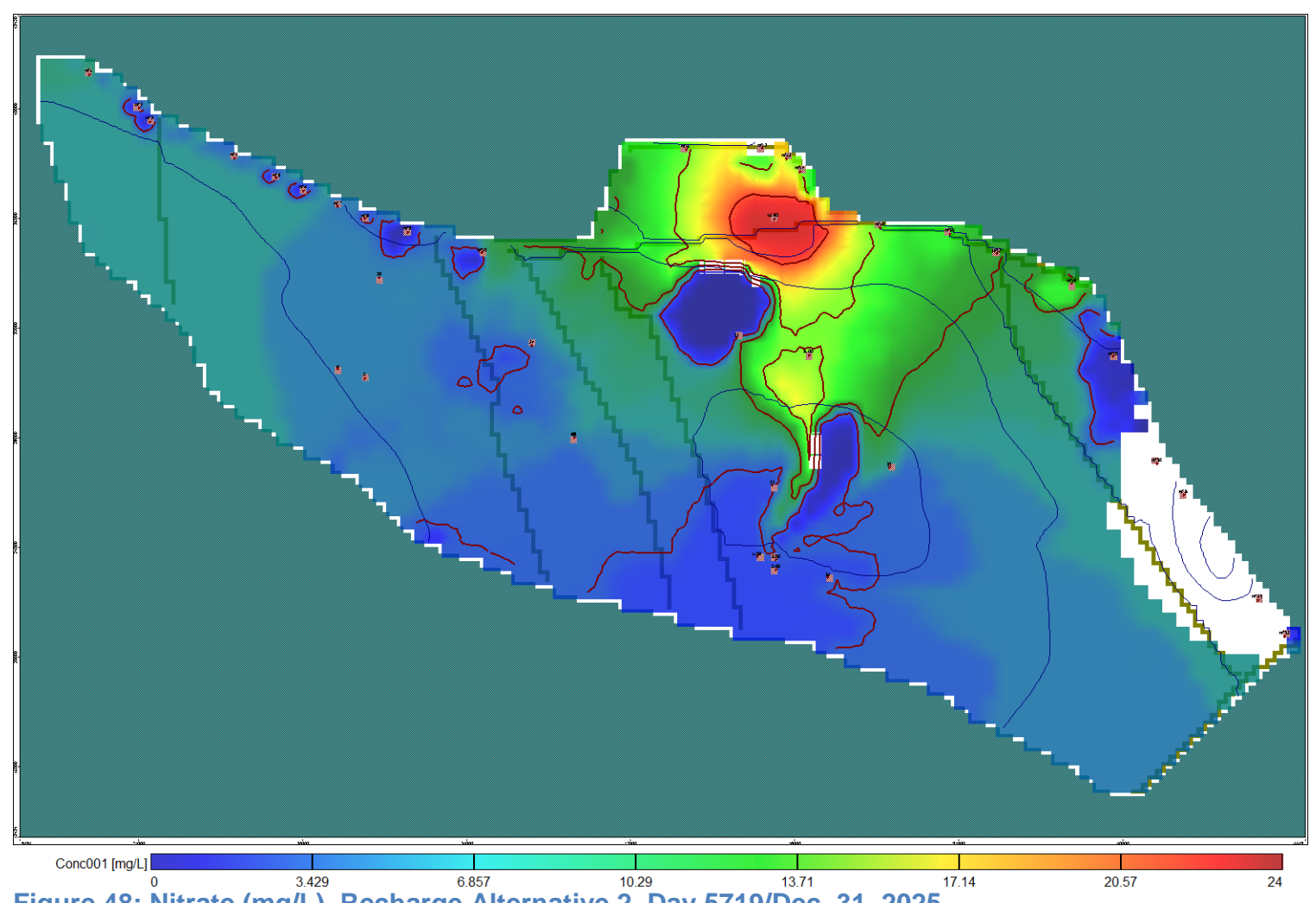

Figure 48: Nitrate (mg/L), Recharge Alternative 2, Day 5719/Dec. 31, 2025 


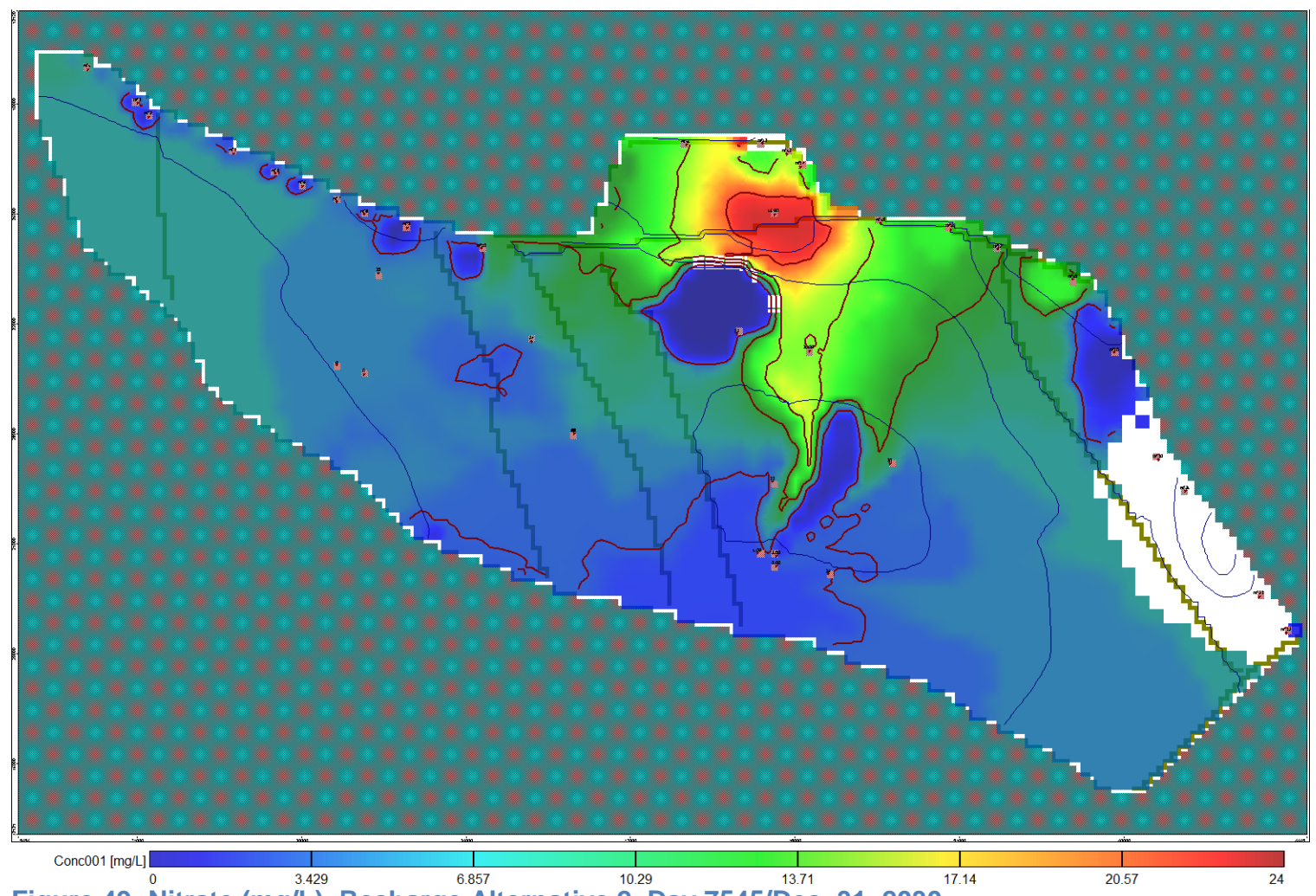

Figure 49: Nitrate (mg/L), Recharge Alternative 2, Day 7545/Dec. 31, 2030

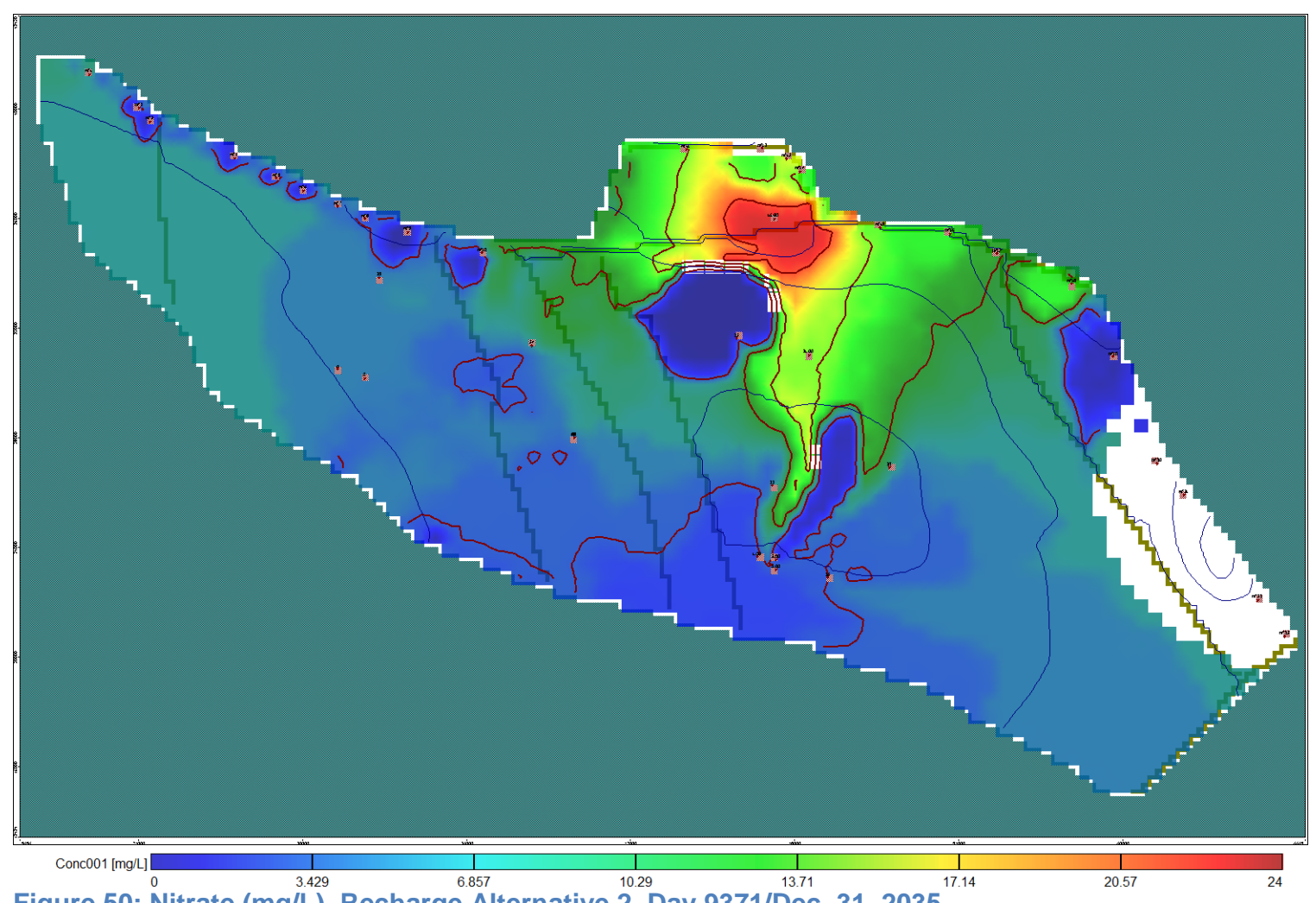

Figure 50: Nitrate (mg/L), Recharge Alternative 2, Day 9371/Dec. 31, 2035 
By placing additional artificial recharge ponds south of the Cherry Valley region, some additional dilution occurs for the plume of nitrate that extends south of the Cherry Valley region. In both recharge alternatives, water artificially recharge in a new recharge pond is drawn toward major production wells in the southern Beaumont region, providing lower concentrations of nitrate over time. For both recharge alternatives, it is important to note that the total artificial recharge rate of $0.75 \mathrm{ft} /$ day is maintained, meaning that SWP deliveries comparable to current deliveries could provide results like those in recharge alternatives 1 and 2 .

For all of the alternatives tested, the nitrate concentrations measured at each BCVWD production well within the Beaumont Basin is documented in Table 13: Nitrate concentrations for Projected Alternatives on page 113.

Finally, a model of the nitrate loading into the Beaumont Basin from septic tanks and mountain front recharge shows a small effect on Layer 4, the layer with the most hydraulic activity. However, concentrations in Layer 3 show that under the Cherry Valley region, it is possible to have high concentrations of nitrate, with the maximum nitrate concentrations approaching the septic tank loading rate of $50 \mathrm{mg} / \mathrm{L}$. It is possible that the high nitrate concentrations in layer 3 are due to the low permeability layer below the Cherry Valley region and the Cherry Valley Fault, which runs along the south end of the Cherry Valley area. The fault and perching layer may inhibit nitrate from percolating further down into the aquifer, and also help to keep nitrate from flowing horizontally into the rest of the Beaumont Basin. 


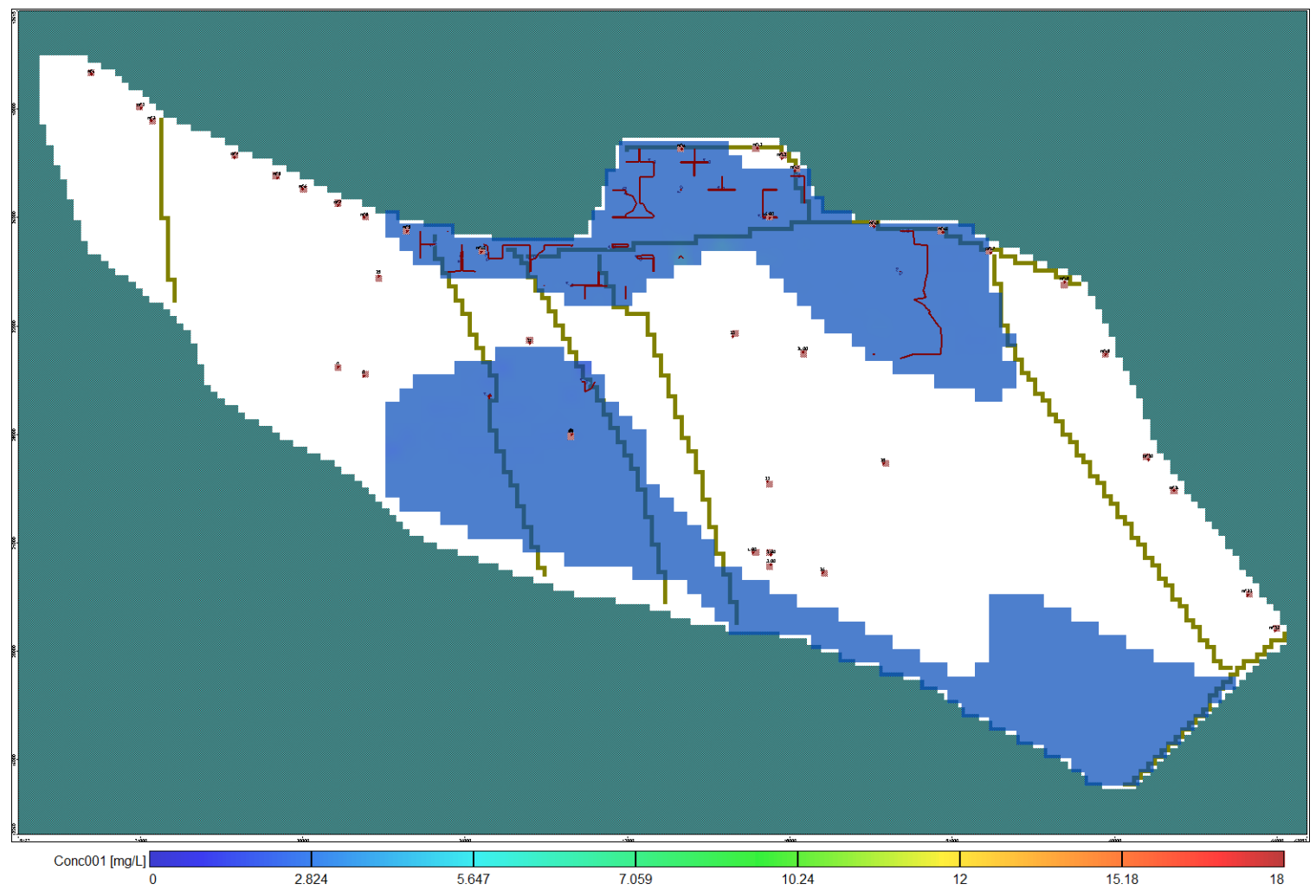

Figure 51: Nitrate (mg/L), Septic tank loading, Day 26/May 31, 2010, Lay. 3

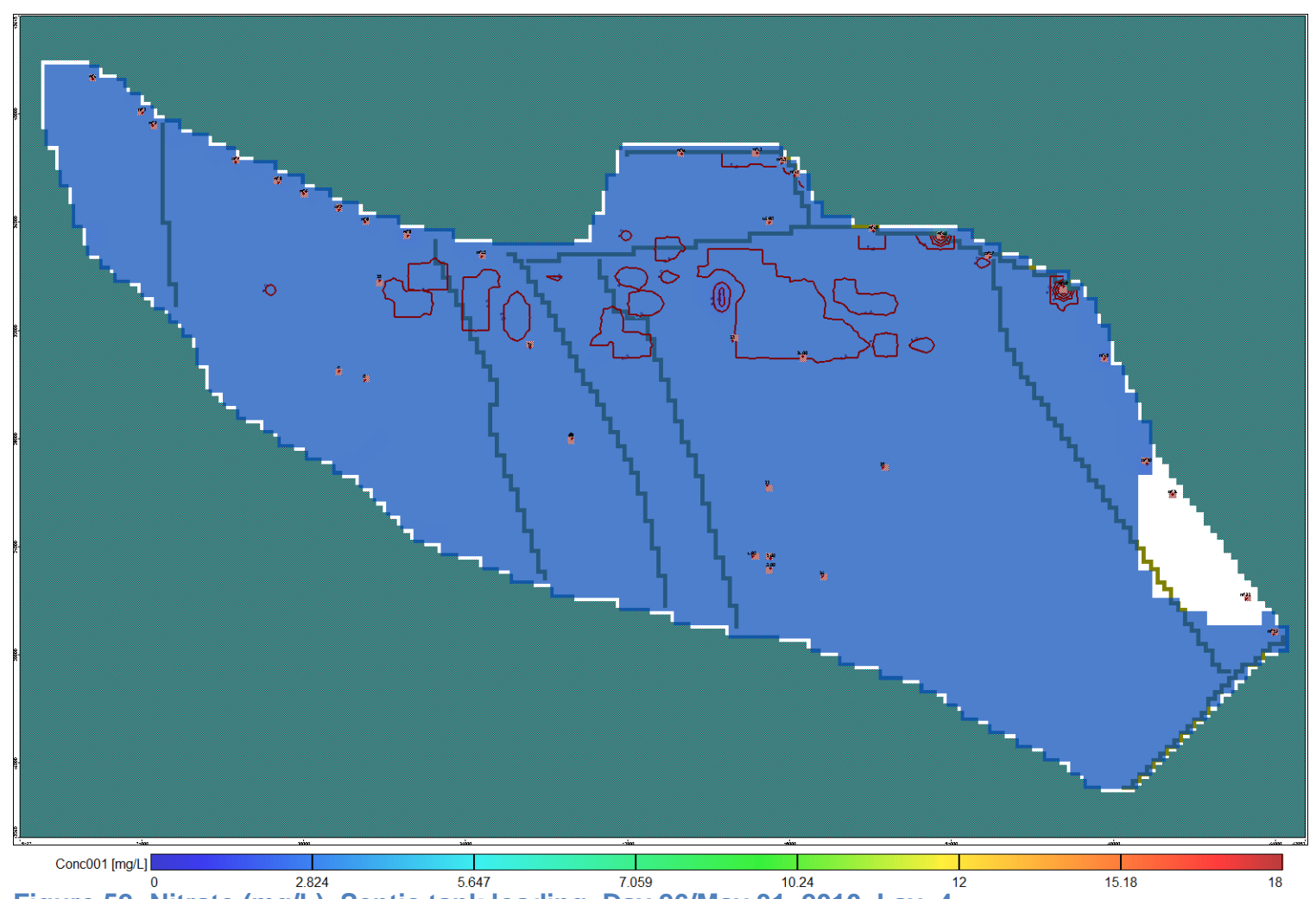

Figure 52: Nitrate (mg/L), Septic tank loading, Day 26/May 31, 2010, Lay. $4^{12}$ 


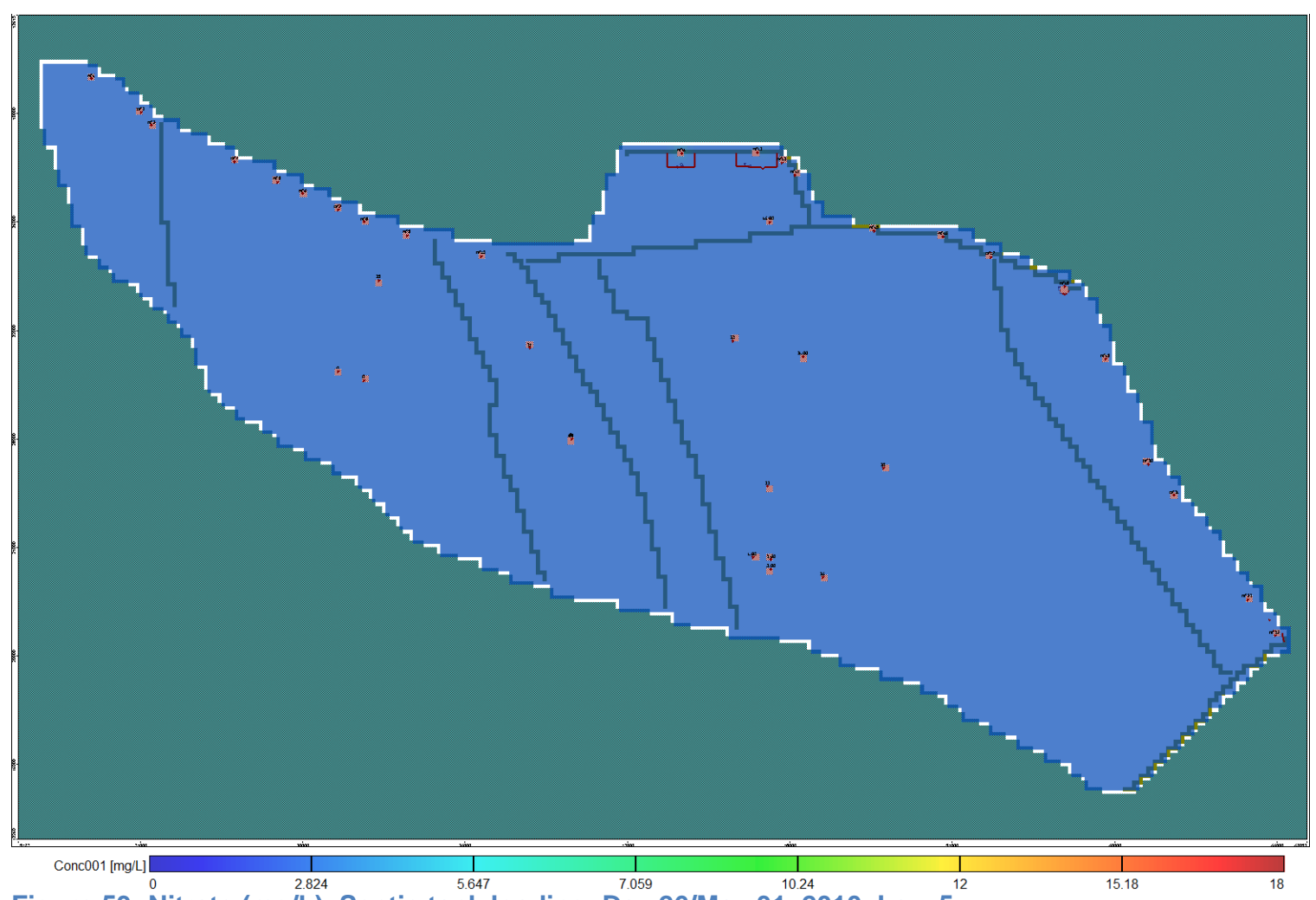

Figure 53: Nitrate (mg/L), Septic tank loading, Day 26/May 31, 2010, Lay. 5

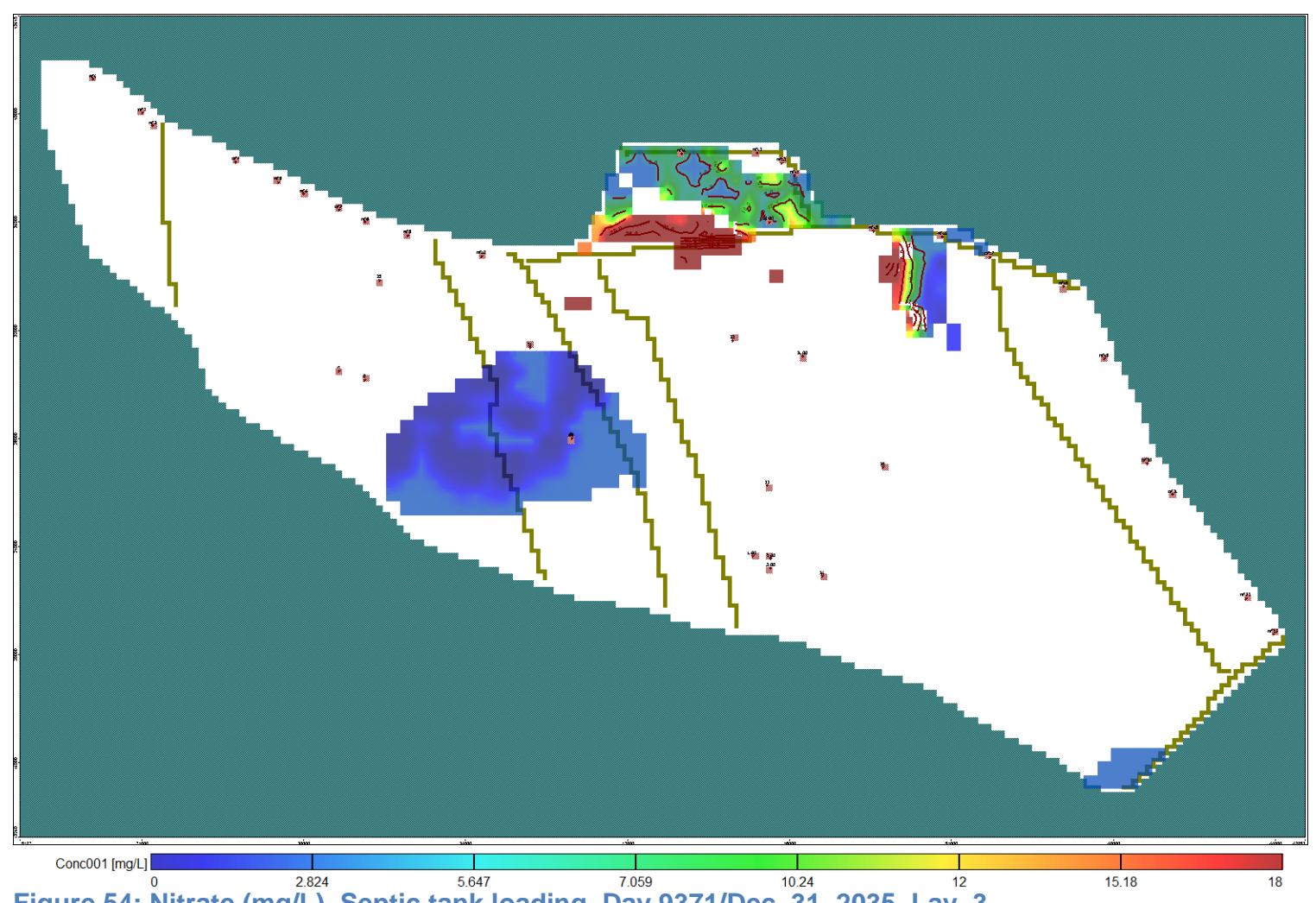

Figure 54: Nitrate (mg/L), Septic tank loading, Day 9371/Dec. 31, 2035, Lay. 3 


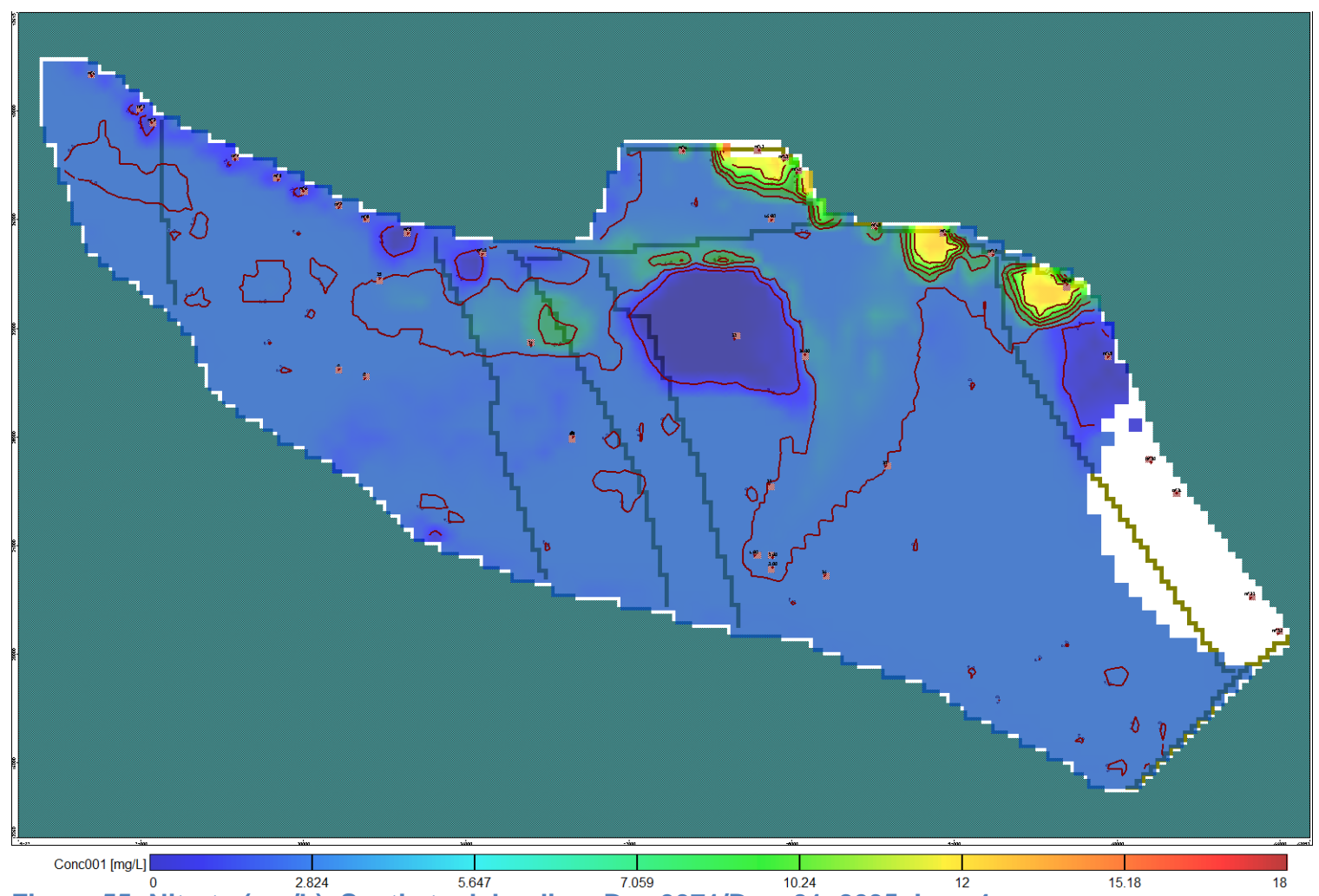

Figure 55: Nitrate (mg/L), Septic tank loading, Day 9371/Dec. 31, 2035, Lay. 4

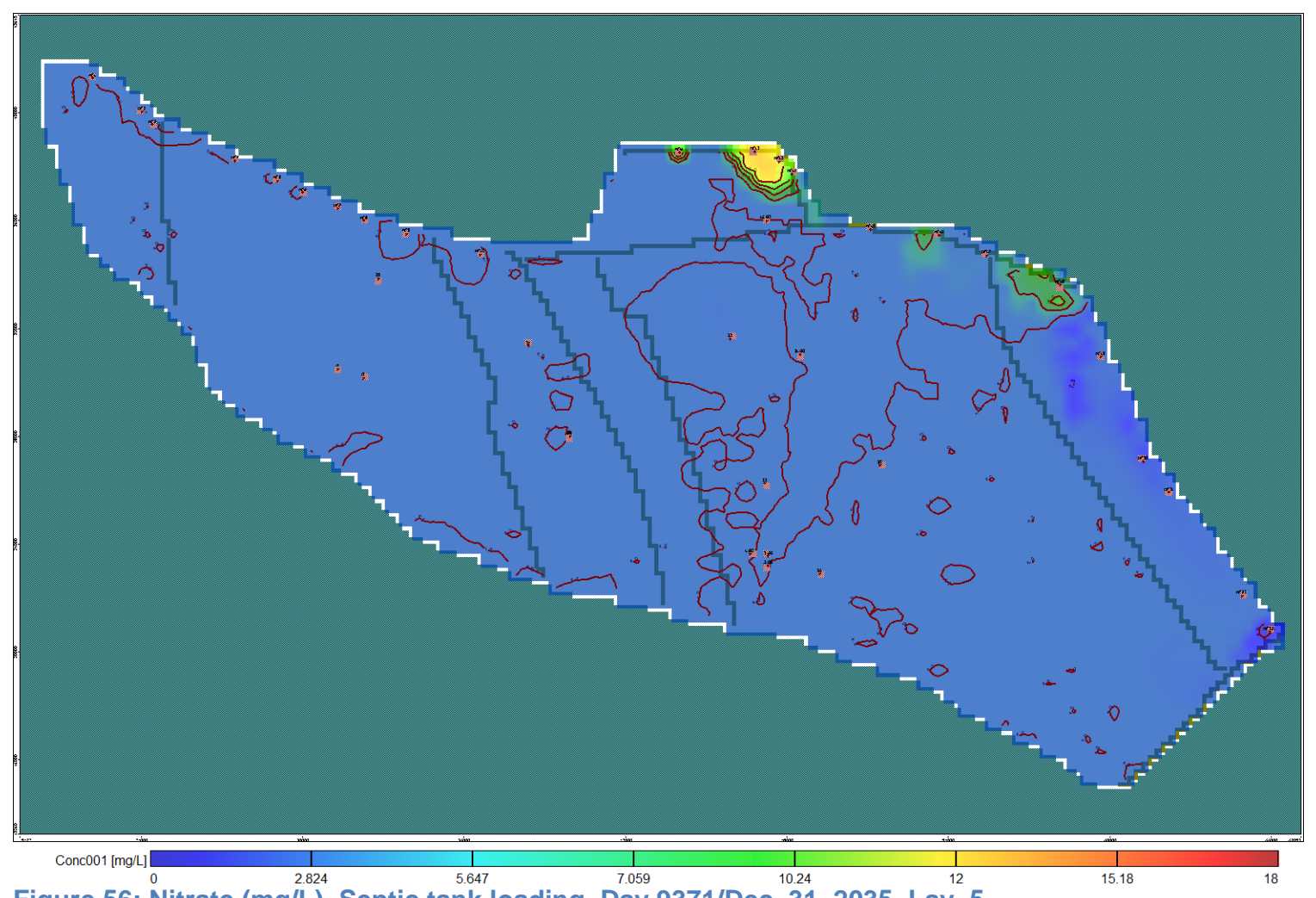

Figure 56: Nitrate (mg/L), Septic tank loading, Day 9371/Dec. 31, 2035, Lay. 5 


\section{Chapter 9: Conclusions and Recommendations}

\section{Summary of Results}

Overall, the models and alternative scenarios show that while the levels of nitrate within the Beaumont Basin are not currently great enough to violate any MCLs set by the EPA, nitrate is capable of moving through the Beaumont Basin from the Cherry Valley region. As the populations of Beaumont and Cherry Valley increase, there is a greater demand for water. If all of the municipal water is provided by pumping groundwater from the Beaumont Basin, a steeper groundwater gradient can form, thus creating potential for increased flows to the southern regions of the Beaumont Basin. This steeper gradient would allow for the increased transport of nitrate from the Cherry Valley region in the northern section of the Beaumont Basin to many of the higher-capacity production wells that operate in the southern region of the Beaumont Basin.

To mitigate increased drawdown of the water table within the Beaumont Basin, the BCVWD has implemented artificial recharge ponds. These ponds allow SWP water deliveries to be percolated into the Beaumont Basin, where these water deliveries can help maintain a water balance within the Beaumont Basin.

In addition to providing more water within the Beaumont Basin, the Noble Creek Recharge Project ponds also inhibit some of the nitrate flows to the southern portion of the Beaumont Basin. This recharged water either dilutes nitrate plumes that leave the Cherry Valley region or keeps contaminated groundwater within the Cherry Valley region by creating less potential for 
southward flow against the Cherry Valley fault that runs along the southern boundary of the Cherry Valley region.

However, the models and scenarios within this study show that a smaller nitrate plume can be pulled from south of the Cherry Valley region and towards major production wells. There are a few methods that can be implemented to help reduce the concentrations of nitrate that reach production wells in the southern Beaumont Basin.

One method would be a heavy increase in pumping from production wells within and just south of the Cherry Valley region. In effect, this practice would pull groundwater with higher concentrations of nitrate out of the Beaumont Basin. This extracted, contaminated water might then be treated and recharged back into the Beaumont Basin; however, common treatments for nitrate contamination, including ion exchange systems and reverse osmosis treatment, are costly. If contaminated water were simply removed from the Beaumont Basin, the volume of extracted water would be comparable to the volume of water recharged through the Noble Creek Recharge Project ponds, which would negatively offset the recharge ponds' effect on the water table in the Beaumont Basin.

Another approach would be to apply the SWP water deliveries over a greater area along the southern side of the Cherry Valley region in additional recharge ponds. Construction of additional recharge ponds to the southeast of the current Noble Creek Recharge Project ponds would spread the volume of recharge over a wider area, creating a wider barrier to the movement of nitrate plumes into the southern Beaumont Basin. Additional recharge ponds could also 
dilute currently existing plumes just south of the Cherry Valley region, so that portions of the nitrate plumes that reach production wells would have a lower concentration. Assuming land is available to construct additional artificial recharge ponds, this alternative might be less costly than construction of a groundwater treatment facility.

\section{Model Limitations}

While this model has taken many variables into account that may affect the hydraulics of the Beaumont Basin, there are some areas where the model could use some improvement. The hydraulic conductivities assigned to the model are based on assumed grain sizes from drilling logs, which provided very qualitative descriptions of the soil during drilling. (See Hydraulic Conductivity on page 29) The number of drilling logs used to make an initial estimate of the conductivities was also limited to five drilling logs, and the spatial distribution of these logs was fairly linear, making it difficult to assume some of the aquifer properties on the far west side of the Beaumont Basin.

Within this report, there is very little data to help define the hydraulic properties of the perched aquifer area north of the Cherry Valley fault. While data from the study done by Flint and Ellet were used in this study, it is difficult to determine how soil properties within the Cherry Valley region relate to other soils throughout the entire extent of the Beaumont Basin. Since little data was available to describe the hydraulic conductivity within the Qo-aged layer of soil, it is possible that the hydraulic conductivity assigned to this layer of the model is quite a bit higher than in reality.

Another limitation is the accuracy of the concentration of nitrate coming 
into the model area from mountain front recharge. Along the northwestern boundary of the Beaumont Basin, a series of injection wells and nitrate point sources serve to model the inflow of groundwater along this northern boundary, as well as the inflow of nitrate from the hydraulic region to the north of the Beaumont Basin. While the USGS study (Rewis, et al. 2006) provides calibrated values for the mountain front recharge, and the UCR study (University of California, Riverside 2012) provides data on an approximate volume of nitrate that moves into the Beaumont Basin from mountain front recharge, the model developed in this study seems to leave some artifacts in the nitrate concentrations in the northwestern region of the Beaumont Basin.

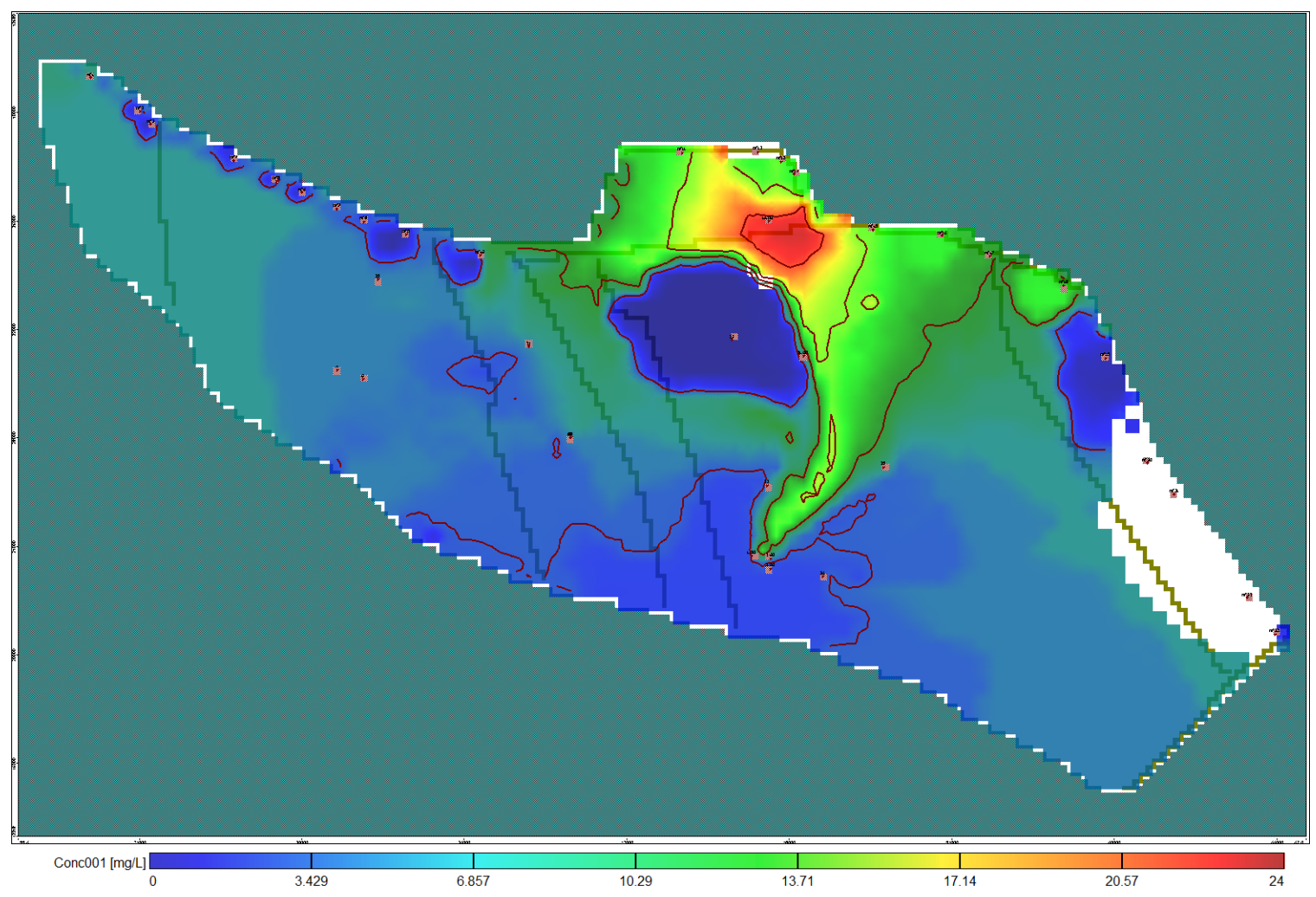

Figure 57: Nitrate (mg/L), no changes to pumping rates, Dec. 31, 2035

Over time, the model shows that the concentration of nitrate decreases around the injection points for mountain front recharge in the northwestern region 
of the basin. Figure 57 shows a version of the Beaumont Basin model developed in this study, where all pumping is assumed to be the same as the average pumping rate from June 2009 to May 2010, as if the populations of Beaumont and Cherry Valley did not increase, thus maintaining the current demand for groundwater for domestic use. Even without increased pumping in the southern Beaumont Basin, the developed model shows a decrease in nitrate concentration. This suggests that either the volume of mountain front recharge in the model is too high, and is effectively diluting nitrate in this part of the model, or the assumed concentrations of nitrate coming into the model at these points is lower than the concentrations in the field. Since there is limited data available for nitrate concentrations in this area of the model, it is difficult to be sure that the modeled mountain front recharge is accurately modeling nitrate plumes that enter the Beaumont Basin along the northern boundary.

\section{Suggestions for Future Work}

Future studies that build on this body of work should incorporate more comprehensive data for hydraulic conductivities throughout the Beaumont Basin. While the methods used within this study do provide some insights into the hydraulics of the aquifer and calculated heads are improved through calibration, more data concerning hydraulic conductivity for production and observation well sites would make the model more accurate, perhaps even before calibration. Since the Beaumont Basin consists of many layers of sedimentary deposits, it is difficult to assume properties for the entire extent of the basin, as it is very likely that hydraulic conductivity and porosity vary throughout the basin. With more information available regarding the properties of the aquifer, there is a better 
chance to enhance a model regarding the nitrate movement through the Beaumont Basin.

Additional field work includes more detailed studies of the nitrate concentrations within the Beaumont Basin. While the BCVWD did provide nitrate concentration data for this study, there are relatively few points within the Beaumont Basin where nitrate concentrations are known in this study. By taking more field measurements, both in the major production wells and in shallower private wells within the Cherry Valley region, a more accurate picture of the extent of nitrate movement may be determined in future studies.

Another possible area of improvement for this study is the calibration process. The hydraulic conductivity for the Beaumont Basin was divided into 10 hydraulic conductivity zones for each layer during calibration. Due to the many sediment layers within the Beaumont Basin, it is possible that increasing the number of conductivity zones may help to capture the variability of the soil properties more accurately. A few different methods of calibration exist for larger scale, complex problems. These include a subspace limited memory quasiNewton algorithm (Ni and Yuan 1997), which does not need to solve subproblems during optimization iterations, and a combination of a quasi-Newton and stochastic algorithm (Cekerevac, et al. 2006), which may be more suitable for finding the global minimum of a highly non-linear objective function. While these methods are not currently used in PEST for calibration with Visual MODFLOW, it may be possible, after future development, to use such methods with Visual MODFLOW data to calibrate a groundwater model. 


\section{Bibliography}

Agency, U.S. Environmental Protection. Nitrogen Cycle.jpg.

Arkyan. "Riverside County California Incorporated and Unincorporated areas

Beaumont Highlighted." Wikimedia Commons. 2007.

Bear, Jacob, and Arnold Verruijt. Modeling Groundwater Flow and Pollution.

Dordrecht: D. Reidel Publishing Company, 1987.

Beaumont-Cherry Valley Water District. "2006 Consumer Confidence Report." Beaumont, CA, 2007.

Beaumont-Cherry Valley Water District. "2007 Consumer Confidence Report." Beaumont, CA, 2008.

Beaumont-Cherry Valley Water District. "2008 Consumer Confidence Report." Beaumont, CA, 2009.

Beaumont-Cherry Valley Water District. "2009 Consumer Confidence Report." Beaumont, CA, 2010.

Beaumont-Cherry Valley Water District. 2010 Urban Water Management PlanDraft for Review. Beaumont-Cherry Valley Water District, 2011.

Beaumont-Cherry Valley Water District. "Annual Water Report: Water Testing Performed in 2010." Beuamont, CA, 2011.

-. Beaumont-Cherry Valley Water District. 2011. http://www.bcvwd.org/ (accessed December 13, 2011).

Beaumont-Cherry Valley Water District. "Well Data Sheets." 1995.

Cekerevac, C., S. Girardin, G. Klubertanz, and L. Laloui. "Calibration of an elasto-plastic constituitive model by a constrained optimisation procedure." Computers and Geotechnics, 2006: 432-443.

Davis, Jeff. "Email conversation." September 7, 2011.

Davis, Jeff, and Cheryle Rasmussen, interview by Jake M. Perry. (December 13, 2011).

De Weist, Roger J. M., ed. Flow Through Porous Media. New York: Academic Press, Inc., 1969.

Dutch, Steven. Converting UTM to Latitude and Longitude (Or Vice Versa). May 9, 2011. http://www.uwgb.edu/dutchs/usefuldata/utmformulas.htm (accessed November 1, 2011).

Esri. Measuring in Arc-Seconds. 2011. http://www.esri.com/news/arcuser/0400/wdside.html (accessed December 12, 2011).

Flint, Alan L., and Kevin M. Ellett. "The Role of the Unsaturated Zone in Artificial Recharge at San Gorgonio Pass, California." Vadose Zone Journal (Soil Science Society of America), no. 3 (2004): 763-774.

Harbaugh, A. W. MODFLOW-2005, the U.S. Geological Survey modular groundwater model--the Ground-Water Flow Process: U.S. Geological Survey Techniques and Methods 6-A16. Reston, Virginia: U.S. Geological Survey, 2005.

M, Uri. Diffusion coefficient of nitrate in water - Generic - BNID 104439. June 24, 2009.

http://bionumbers.hms.harvard.edu//bionumber.aspx?id=104439\&ver=2 
(accessed March 26, 2012).

National Geodetic Survey. Orthometric Height Conversion. 1999.

http://www.ngs.noaa.gov/cgi-bin/VERTCON/vert_con.prl (accessed

September 25, 2011).

Neider, R., and D. K. Benbi. Carbon and Nitrogen in the Terrestrial Environment. Springer Science and Business Media B.V., 2008.

$\mathrm{Ni}, \mathrm{Q}$., and Y. Yuan. "A subspace limited memory quasi-Newton algorithm for large-scale nonlinear bound constrained optimization." Mathematics of computation, 1997: 1509-1520.

Onboard Informatics. Cherry Valley, California (CA 92223) profile: population, maps, real estate, averages, homes, statistics, relocation, travel, jobs, hospitals, schools, crime, moving, houses, news, sex offenders. Advameg, Inc. 2011. http://www.city-data.com/city/Cherry-Valley-California.html (accessed 12 22, 2011).

Payne, William Jackson. Denitrification. New York: John Wiley \& Sons, Inc., 1981.

Reichenberger, Joseph. "Email Conversation." January 6, 2012.

Rewis, D.L., A.H. Christensen, J.C. Matti, J.A. Hevesi, Tracy Nishikawa, and Peter Martin. Geology, ground-water hydrology, geochemistry, and ground-water simulation of the Beaumont and Banning storage units, San Gorgonio Pass area, Riverside County, California: U.S. Geologic Survey Scientific Investigations Report 2006-5026. Reston, Virginia: U.S. Geological Survey, 2006, 173.

Riverside County Flood Control Department. Beuamont (013) Banning Bench (011) Cherry Valley (036) daily 1999 to 2011.txt. Prod. Steven Clark. December 14, 2011.

Schlumberger Water Services. Visual MODFLOW Dynamic Groundwater Flow and Contaminant Transport Software: User's Manual. PDF Document. Schlumberger Water Services. 2010.

Southern California Edison. "Agricultural and Pumping Rate Summary." Southern California Edison. 2010.

http://asset.sce.com/Documents/Customer\%20Service\%20\%20Rates/090128_Agriculture_Pumping_Rates.pdf (accessed September $28,2011)$.

Taylor, James R. "Evaluating Groundwater Nitrates from On-Lot Septic." Taylor Geoservices. 2003.

http://www.taylorgeoservices.com/papers/nitratereport.PDF (accessed February 21, 2012).

Tchobanoglous, George, and Edward D. Schroeder. Water Quality. Reading, Massachusetts: Addison-Wesley Publishing Company, 1985.

U.S. Environmental Protection Agency. "Effects of Nitrogen and Phosphorus Pollution| Nutrients| US EPA." US Environmental Protection Agency. December 21, 2011. http://water.epa.gov/scitech/swguidance/standards/criteria/nutrients/effect s.cfm (accessed December 22, 2011).

—. "Interactive Handbook for Managing Individual and Clustered (Decentralized) 
Wastewater Treatment Systems." US EPA. 2009. http://nepis.epa.gov/Adobe/PDF/P1004XER.PDF (accessed April 1, 2012).

—. "Onsite Water Treatment Systems Manual EPA/625/R-00/008 February 2002." US Environmental Protection Agency. 2002. http://www.epa.gov/nrmrl/pubs/625r00008/html/625R00008.htm (accessed $1214,2011)$.

—. "The Quality of Our Nation's Water: 1992." US EPA. 1992. http://water.epa.gov/lawsregs/guidance/cwa/305b/upload/2002_04_08_30 5b_92report_92summ.pdf (accessed April 10, 2012).

United States Geological Survey. Seamless Data Warehouse. December 28, 2010. http://seamless.usgs.gov/index.php (accessed September 29, 2011).

University of California, Riverside. "Water Quality Assesment of the Beaumont Management Zone: Identifying Sources of Groundwter Contamination Using Chemical and Isotopic Tracers." Engineering Report, Department of Environmental Sciences, Riverside, CA, 2012.

USGS. Groundwater levels -- 129 sites found. September 19, 2011. http://nwis.waterdata.usgs.gov/ca/nwis/gwlevels?nw_longitude_va $=117 \% 2$ $003 \& n w$ latitude_va $=34 \& s e$ longitude_va $=116 \% 2055 \&$ se_latitude_va $=33$ \%2054\&coordinate_format=dms\&format=station_list\&sort_key=site_no\&gr oup_key=NONE\&date_format=YYYY-MM-DD\&rdb_compression=fil (accessed September 2011, 2011).

-. "Groundwater Use, the USGS Water Science School." U.S. Geological Survey. December 22, 2011. http://ga.water.usgs.gov/edu/wugw.html (accessed January 8, 2012).

Watermark Numerical Computing. "PEST: Model-Independent Parameter Estimation, User Manual: 5th Edition." User Manual, 2010.

Wilfley, Bryan. "Email Conversation." February 27, 2009. 


\section{Appendix}

Table 13: Nitrate concentrations for Projected Alternatives

\begin{tabular}{|c|c|c|c|c|c|c|c|c|c|c|c|c|}
\hline \multicolumn{13}{|c|}{ General Forecast - 9371 Days } \\
\hline \multirow{2}{*}{ Date } & \multirow{2}{*}{$\begin{array}{l}\text { Model } \\
\text { Day }\end{array}$} & \multicolumn{11}{|c|}{ Concentration at each Production Well (mg/L), Layer 4} \\
\hline & & 1 & 2 & 3 & 16 & 21 & 22 & 23 & 24 & 25 & 26 & 29 \\
\hline $5 / 31 / 2010$ & 26.00 & 4.13 & 4.13 & 4.13 & 22.03 & 17.21 & 4.13 & 7.36 & 4.13 & 4.26 & 4.13 & 6.05 \\
\hline $11 / 30 / 2015$ & 2035.00 & 4.59 & 4.59 & 4.13 & 22.02 & 15.75 & 4.13 & 3.43 & 4.86 & 5.23 & 4.73 & 6.07 \\
\hline $2 / 28 / 2021$ & 3952.00 & 7.32 & 6.78 & 4.25 & 21.98 & 14.89 & 4.20 & 0.67 & 5.34 & 6.11 & 4.84 & 6.08 \\
\hline $12 / 31 / 2025$ & 5719.00 & 10.32 & 10.23 & 4.95 & 21.88 & 14.84 & 4.50 & 0.09 & 5.57 & 6.57 & 4.82 & 6.10 \\
\hline $12 / 31 / 2030$ & 7545.00 & 10.03 & 11.87 & 5.46 & 21.59 & 14.90 & 5.67 & 0.02 & 6.48 & 7.45 & 5.12 & 6.12 \\
\hline $12 / 31 / 2035$ & 9371.00 & 9.92 & 12.93 & 6.51 & 21.24 & 14.18 & 7.02 & 0.04 & 7.18 & 7.25 & 5.43 & 6.10 \\
\hline \multicolumn{13}{|c|}{ Alternative 1 - 9371 Days } \\
\hline \multirow[t]{2}{*}{ Date } & \multirow{2}{*}{$\begin{array}{l}\text { Model } \\
\text { Day }\end{array}$} & \multicolumn{11}{|c|}{ Concentration at each Product } \\
\hline & & 1 & 2 & 3 & 16 & 21 & 22 & 23 & 24 & 25 & 26 & 29 \\
\hline $5 / 31 / 2010$ & 26.00 & 3.94 & 3.94 & 4.00 & 22.11 & 17.28 & 3.95 & 7.46 & 4.26 & 4.60 & 4.21 & 6.21 \\
\hline $11 / 30 / 2015$ & 2035.00 & 4.59 & 4.57 & 4.06 & 22.18 & 15.85 & 4.01 & 5.03 & 4.88 & 5.36 & 4.68 & 6.26 \\
\hline $2 / 28 / 2021$ & 3952.00 & 6.55 & 5.90 & 4.19 & 22.00 & 15.24 & 4.13 & 1.86 & 5.33 & 5.73 & 4.97 & 6.29 \\
\hline $12 / 31 / 2025$ & 5719.00 & 8.23 & 8.01 & 5.26 & 21.76 & 15.02 & 4.61 & 0.42 & 5.74 & 6.44 & 5.20 & 6.28 \\
\hline $12 / 31 / 2030$ & 7545.00 & 8.44 & 10.94 & 5.77 & 21.63 & 15.20 & 5.66 & 0.25 & 6.53 & 6.93 & 5.27 & 6.32 \\
\hline $12 / 31 / 2035$ & 9371.00 & 8.87 & \begin{tabular}{|l|}
12.37 \\
\end{tabular} & 5.73 & 21.24 & 15.66 & 8.02 & 0.13 & 7.02 & 6.75 & 5.42 & 6.33 \\
\hline \multicolumn{13}{|c|}{ Alternative 2 - 9371 Days } \\
\hline \multirow[t]{2}{*}{ Date } & \multirow{2}{*}{$\begin{array}{c}\text { Model } \\
\text { Day }\end{array}$} & \multicolumn{11}{|c|}{ Concentration at each Produc } \\
\hline & & 1 & 2 & 3 & 16 & 21 & 22 & 23 & 24 & 25 & 26 & 29 \\
\hline $5 / 31 / 2010$ & 26.00 & 4.13 & 4.13 & 4.13 & 22.03 & 17.21 & 4.13 & 7.40 & 4.13 & 4.26 & 4.13 & 6.05 \\
\hline $11 / 30 / 2015$ & 2035.00 & 4.77 & 4.71 & 4.13 & 22.02 & 15.53 & 4.13 & 1.07 & 4.83 & 5.38 & 4.61 & 6.07 \\
\hline $9 / 30 / 2021$ & 4166.00 & 8.21 & 7.29 & 4.38 & 21.97 & 14.25 & 4.26 & 0.03 & 5.46 & 6.75 & 4.81 & 6.08 \\
\hline $11 / 30 / 2025$ & 5688.00 & 11.94 & 11.02 & 5.50 & 21.93 & 13.89 & 4.74 & 0.01 & 5.86 & 7.53 & 4.72 & 6.11 \\
\hline $11 / 30 / 2030$ & 7514.00 & 9.92 & 12.84 & 5.74 & 21.69 & 8.24 & 5.87 & 0.02 & 6.57 & 8.89 & 5.02 & 6.11 \\
\hline $2 / 28 / 2035$ & 9065.00 & 8.09 & 12.27 & 6.02 & 21.35 & 1.90 & 7.49 & 0.01 & 7.07 & 9.03 & 5.32 & 6.10 \\
\hline \multicolumn{13}{|c|}{ Alternative 3- 9371 Days } \\
\hline \multirow[t]{2}{*}{ Date } & \multirow{2}{*}{$\begin{array}{c}\text { Model } \\
\text { Day }\end{array}$} & \multicolumn{11}{|c|}{ Concentration at each Producti } \\
\hline & & 1 & 2 & 3 & 16 & 21 & 22 & 23 & 24 & 25 & 26 & 29 \\
\hline $5 / 31 / 2010$ & 26.00 & 3.94 & 3.94 & 4.00 & 22.13 & 17.27 & 3.94 & 7.49 & 4.26 & 4.61 & 4.22 & 6.21 \\
\hline $10 / 31 / 2015$ & 2005.00 & 4.62 & 4.57 & 4.06 & 21.19 & 15.84 & 4.03 & 3.57 & 4.82 & 5.29 & 4.63 & 6.24 \\
\hline $2 / 28 / 2021$ & 3952.00 & 6.39 & 6.22 & 4.26 & 19.84 & 15.21 & 4.16 & 1.32 & 5.29 & 5.83 & 4.95 & 6.27 \\
\hline $12 / 31 / 2025$ & 5719.00 & 8.52 & 8.46 & 4.56 & 18.97 & 15.04 & 4.51 & 0.40 & 5.77 & 6.30 & 5.16 & 6.29 \\
\hline $12 / 31 / 2030$ & 7545.00 & 9.47 & 10.61 & 5.90 & 17.70 & 15.09 & 5.60 & 0.06 & 6.13 & 6.88 & 5.27 & 6.30 \\
\hline 9/30/2032 & 8184.00 & 9.59 & 11.58 & 5.27 & 17.63 & 15.04 & 6.08 & 0.07 & 6.68 & 6.98 & 5.24 & 6.31 \\
\hline
\end{tabular}




\begin{tabular}{|c|c|c|c|c|c|c|c|c|c|c|c|c|}
\hline \multicolumn{13}{|c|}{ Alternative 4 - 9371 Days } \\
\hline \multirow[t]{2}{*}{ Date } & \multirow{2}{*}{$\begin{array}{c}\text { Model } \\
\text { Day }\end{array}$} & \multicolumn{11}{|c|}{ Concentration at each Production Well (mg/L), Layer 4} \\
\hline & & 1 & 2 & 3 & 16 & 21 & 22 & 23 & 24 & 25 & 26 & 29 \\
\hline $5 / 31 / 2010$ & 26.00 & 3.94 & 3.94 & 4.00 & 22.11 & 17.26 & 3.94 & 7.49 & 4.26 & 4.61 & 4.22 & 6.21 \\
\hline $11 / 30 / 2015$ & 2035.00 & 4.44 & 4.49 & 4.05 & 22.14 & 14.81 & 4.03 & 1.52 & 4.87 & 5.23 & 4.75 & 6.25 \\
\hline $9 / 30 / 2021$ & 4166.00 & 5.35 & 5.56 & 4.27 & 21.93 & 12.75 & 4.16 & 0.21 & 5.38 & 5.53 & 4.99 & 6.26 \\
\hline $11 / 30 / 2025$ & 5688.00 & 6.31 & 6.65 & 4.44 & 21.73 & 12.19 & 4.39 & 0.05 & 5.72 & 5.88 & 5.19 & 6.28 \\
\hline $11 / 30 / 2030$ & 7514.00 & 6.94 & 8.43 & 5.47 & 21.48 & 7.03 & 5.14 & 0.02 & 6.36 & 6.22 & 5.28 & 6.31 \\
\hline $2 / 28 / 2035$ & 9065.00 & 7.14 & 9.41 & 5.07 & 21.29 & 6.76 & 6.57 & 0.02 & 6.56 & 6.35 & 5.28 & 6.28 \\
\hline \multicolumn{13}{|c|}{ Alternative 5 - 9371 Days } \\
\hline \multirow[t]{2}{*}{ Date } & \multirow{2}{*}{$\begin{array}{c}\text { Model } \\
\text { Day }\end{array}$} & \multicolumn{11}{|c|}{ Concentration at each Production Well (mg/L), Layer 4} \\
\hline & & 1 & 2 & 3 & 16 & 21 & 22 & 23 & 24 & 25 & 26 & 29 \\
\hline $5 / 31 / 2010$ & 26.00 & 3.94 & 3.94 & 4.00 & 22.13 & 17.26 & 3.94 & 7.49 & 4.26 & 4.61 & 4.22 & 6.21 \\
\hline $11 / 30 / 2015$ & 2035.00 & 4.40 & 4.50 & 4.07 & 21.17 & 15.13 & 4.04 & 2.15 & 4.84 & 5.19 & 4.75 & 6.25 \\
\hline $9 / 30 / 2021$ & 4166.00 & 5.25 & 5.60 & 4.29 & 19.14 & 13.32 & 4.14 & 0.27 & 5.38 & 5.53 & 4.99 & 6.27 \\
\hline $11 / 30 / 2025$ & 5688.00 & 5.67 & 6.40 & 4.49 & 18.74 & 15.54 & 4.36 & 0.05 & 5.53 & 5.77 & 5.24 & 6.28 \\
\hline $11 / 30 / 2030$ & 7514.00 & 5.90 & 7.05 & 4.81 & 17.67 & 8.15 & 4.84 & 0.02 & 5.94 & 6.09 & 5.19 & 6.29 \\
\hline $2 / 28 / 2035$ & 9065.00 & 6.02 & 8.14 & 5.02 & 16.74 & 6.75 & 5.73 & 0.04 & 6.37 & 6.19 & 5.37 & 6.27 \\
\hline \multicolumn{13}{|c|}{ Alternative 6 - 9371 Days } \\
\hline \multirow[t]{2}{*}{ Date } & Model & \multicolumn{11}{|c|}{ Concentration at each Production Well (mg/L), Layer 4} \\
\hline & Day & 1 & 2 & 3 & 16 & 21 & 22 & 23 & 24 & 25 & 26 & 29 \\
\hline $5 / 31 / 2010$ & 26.00 & 4.13 & 4.13 & 4.13 & 22.03 & 17.21 & 4.13 & 7.36 & 4.13 & 4.25 & 4.13 & 6.05 \\
\hline $11 / 30 / 2015$ & 2035.00 & 4.41 & 4.38 & 4.13 & 21.10 & 15.09 & 4.13 & 3.98 & 4.76 & 5.20 & 4.78 & 6.07 \\
\hline $9 / 30 / 2021$ & 4166.00 & 5.24 & 5.34 & 4.17 & 19.20 & 13.88 & 4.17 & 1.21 & 5.34 & 5.40 & 4.86 & 6.08 \\
\hline $11 / 30 / 2025$ & 5688.00 & 5.40 & 5.86 & 4.34 & 18.47 & 13.50 & 4.27 & 0.34 & 5.43 & 5.75 & 5.02 & 6.08 \\
\hline $11 / 30 / 2030$ & 7514.00 & 5.37 & 6.32 & 4.74 & 17.31 & 11.96 & 4.71 & 0.03 & 6.07 & 5.99 & 5.35 & 6.08 \\
\hline $2 / 28 / 2035$ & 9065.00 & 5.77 & 7.18 & 4.67 & 16.61 & 9.92 & 5.17 & 0.04 & 6.23 & 6.22 & 5.42 & 6.05 \\
\hline \multicolumn{13}{|c|}{ Alternative 7 - 9371 Days } \\
\hline \multirow[t]{2}{*}{ Date } & Model & \multicolumn{11}{|c|}{ Concentration at each Product } \\
\hline & & 1 & 2 & 3 & 16 & 21 & 22 & 23 & 24 & 25 & 26 & 29 \\
\hline $5 / 31 / 2010$ & 26.00 & 4.13 & 4.13 & 4.13 & 22.03 & 17.21 & 4.13 & 7.36 & 4.13 & 4.25 & 4.13 & 6.05 \\
\hline $11 / 30 / 2015$ & 2035.00 & 4.36 & 4.43 & 4.13 & 22.02 & 15.18 & 4.13 & 3.51 & 4.71 & 5.18 & 4.80 & 6.08 \\
\hline $9 / 30 / 2021$ & 4166.00 & 5.25 & 5.36 & 4.18 & 21.95 & 13.81 & 4.18 & 0.56 & 5.28 & 5.40 & 4.81 & 6.08 \\
\hline $11 / 30 / 2025$ & 5688.00 & 5.28 & 5.91 & 4.30 & 21.82 & 12.98 & 4.27 & 0.21 & 5.51 & 5.72 & 5.00 & 6.09 \\
\hline $11 / 30 / 2030$ & 7514.00 & 5.82 & 7.59 & 4.85 & 21.42 & 10.96 & 4.75 & 0.09 & 6.16 & 6.01 & 5.32 & 6.07 \\
\hline 2/28/2035 & 9065.00 & 5.77 & 8.06 & 5.06 & 21.23 & 8.36 & 5.67 & 0.02 & 6.45 & 6.26 & 5.62 & 6.03 \\
\hline
\end{tabular}




\begin{tabular}{|c|c|c|c|c|c|c|c|c|c|c|c|c|}
\hline \multicolumn{13}{|c|}{ Alternative 8 - 9371 Days } \\
\hline \multirow[t]{2}{*}{ Date } & \multirow{2}{*}{$\begin{array}{l}\text { Model } \\
\text { Day }\end{array}$} & \multicolumn{11}{|c|}{ Concentration at each Production Well (mg/L), Layer 4} \\
\hline & & 1 & 2 & 3 & 16 & 21 & 22 & 23 & 24 & 25 & 26 & 29 \\
\hline $5 / 31 / 2010$ & 26.00 & 3.94 & 3.94 & 4.00 & 22.13 & 17.27 & 3.94 & 7.47 & 4.26 & 4.61 & 4.22 & 6.21 \\
\hline $10 / 31 / 2015$ & 2005.00 & 4.63 & 4.53 & 4.07 & 21.19 & 15.93 & 4.03 & 5.81 & 4.79 & 5.26 & 4.70 & 6.24 \\
\hline $2 / 28 / 2021$ & 3952.00 & 6.04 & 6.06 & 4.27 & 19.48 & 15.43 & 4.15 & 2.67 & 5.32 & 5.72 & 4.92 & 6.27 \\
\hline $12 / 31 / 2025$ & 5719.00 & 8.06 & 7.42 & 4.91 & 18.71 & 15.19 & 4.45 & 1.15 & 5.65 & 6.04 & 5.12 & 6.29 \\
\hline $12 / 31 / 2030$ & 7545.00 & 7.15 & 10.42 & 5.56 & 17.98 & 15.09 & 5.46 & 0.62 & 6.23 & 6.37 & 5.26 & 6.27 \\
\hline 9/30/2032 & 8184.00 & 8.15 & 9.93 & 5.59 & 17.59 & 15.13 & 5.66 & 0.19 & 6.20 & 6.39 & 5.32 & 6.30 \\
\hline \multicolumn{13}{|c|}{ Recharge Alternative 1 - 9371 Days } \\
\hline \multirow[t]{2}{*}{ Date } & \multirow{2}{*}{$\begin{array}{c}\text { Model } \\
\text { Day }\end{array}$} & \multicolumn{11}{|c|}{ Concentration at each Production Well $(\mathrm{mg} / \mathrm{L})$, Layer 4} \\
\hline & & 1 & 2 & 3 & 16 & 21 & 22 & 23 & 24 & 25 & 26 & 29 \\
\hline $5 / 31 / 2010$ & 26.00 & 4.13 & 4.13 & 4.13 & 22.03 & 17.21 & 4.13 & 7.36 & 4.13 & 4.26 & 4.13 & 6.05 \\
\hline $11 / 30 / 2015$ & 2035.00 & 4.70 & 4.51 & 4.13 & 22.02 & 15.87 & 4.13 & 5.31 & 4.86 & 5.28 & 4.74 & 6.07 \\
\hline 2/28/2021 & 3952.00 & 7.02 & 6.51 & 4.30 & 21.98 & 15.50 & 4.21 & 2.57 & 5.30 & 6.19 & 4.85 & 6.08 \\
\hline $12 / 31 / 2025$ & 5719.00 & 10.20 & 9.84 & 4.86 & 21.88 & 15.09 & 4.52 & 1.59 & 5.71 & 6.80 & 4.87 & 6.10 \\
\hline $12 / 31 / 2030$ & 7545.00 & 9.05 & 9.68 & 5.12 & 21.60 & 14.98 & 5.94 & 0.31 & 6.44 & 7.38 & 5.10 & 6.14 \\
\hline $12 / 31 / 2035$ & 9371.00 & 7.59 & 7.75 & 5.10 & 21.24 & 15.14 & 8.51 & 0.13 & 7.26 & 7.73 & 5.44 & 6.10 \\
\hline \multicolumn{13}{|c|}{ Recharge Alternative 2 - 9371 Days } \\
\hline \multirow[t]{2}{*}{ Date } & \multirow{2}{*}{$\begin{array}{l}\text { Model } \\
\text { Day }\end{array}$} & \multicolumn{11}{|c|}{ Concentration at each Production Well (mg/L), Layer 4} \\
\hline & & 1 & 2 & 3 & 16 & 21 & 22 & 23 & 24 & 25 & 26 & 29 \\
\hline $5 / 31 / 2010$ & 26.00 & 4.13 & 4.13 & 4.13 & 22.03 & 17.21 & 4.13 & 7.33 & 4.13 & 4.30 & 4.13 & 6.05 \\
\hline $11 / 30 / 2015$ & 2035.00 & 4.69 & 4.56 & 4.13 & 22.02 & 15.94 & 4.13 & 6.88 & 4.83 & 5.21 & 4.65 & 6.07 \\
\hline $2 / 28 / 2021$ & 3952.00 & 6.31 & 5.89 & 4.26 & 21.97 & 16.63 & 4.22 & 4.23 & 5.23 & 6.09 & 4.85 & 6.07 \\
\hline $12 / 31 / 2025$ & 5719.00 & 4.69 & 3.85 & 4.38 & 21.88 & 15.39 & 4.59 & 3.25 & 6.56 & 6.75 & 4.75 & 6.10 \\
\hline $12 / 31 / 2030$ & 7545.00 & 4.81 & 3.01 & 4.35 & 21.57 & 15.02 & 6.01 & 1.55 & 6.18 & 7.66 & 5.12 & 6.10 \\
\hline $12 / 31 / 2035$ & 9371.00 & 5.36 & 3.25 & 4.45 & 21.26 & 15.03 & 6.36 & 1.12 & 6.87 & 7.56 & 5.41 & 6.07 \\
\hline
\end{tabular}




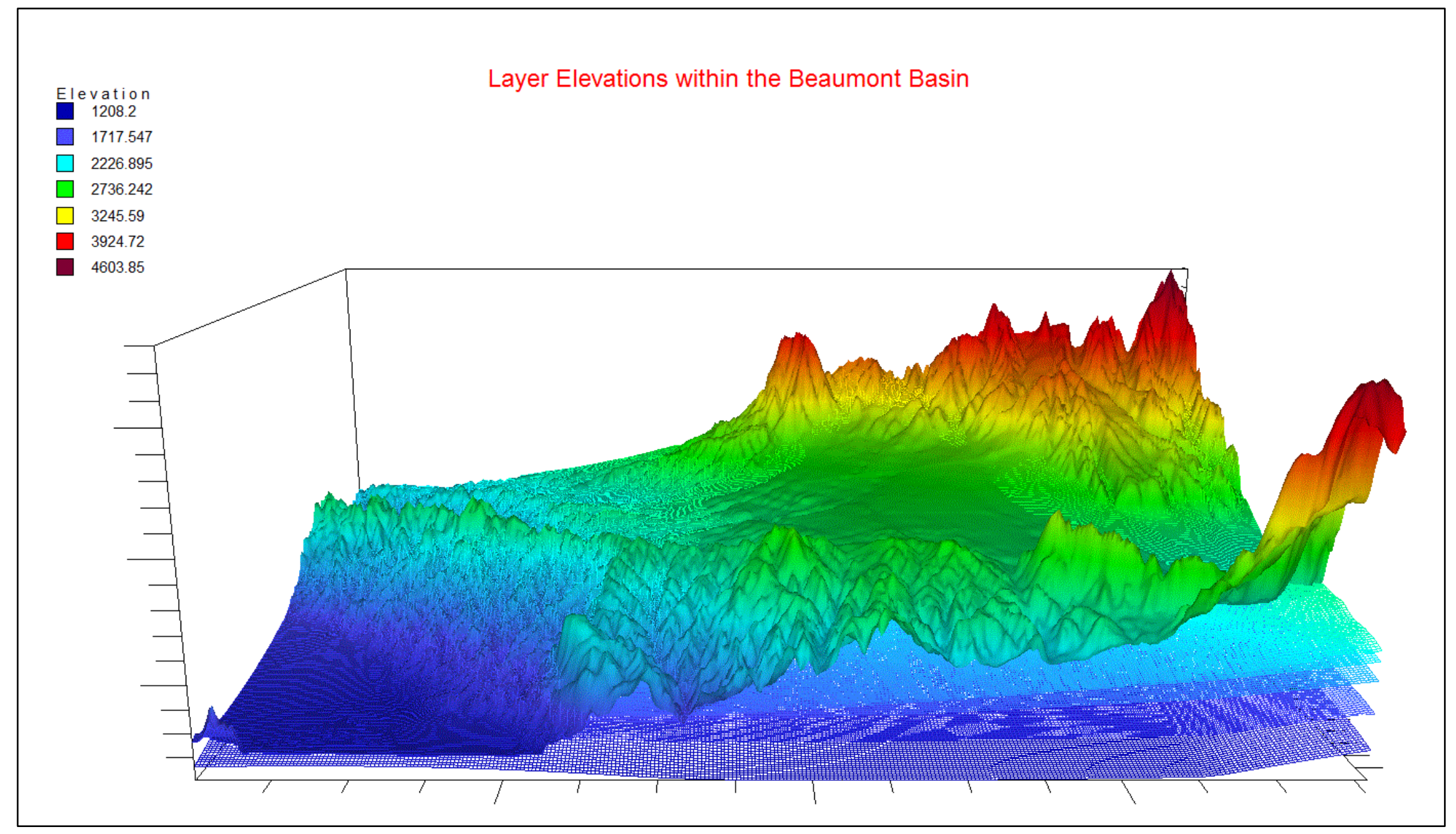

Figure 58: Layer Elevations in the Beaumont Basin, view from South to North 


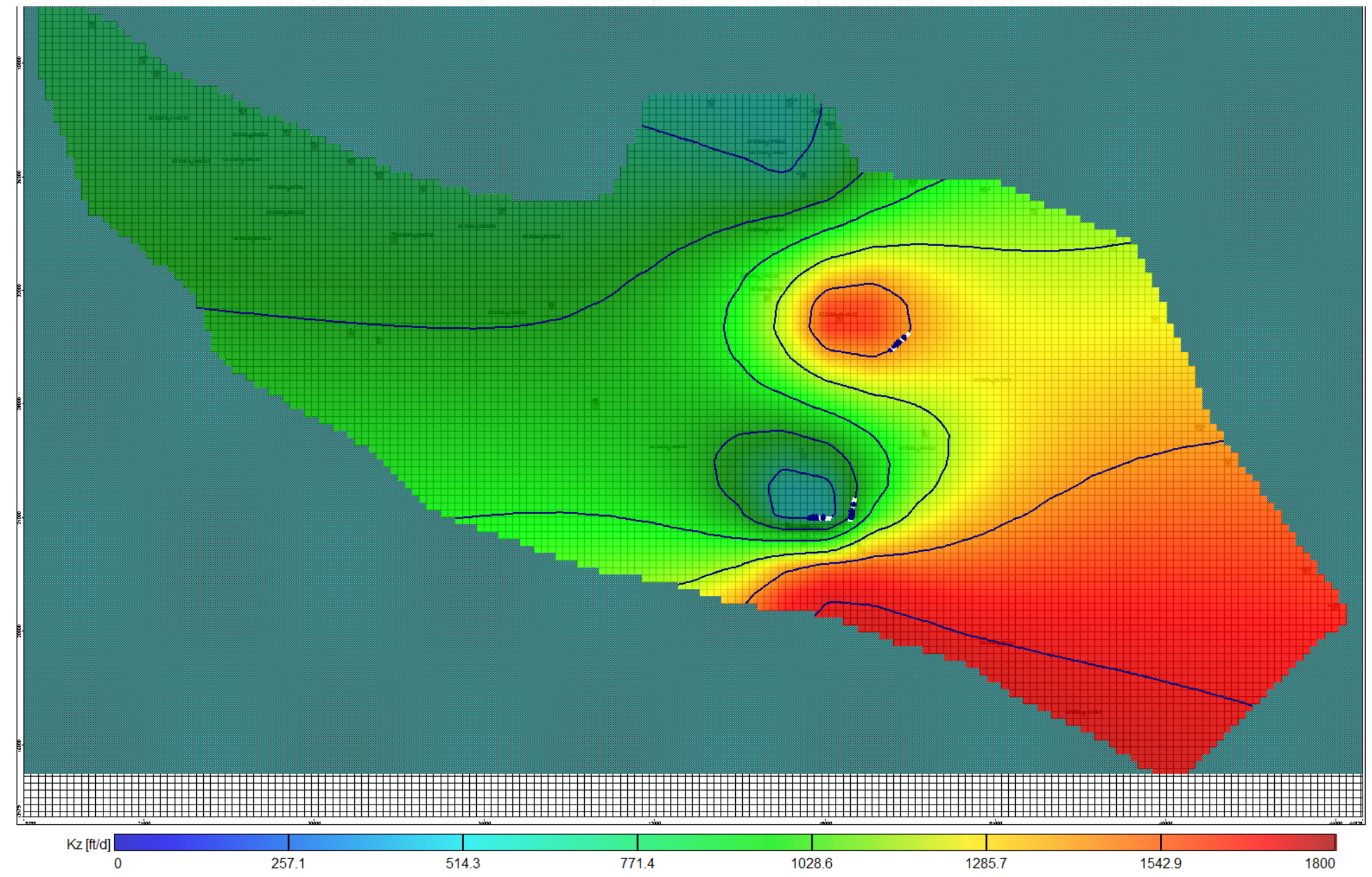

Figure 59: Vertical hydraulic conductivity, layer 1 


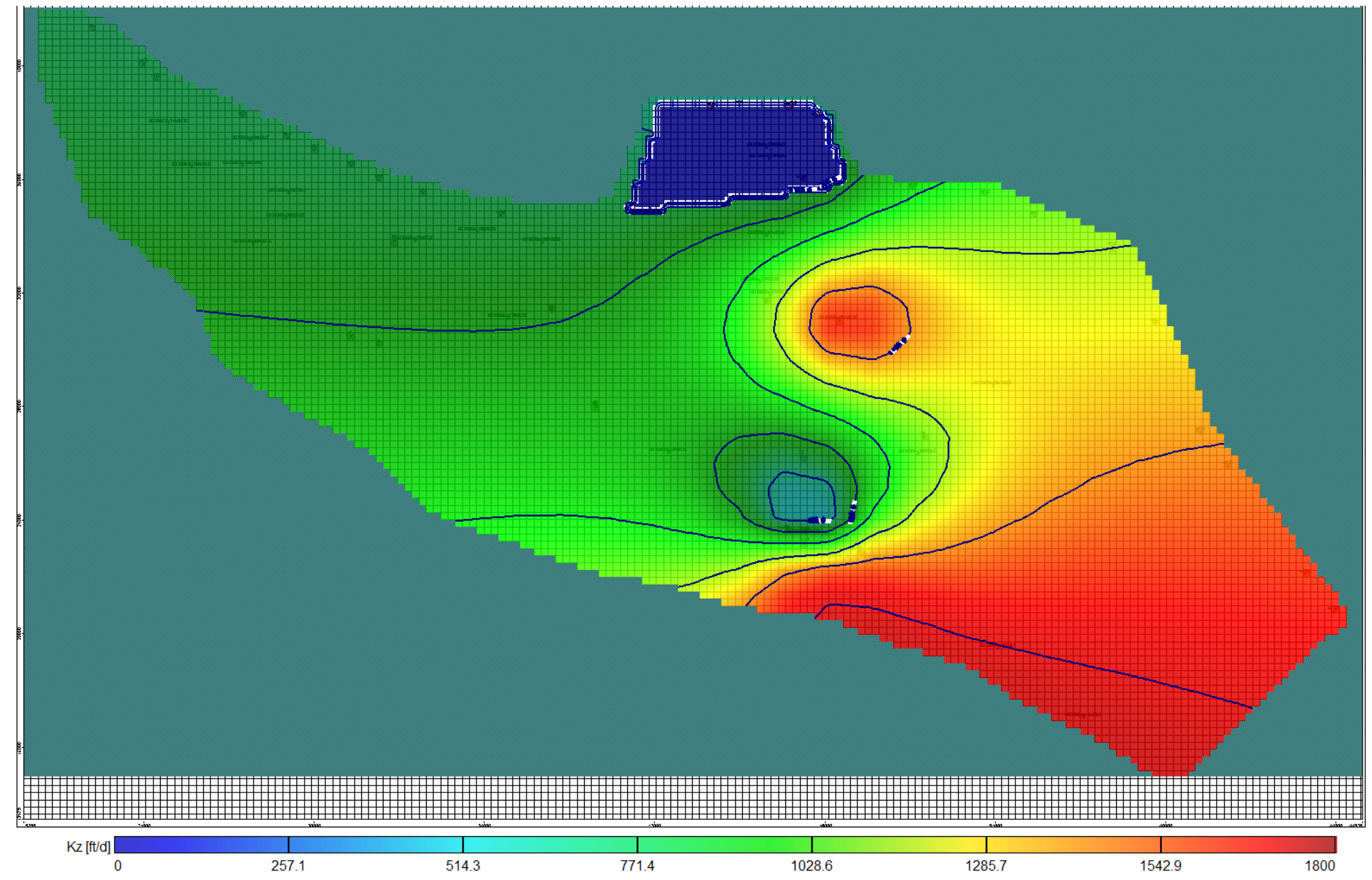

Figure 60: Vertical hydraulic conductivity, layer 2 


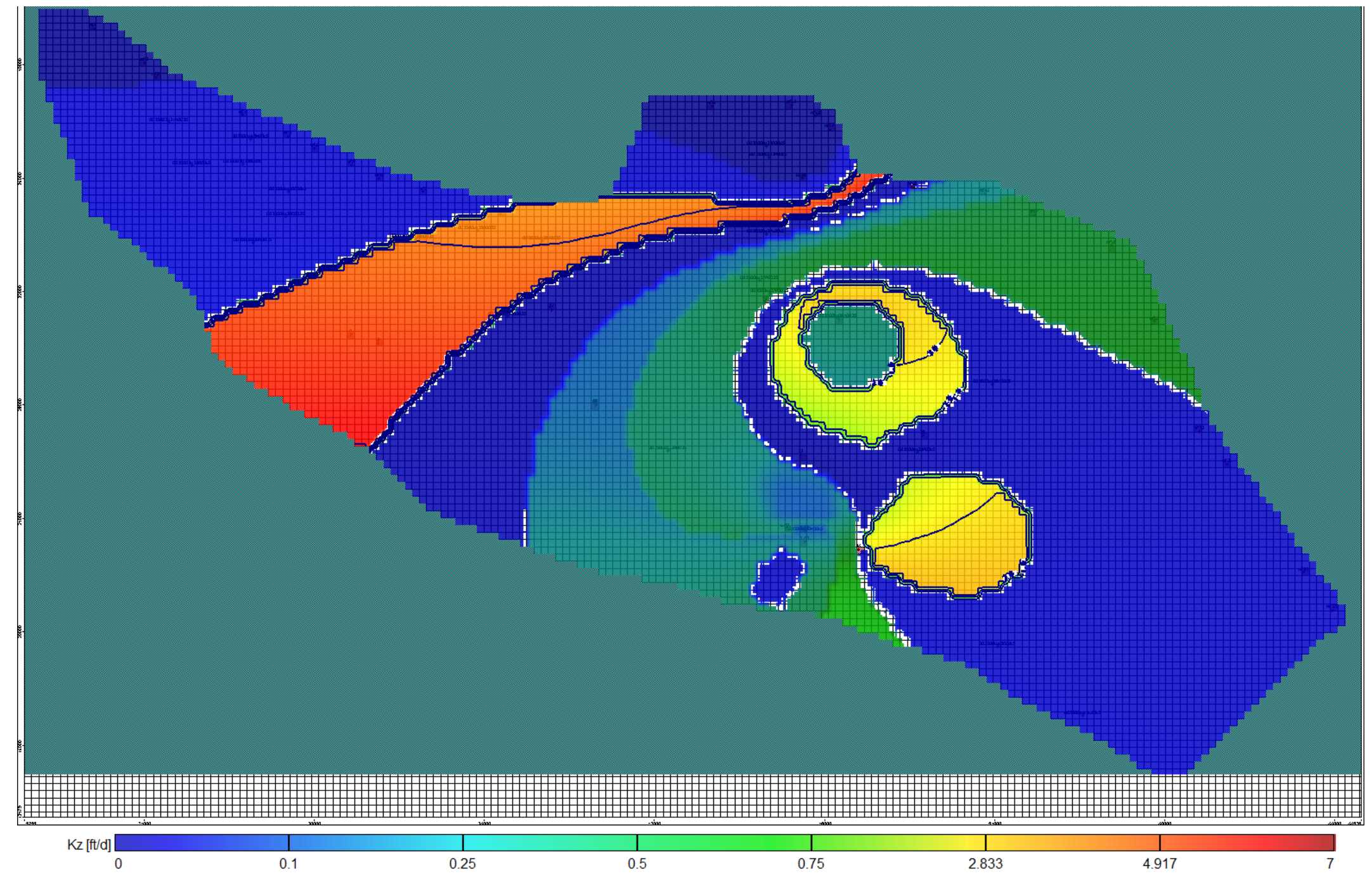

Figure 61: Vertical hydraulic conductivity, layer 3 


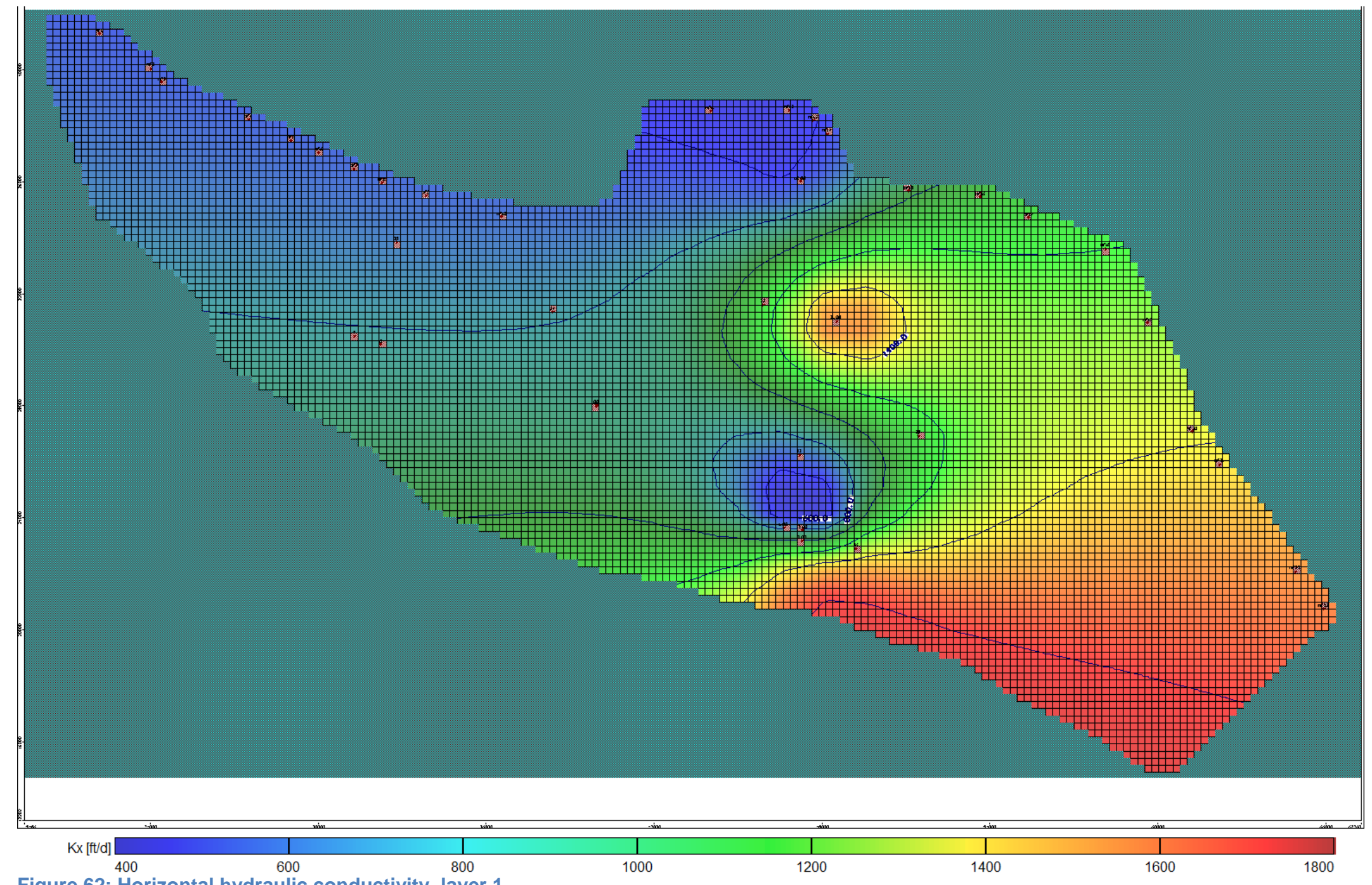




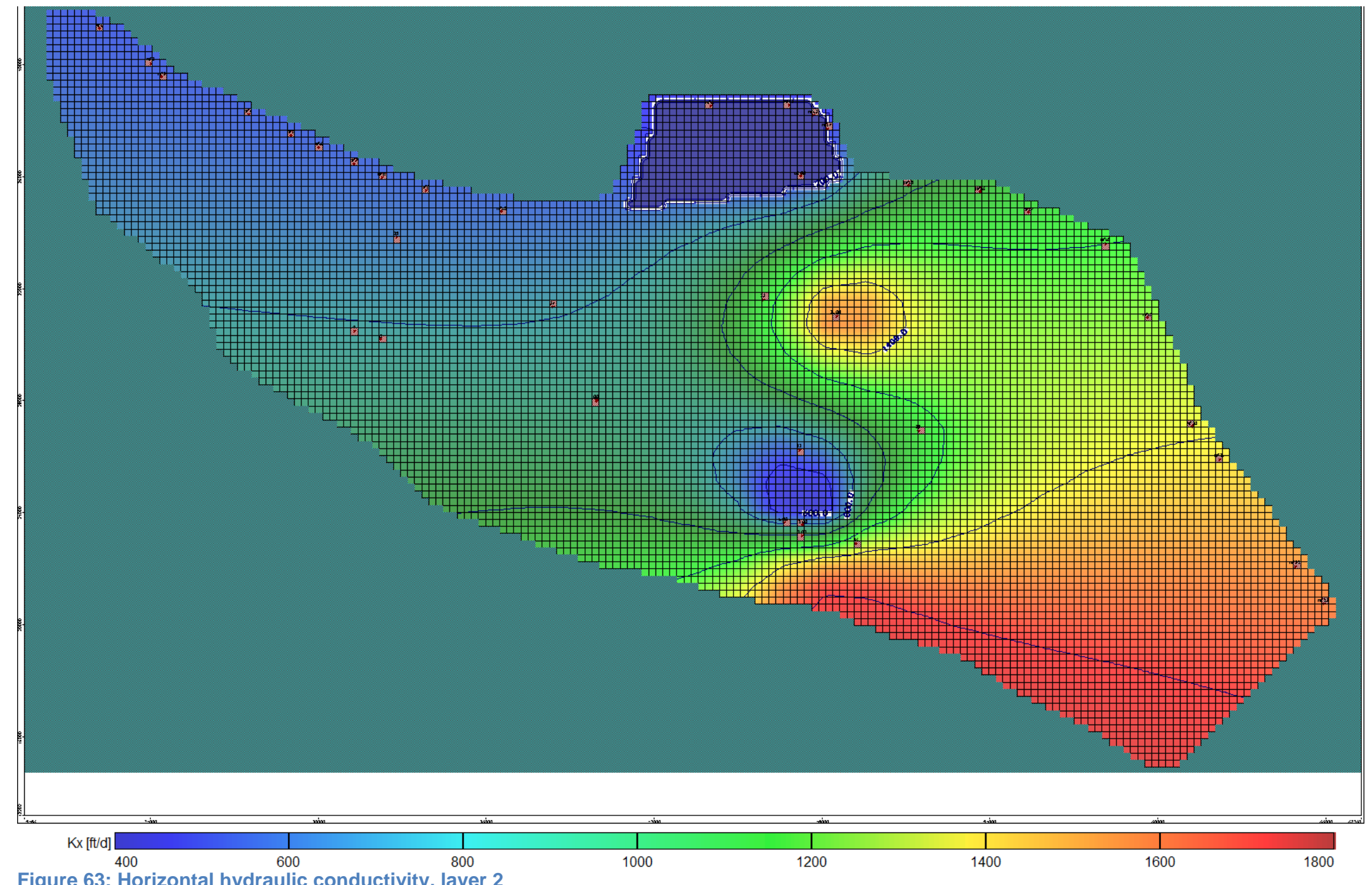




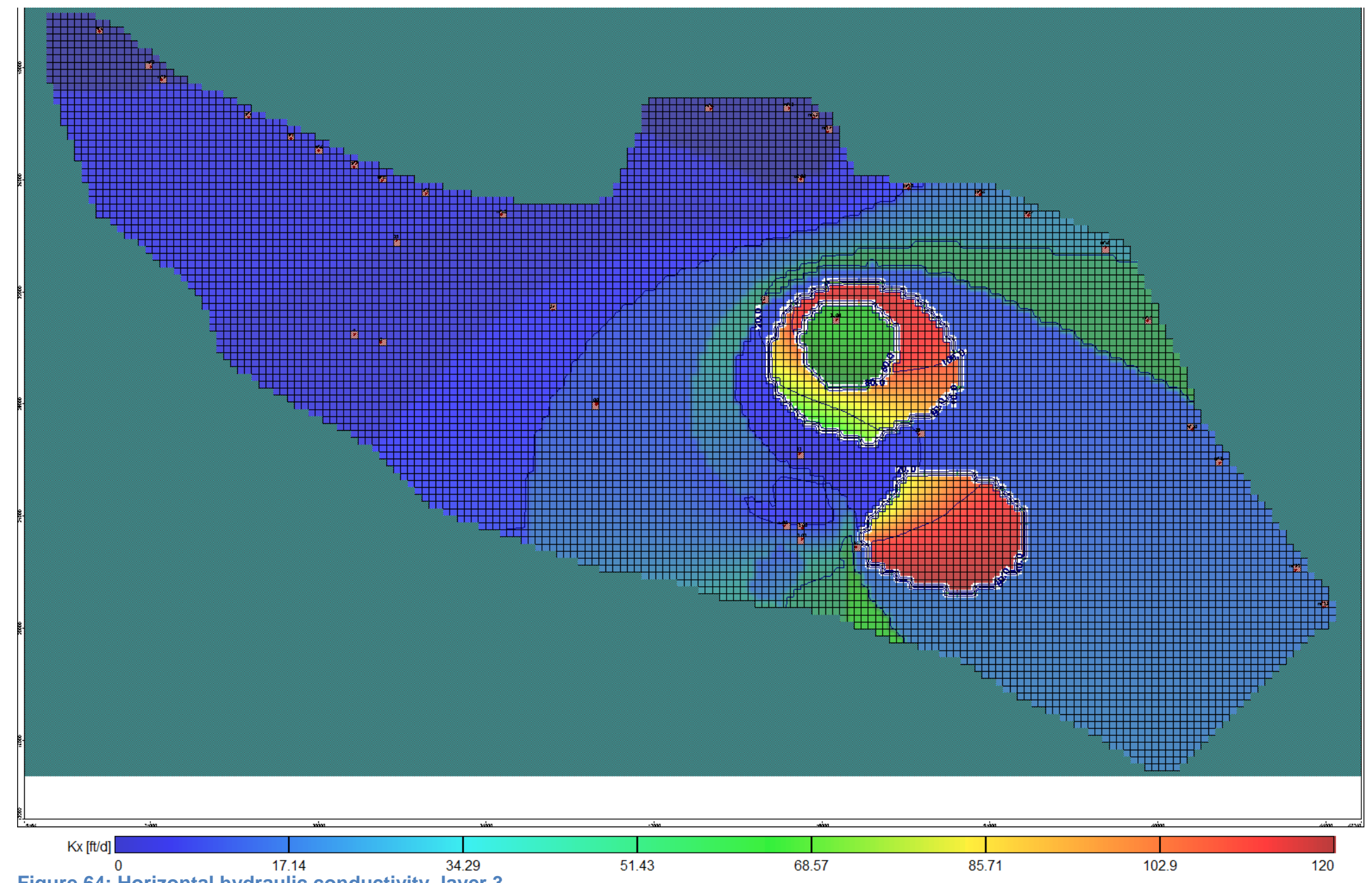

